PNL-4463

NUREG/CR-2946

PNL-4463

\title{
The Long Term Stability of Earthen Materials in Contact With Acidic Tailings Solutions
}

Prepared by S. R. Peterson, R. L. Erikson, G. W. Gee

Pacific Northwest Laboratory

Operated by

Battelle Memorial Institute

Prepared for

U.S. Nuclear Regulatory

Commission 


\section{NOTICE}

This report was prepared as an account of work sponsored by an agency of the United States Government. Neither the United States Government nor any agency thereof, or any of their employees, makes any warranty, expressed or implied, or assumes any legal liability of responsibility for any third party's use, or the results of such use, of any information, apparatus, product or process disclosed in this report, or represents that its use by such third party would not infringe privately owned rights.

\section{Availability of Reference Materials Cited in NRC Publications}

Most documents cited in NRC publications will be available from one of the following sources:

1. The NRC Public Document Room, 1717 H Street, N.W. Washington, DC 20555

2. The NRC/GPO Sales Program, U.S. Nuclear Regulatory Commission, Washington, DC 20555

3. The National Technical Information Service, Springfield, VA 22161

Although the listing that follows represents the majority of documents cited in NRC publications, it is not intended to be exhaustive.

Referenced documents available for inspection and copying for a fee from the NRC Public Document Room include NRC correspondence and ir.ternal NRC memoranda; NRC Office of Inspection and Enforcement bulletins, circulars, information notices, inspection and investigation notices; Licensee Event Reports; vendor reports and correspondence; Commission papers; and applicant and licensee documents and correspondence.

The following documents in the NUREG series are available for purchase from the NRC/GPO Sales Program: formal NRC staff and contractor reports, NRC-sponsored conference proceedings, and NRC booklets and brochures. Also available are Regulatory Guides, NRC regulations in the Code of Federal Regulations, and Nuclear Regulatory Commission /ssuances.

Documents available from the National Technical Information Service include NUREG series reports and technical reports prepared by other federal agencies and reports prepared by the Atomic Energy Commission, forerunner agency to the Nuclear Regulatory Commission.

Documents available fram public and special technical libraries include all open literature items, such as books, journal and periodical articles, and transactions. Federal Register notices, federal and state legisiation, and congressional reports can usually be abtained from these libraries.

Documents such as theses, dissertations, foreign reports and translations, and non-NRC conference proceedings are available for purchase trom the organization sponsoring the publication cited.

Single copies of NRC draft reports are available free upon written request to the Division of Technical Information and Document Control, U.S. Nuclear Regulatory Commission, Washington, DC 20555

Copies of industry codes and standards used in a substantive manner in the NRC regulatory process are maintained at the NAC Library, 7920 Norfolk Avenue, Bethesda, Maryland, and are available there for reference use by the public. Codes and standards are usually copyrighted and may be purchased from the originating organization or, if they are American National Standards, from the American National Standards Institute, 1430 Broadway, New York, NY 10018. 
NUREG/CR-2946

PNL-4463

$\mathrm{RU}$

\section{The Long Term Stability of Earthen Materials in Contact With Acidic Tailings Solutions}

Manuscript Completed: October 1982

Date Published: November 1982

Prepared by

S. R. Peterson, R. L. Erikson, G. W. Gee

Pacific Northwest Laboratory

Richland, WA 99352

Prepared for

Division of Health, Siting and Waste Management

Office of Nuclear Regulatory Research

U.S. Nuclear Regulatory Commission

Washington, D.C. 20555

NRC FIN B2292 


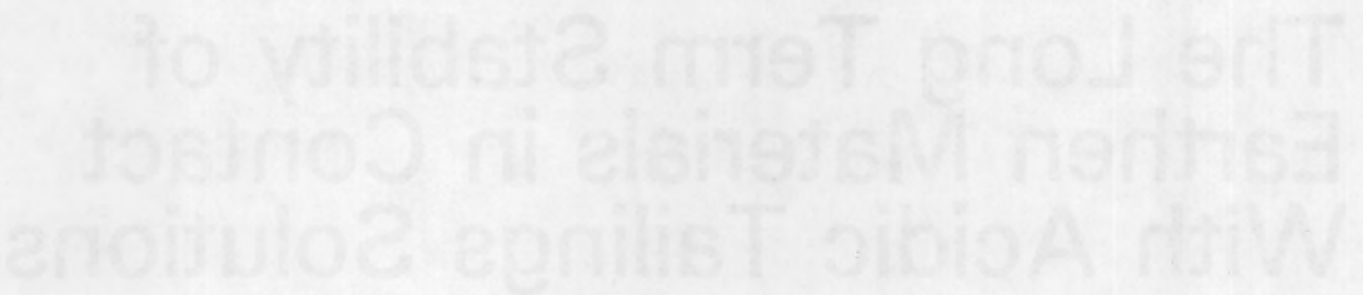




\section{EXECUTIVE SUMMARY}

The objectives of the studies documented in this report were to develop experimental and geochemical computer modeling tools to assess the long-term environmental impact of leachate movement from acidic uranium mill tailings. Laboratory experiments were designed to evaluate the migration potential of selected contaminants (both radioactive and toxic elements) from tailings leachate in contact with sediments and geologic liner materials. These laboratory experiments involved studying the physical, chemical, and mineralogical changes that take place when various sediments and clay liners are contacted with acidic tailings solutions in batch and column experiments. Special attention was placed on evaluating the effects of acid attack on clay liners to estimate long-term changes in mineralogy and hydraulic conductivity. The results from the laboratory experiments were then compared to selected field studies and geochemical modeling predictions.

Liner failure (i.e., an increase in the permeability of the liner material) was not found to be a problem when various acidic tailings solutions leached through liner materiais for periods up to 3 years. On the contrary, materials that contained over $30 \%$ clay showed a decrease in permeability with time in the laboratory columns. The high clay materials tested appear suitable for lining tailings impoundment ponds. The Morton Ranch clay liner, a silty clay loam, decreased in permeability from $1 / 2$ to over 2 orders of magnitude depending upon the given column and contacting solution. The final permeability of the Lucky Mc overburden, a silty clay, was $\sim 1 / 2$ the permeability observed at the beginning of the experiment. Even some soils, such as the Dawn overburden (a sandy loam), that contained less clay $(\sim 7 \%)$ showed decreases in permeability. Only the Morton Ranch overburden, a sandy loam with $\sim 9 \%$ clay and little carbonate $(\sim 0.2 \%)$, exhibited an increase in permeability over the time span of the study.

The decreases in permeability noted above are attributed to pore plugging resulting from the precipitation of minerals and solids. This precipitation takes place due to the increase in $\mathrm{pH}$ of the tailings solution brought about by the buffering capacity of the soil. Geochemical modeling predicts, and $x$-ray characterization confirms, that precipitation of solids from solution is occurring in the acidic tailings solution/liner interactions studied. X-ray diffraction identified gypsum and alunite group minerals, such as jarosite, as having precipitated after acidic tailings solutions reacted with clay liners. Geochemical modeling predicted that these same phases should be precipitating, along with several amorphous solids not identifiable by $X$-ray diffraction, and illustrates how geochemical modeling can be used, in parallel with mineralogical characterization techniques to delineate the chemical causes for changes in permeability of liner materials. Another mechanism which can contribute to permeability reductions is soil particle dispersion. Some of the effluents from columns leached with the Lucky Mc tailings solutions were found to be dispersive, hence could potentially transport particulate matter containing $230 \mathrm{Th}$ and $226 \mathrm{Ra}$ though no evidence of increased mobility of these radionuclides was observed during the duration of the tests with these solutions. 
The Morton Ranch clay liner and the Morton Ranch overburden exhibited a residual long-term buffering capacity that was able to maintin the column effluent $\mathrm{pH}$ values at a higher level than the influent $\mathrm{pH}$ values. Due to the residual buffering capacity, the $\mathrm{pH}$ of the tailings solution migrating away from the tailings impoundment area $\mathrm{can}$ have a higher $\mathrm{pH}$ than the original tailings solution, even after the initial buffering capacity of the soil has been exhausted. Further work needs to be done to explain the chemical reactions that account for the residual buffering capacity of soils and liners but a likely cause is the redissolution of $\mathrm{Fe}$ and $\mathrm{Al}$ hydrous oxides. Redissolution of $\mathrm{Fe}$ and $\mathrm{Al}$ hydrous oxides consumes hydrogen ions.

To ensure that the initial permeability of the liner is minimized, it is recommended that the liner be compacted to at least $90 \%$ of its maximum compaction as determined by a standard proctor test. A 1 meter thick clay liner, so compacted, with a calcium carbonate content of $4 \%$, or greater, will not only be able to impede the $\mathrm{pH}$ front advance into the surrounding geologic materials for hundreds of years, but will be able, based on empirical evidence, to neutralize the total acidity of a typical tailings pond. As many soils prevalent in the Western U.S. contain carbonate contents significantly $>4 \%$, neutralization of acidic seepage should be easily accomplished naturally or with implacement of appropriate geologic materials.

An initial conclusion drawn from these studies is that the laboratory experiments and geochemical modeling predictions were capable of simulating field observations. The same mineralogical changes and contaminant reductions observed in the laboratory studies were found at a drained evaporation pond (Lucky Mc in Wyoming) with a 4 year history of acid attack. The observed minerals were also predicted, from geochemical (thermodynamic) modeling, to form upon neutralization of the acidic tailings solutions by the contacted sediments. Thus, the laboratory studies, field observations and theoretical model predictions complement each other. Further reports will document the chemistry of mobile species such as $\mathrm{NO}_{3}{ }^{-}$and $\mathrm{SO}_{4}{ }^{2-}$, the radionuclides including ${ }^{230} \mathrm{Th}$ and $226 \mathrm{Ra}$, as well as trace constituents in tailings such as $\mathrm{Mn}, \mathrm{As}$, Se, and V. Geochemical modeling predictions and field data coupled with chemical and hydrological properties will be used to assess the migration potential of the constituents. 


\section{RECOMMENDATIONS FOR FUTURE WORK}

The data presented herein, in concert with data to be published and available data in the literature on the reactions of acidic uranium mill liquors with soils and sediments, have allowed us to identify the controlling chemical mechanisms for several of the major constituents such as calcium, sulfate, and iron. More laboratory work on the cation-exchange contribution to neutralization and trace metal/radionuclide chemistry is needed to confidently predict the $\mathrm{pH}$ front and trace constituent migration rates via linked geochemical and hydrologic transport models.

Indigenous to many sediments and liners is a residual buffering capacity for acidic tailings liquors which is able to maintain column eff luent values above those of the influent acidic solutions even after the initial buffering capacity of the sediment (liner) is exhausted. Further work needs to be done to explain the residual buffering capacity of sediments and liners.

Radium and certain trace elements of consequence in uranium mill tailings, such as Se, As, Mo, $\mathrm{Pb}$ and $\mathrm{V}$ have been monitored in laboratory columns to determine their mobilities. These studies will be documented in a future report. However, field data need to be collected to verify the ability of geochemical modeling predictions and laboratory experiments, to simulate field observations, particularly with regard to radium and trace metal movement.

Information on the solubility and speciation of radium is needed to adequately predict the environmental behavior of radium found in uranium mill tailings. 



\section{CONTENTS}

EXECUTIVE SUMMARY

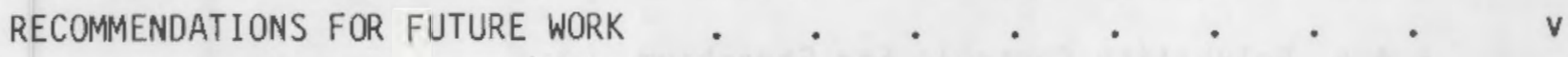

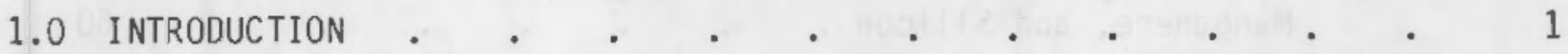

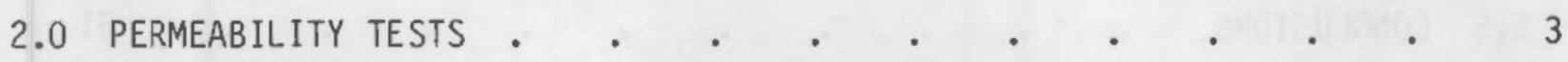

\begin{tabular}{l}
2.1 CHARACTERIZATION OF GEOLOGIC LINER MATERIALS AND \\
TAILINGS SOLUTIONS \\
\hline
\end{tabular}

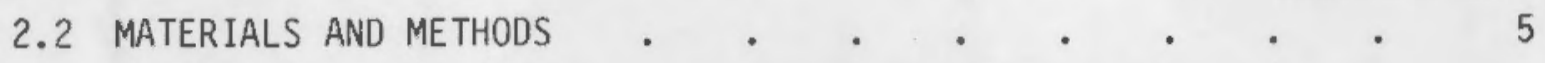

2.3 RESULTS AND DISCUSSION OF THE PERMEABILITY TESTS • • 11

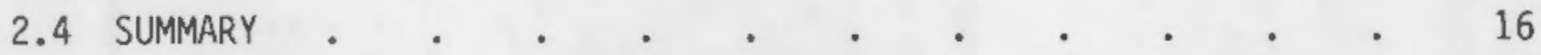

3.0 NEUTRALIZATION BY GEOLOGIC SEDIMENTS . 19

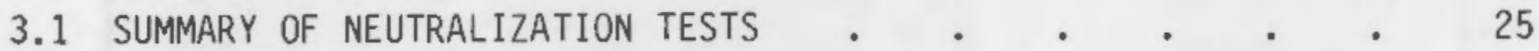

4.0 MINERALOGICAL STABILITY OF LINER MATERIALS . $\quad . \quad$. $\quad$. $\quad 27$

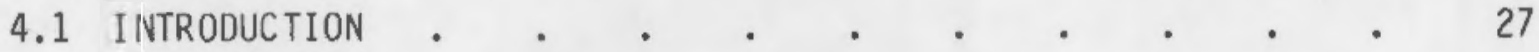

4.2 EXPERIMENTAL METHODS. . . . . . . . . . . . . 27

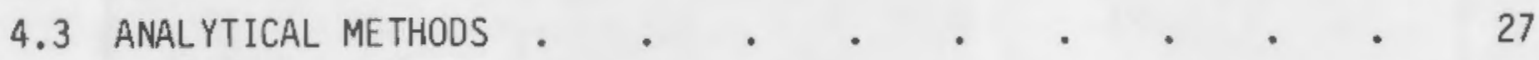

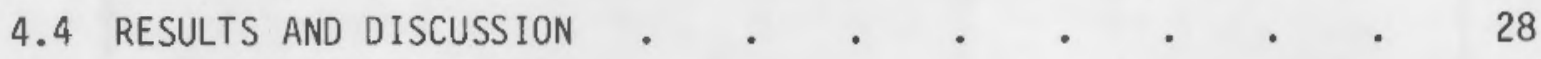

4.4.1 Batch-Type Experiments . . . . . . . . 28

4.4.2 Column-Type Experiments . . . . . . . 34

4.4.3 Lucky Mc Field Study . . . . . . . 34

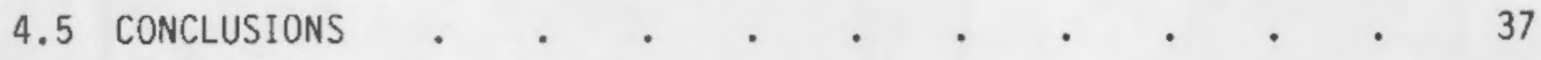

5.0 GEOCHEMICAL MODELING

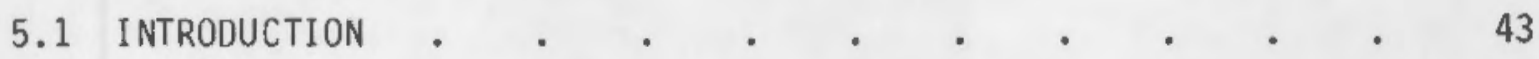

5.2 METHODS . . . . . . . . . . . . . . . . 43

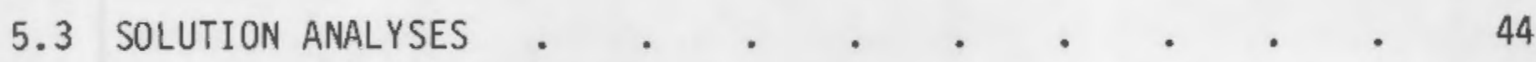

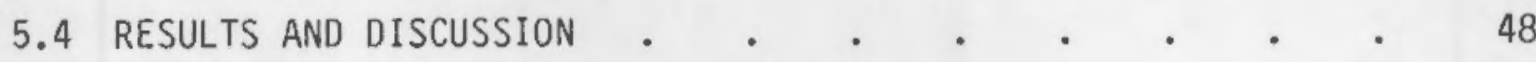


5.4.1 Solubility Controls for Iron. . . . . . . 48

5.4.2 Solubility Controls for Calcium and Sulfate . $\quad 55$

5.4.3 Solubility Controls for Aluminum . $\quad$. 57

5.4.4 Solubility Controls for Strontium, Lead,
Manganese, and Silicon

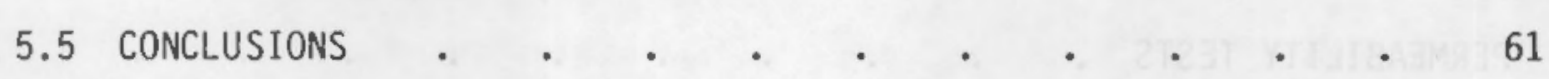

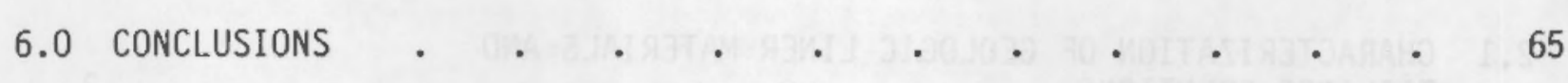

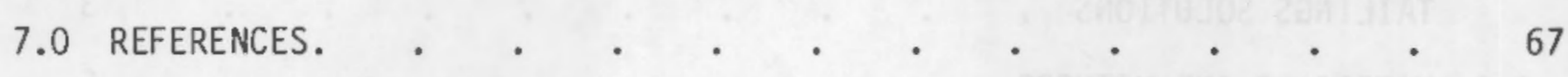




\section{FIGURES}

2.1 Particle Size Summation-Percentage Curve for the Morton

Ranch Clay Liner and Overburden . . . . . . . 5

2.2 Particle Size Summation-Percentage Curve for the Lucky Mc Overburden

2.3 Particle Size Sumation-Percentage Curve for the Dawn Overburden . . . . . . . .

2.4 Pressurized Flow System for Determining Constant Head Permeability.

2.5 Pressurized Permeameter Setup for Measuring Permeability of Clay Liner Materials . . . . . . . 10

2.6 Permeability of Columns 1-3 Versus Pore Volumes of Eff luent

2.7 Permeability of Columns 4-6 Versus Pore Volumes of

2.8 Permeability of the Morton Ranch Overburden Versus Pore Volumes of Eff luent

2.9 Permeability of the Lucky Mc Overburden Soil Versus Pore Volumes of Effluent

2.10 Permeability of the Dawn Overburden Material Versus Pore Volumes of Effluent

3.1 Plot of $\mathrm{pH}$ Versus Pore Volume for Cells 1, 2 and 3 . . . 21

3.2 Plot of pH Versus Pore Volume for Cells 4,5 and 6 . . . 21

3.3 Plot of pH Versus Pore Volume for the Morton Ranch 0verburden Material (cells 7,8 and 9) . . . . . 22

3.4 Plot of $\mathrm{pH}$ Versus Pore Volume for the Lucky Mc Overburden (cel1 10)

3.5 Plot of $\mathrm{pH}$ Versus Pore Volume for the Dawn Overburden Material (cells 11 and 12) . . . . . . . 23

4.1 X-ray Diffraction Traces of Mg-Saturated Clay Fractions . . 30

4.2 X-ray Diffraction Traces of Mg-Saturated, CS-50 Bentonite Clay Fraction 
4.3 X-ray Diffraction Traces of Mg-Saturated, CS-50 Bentonite Clay Fractions

4.4 X-ray Diffraction Traces of Mg-Saturated, Morton Ranch Clay Liner Clay Fractions

4.5 X-ray Diffraction Traces of Air-Dried, Bulk Samples of Morton Ranch Clay Liner

4.6 X-ray Diffraction Traces of Air-Dried, Bulk Samples of Morton Ranch Clay Liner

4.7 X-ray Diffraction Traces of Air-Dried, Bulk Samples of Lucky Mc Overburden

4.8 X-ray Diffraction Traces of Air-Dried, Bulk Samples of Lucky Mc Overburden

4.9 Mineralogical and Soil $\mathrm{pH}$ Profile as a Function of Depth Beneath Evaporation Pond No. 4, Lucky Mc Site, Gas Hills, Wyoming

5.1 Stabilities of Various Fe-Containing Solids Plotted According to the Log of the Activity of $\mathrm{Fe}^{3+}$ Versus $\mathrm{pH}(1 \mathrm{~A})$, and Plot of the Log AP/K Versus $\mathrm{pH}$ for Alunite (1B) . . . . .

5.2 Plot of the $\log A P / K$ Versus Sulfate Concentration for Gypsum (2A) and Celestite (2B)

\section{TABLES}

2.1 Characterization of the Morton Ranch Clay Liner and Overburden Materials from the Morton Ranch, Dawn, and Lucky Mc Mills .

2.2 Characterization of Tailings Solutions From the Exxon Highland Mill, Pathfinder Lucky Mc, and Dawn Midnite Mills, and the Synthetic Tailings Solution in $\mathrm{mg} / \mathrm{l}$. . . 7

2.3 Physical Data for Test Materials • . • • • . •

2.4 Contact Time, Pore Volumes of Effluent and Initial and Final

Permeabilities of the Overburden and Liner Materials Contacted with Original and Synthet ic Tailings Solution

3.1 Analysis of the Eff luent Solution from Morton Ranch Clay Liner (Cell 1) Leached with Synthetic Tailings Solution 
3.2 Analysis of Effluent Solution from Morton Ranch

Clay Liner (Cell 5) Leached with Highland Mill

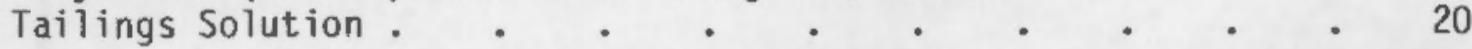

4.1 Mineralogy of Clay Liner Material from Batch Experiments • . 29

5.1 Chemical Analyses of Batch Solutions for Test Liner

Materials and Original Solutions ..$\quad$. $\quad . \quad$. 45

5.2 Chemical Analyses of Effluent Solutions from Permeability

Columns 1 and 5 which Contained the Morton Ranch Clay

Liner Material Reacted with Synthetic and H.M. Tailings

Solut ions, Respectively

5.3 Values of Log AP/K Calculated by WATEQ3 for Batch

Experiments . . . . . . . . . . . 49

5.4 Values of Log AP/K Calculated by MINTEQ for Column

Experiments . . . . . . . . . . . 51 



\subsection{INTRODUCTION}

Below-grade or pit disposal of uranium mill tailings is the "prime option" for long-term management of tailings recommended by the U.S. Nuclear Regulatory Commission (U.S. NRC 1980). To contain the liquid waste in below-grade disposal systems, methods which include liners are recommended in order to reduce, to the "maximum extent reasonably achievable," the seepage of toxic materials into the groundwater. However, the seepage must not result in deterioration of the quality of existing, unaffected ground water. In order to maintain the desired seepage control indefinitely, it is imperative that the liner system maintain its integrity for an extended period of time.

Clay materials have been proposed as liners in tailings impoundments. However, long-term response of clay to contact with tailings solution is not well understood. Crim et al. (1979) found measurable increases in permeability in montmorillonite clays subjected to extended contact with an acidic ( $\mathrm{pH}<1$ ) tailings solution. These changes in permeability varied by more than two orders of magnitude, but tended to increase most dramatically after the $\mathrm{pH}$ of the effluent dropped below 4 (from an initial value near 8 ).

Gee et a1. (1980a,b) studied the effects of extended contact of acidic tailings solution $(\mathrm{pH} \sim 2$ ) on the permeability of native clays from Morton Ranch in central Wyoming. Their results indicated the permeability of the clays gradually decreased with time during a 16 month period. Moreover, the clay material exhibited little physical evidence of deterioration. They attributed the decreases in permeability to the formation of precipitates of iron and aluminum and possibly of secondary clay minerals stable at low pH (<3). Precipitates formed could potentially plug the pores in the clay materials, hence reduce flow. In separate experiments of 3 months duration, no evidence for clay deterioration was detected by $X$-ray diffraction in several clay liner materials reacted with acidic tailings solution. However, Gee et al. (1980a) suggested that more definitive studies were needed to sufficiently evaluate the hydrological, mineralogical, and chemical response of clay liner materials to acidic tailings solutions. Presented in this document are additional and continuing experiments that were conducted to evaluate changes in liner permeability and mineralogy when uranium mill tailings solutions contact clay liner materials.

This report contains four major sections (i.e., Permeablity Tests, Neutralization, Mineralogical Stability of Liner Materials, Geochemical Modeling), each with its own individual summary, and a final section with conclusions. 
.

, 


\subsection{PERMEABILITY TESTS}

Of significant concern in the disposal of uranium mill tailings is that the low $\mathrm{pH}$, high sulfate, high ionic strength tailings solutions could react with clay liners or the surrounding geologic media and, in time, cause liner failure (i.e., result in an increase in permeability of the given material). This concern has prompted an investigation into the time dependence of permeability changes that $c$ an occur when uranium mill tailings solutions interact with clay liners and soil materials. Permeability tests were run in flowthrough columns where various real and synthetic tailings solutions were reacted with clay liners and other geologic materials. The materials used were a clay liner and an overburden material from the Morton Ranch mill site (a proposed uranium mill) in Wyoming, and overburden materials from the Dawn MidniteMine mill in Washington, and the Pathfinder Gas-Hills (Lucky Mc) mill in Wyoming. Detailed descriptions of the geology of the Morton Ranch site and the Dawn and Lucky Mc mills are given in the Environmental Impact Reports for these mills (U.S.NRC 1977, U.S.NRC 1979, and Washington State 1980).

\subsection{CHARACTERIZATION OF GEOLOGIC MATERIALS AND TAILINGS SOLUTIONS}

All geologic characterization work on these materials was done using standard procedures (Black $1965 \mathrm{a}, \mathrm{b})$. Table 2.1 lists the key physical and chemical characteristics of the test materials. There was considerable variation in the geologic materials tested. The Morton Ranch clay liner material analyzed was a composite of sandstone, siltstone, mudstone and shale. The textural classification of the Morton Ranch clay liner is a silty clay loam. The saturated paste of this soil is alkaline and the organic matter content and the CEC are higher than that of any of the other geologic materials studied. The Morton Ranch overburden material is a sandy loam. It differs from the Morton Ranch clay liner by having a higher proportion of sand, an alkaline $\mathrm{pH}$ of 8.5, a higher but still low calcium carbonate content of $0.19 \%$ and a lower organic matter content. The Pathfinder Lucky Mc overburden (ForellePatent Association) is a silty clay. A distinctive feature of the Lucky Mc overburden in the relatively high calcium carbonate content of $3.98 \%$, in contrast to the low calcium carbonate content exhibited by the other test materials. The Dawn overburden is classified by texture as a sandy loam. It has a neutral $\mathrm{pH}$, a moderate $\mathrm{Eh}$, and a low cation exchange capacity (CEC). The difference in the particle size distribution between the Morton Ranch clay liner and overburden is shown in Figure 2.1. The particle size distributions for the Lucky Mc and Dawn overburdens are shown in Figures 2.2 and 2.3, respectively.

Characterization of the tailings solutions from the three sites is shown, along with the components of the prepared synthetic tailings solutions, in Table 2.2. Inductively Coupled Plasma emission spectroscopy (ICP) was used for macro-cation analysis while graphite furnace atomic absorption (AA) was used to analyze trace metals. Anions were determined by ion chromatography and titration and radionuclides by $X$-ray and $\gamma$-ray radioanalytical techniques. 
TABLE 2.1. Characterization of the Morton Ranch Clay Liner and Overburden Materials from the Morton Ranch Site, the Dawn, and Lucky Mc Mills

\begin{tabular}{|c|c|c|c|c|}
\hline & $\begin{array}{c}\text { Morton } \\
\text { Ranch } \\
\text { Clay Liner } \\
\end{array}$ & $\begin{array}{c}\text { Morton } \\
\text { Ranch } \\
\text { Overburden } \\
\end{array}$ & $\begin{array}{l}\text { Lucky Mc } \\
\text { Overburden } \\
\end{array}$ & $\begin{array}{c}\text { Dawn } \\
\text { Overburden } \\
\text { (glacial } \\
\text { cobble) } \\
\end{array}$ \\
\hline $\begin{array}{l}\text { Water Content }(\mathrm{g} / \mathrm{g})(\%) \\
\quad \text { (after air drying) }\end{array}$ & 4.10 & 1.15 & 2.95 & 1.12 \\
\hline Particle Density $\left(\mathrm{g} / \mathrm{cm}^{3}\right)$ & 2.72 & 2.68 & 2.89 & 2.71 \\
\hline $\begin{array}{l}\text { Particle Size } \\
\text { Distribution }(w t \%) \\
\text { Sand }(50-2000 \mu \mathrm{m}) \\
\text { Silt }(2-50 \mu \mathrm{m}) \\
\text { Clay }(<2 \mu \mathrm{m})\end{array}$ & $\begin{array}{l}12.0 \\
54.0 \\
34.0\end{array}$ & $\begin{array}{r}76 \\
15 \\
9\end{array}$ & $\begin{array}{r}7 \\
45 \\
48\end{array}$ & $\begin{array}{l}64 \\
29.5 \\
6.5\end{array}$ \\
\hline $\mathrm{pH}$ of Saturated Paste & 8.2 & 8.5 & 8.0 & 7.0 \\
\hline $\begin{array}{l}\text { Eh of Saturated Paste } \\
\text { (volts) }\end{array}$ & +0.406 & +0.345 & +0.336 & +0.349 \\
\hline $\begin{array}{l}\text { EC of Saturated Extract } \\
(m \operatorname{mhos} / \mathrm{cm})\end{array}$ & 0.70 & 0.19 & 6.5 & 0.31 \\
\hline Organic Matter $(g / g)(\%)$ & 1.44 & 0.19 & 0.71 & 0.95 \\
\hline $\mathrm{CaCO}_{3}(g / g)(\%)$ & 0.04 & 0.19 & 3.98 & 0.06 \\
\hline $\begin{array}{l}\text { Cation Exchange Capacity } \\
\text { (CEC) (meq/100g) }\end{array}$ & 31.6 & 7.8 & 19.4 & 7.7 \\
\hline $\begin{array}{l}\text { Water Soluble Cations } \\
\text { (meq/100g) (1:1 Extract) } \\
\mathrm{K} \\
\mathrm{Na} \\
\mathrm{Ca} \\
\mathrm{Mg}\end{array}$ & $\begin{array}{l}\text { ND } \\
\text { ND } \\
\text { ND } \\
\text { ND }\end{array}$ & $\begin{array}{l}0.22 \\
1.10 \\
2.72 \\
1.11\end{array}$ & $\begin{array}{r}1.25(a) \\
34.24(a) \\
21.23(a) \\
18.18(a)\end{array}$ & $\begin{array}{l}0.22 \\
0.59 \\
4.95 \\
2.51\end{array}$ \\
\hline
\end{tabular}

(a) Done on a 2:1 saturated extract ND $=$ Not determined

A future report will discuss observed spectral and matrix interferences encountered in analyzing the low pH, high ionic strength, high sulfate tailings solutions and will describe more fully the analytical techniques that were used to overcome these interferences. 


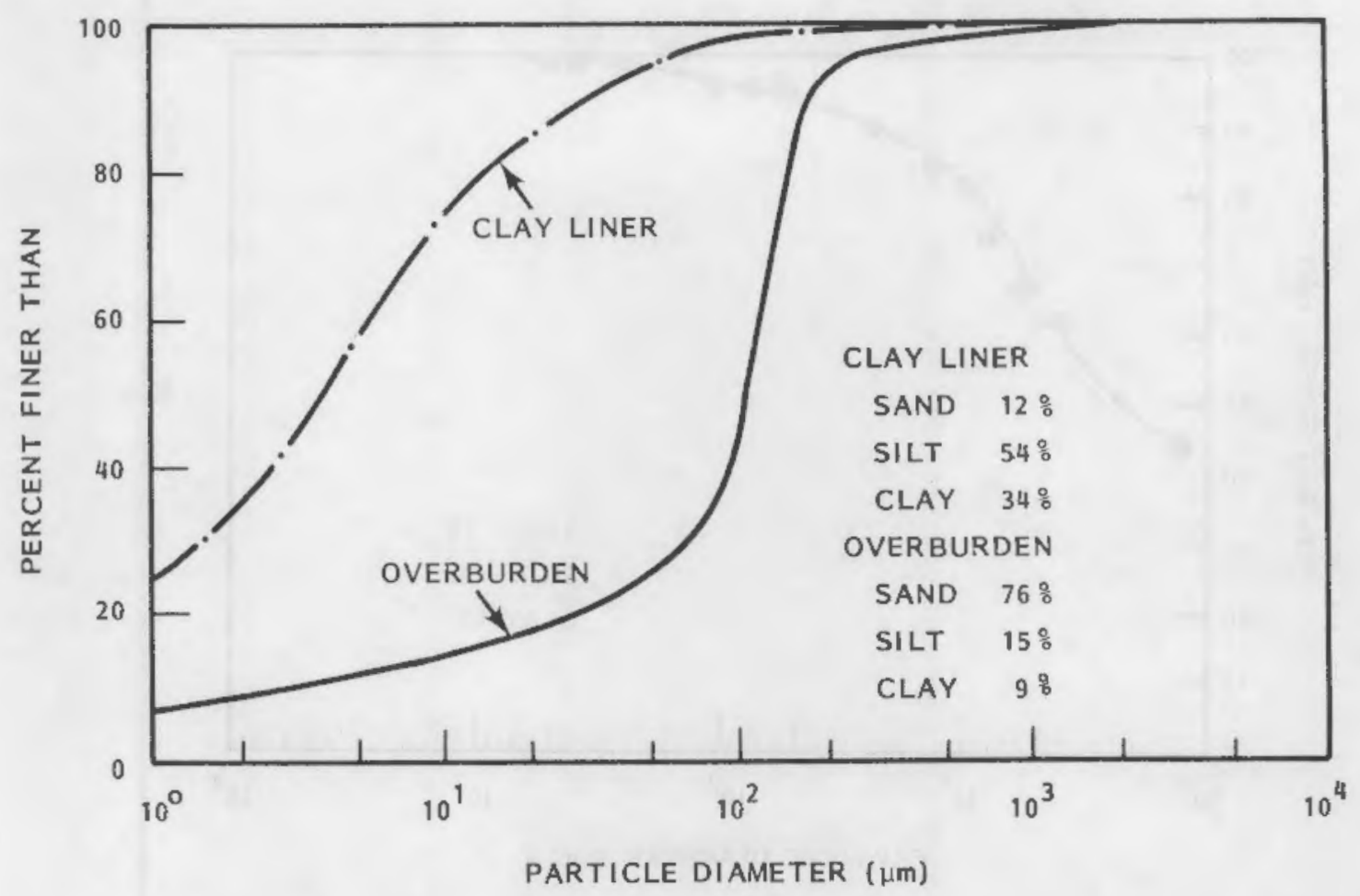

FIGURE 2.1. Particle Size Summation-Percentage Curve for the Morton Ranch Clay Liner and Overburden

\subsection{MATERIALS AND METHODS}

The liner and overburden materials used in the tests were compacted into cylindrical cells having characteristics as stated below in Table 2.3. The method used for compaction was the sliding-weight tamper method (ASTM 1978).

All of the cells, with the exception of Cell 1, were initially saturated with ground water. Cell 1 was contacted only with synthetic tailings solution. Constant head permeability tests were then run on all cells. Cells 1, 2, and 3 were leached with synthetic tailings solution while the remaining cells were leached with the tailings solutions indicated by Table 2.3. The synthetic tailings solution contains the major constituents of the tailings solution, but is free of radioactivity (Table 2.2).

The method used for determining permeability was the ASTM Method for determining constant head permeability (ASTM 1978), with minor modifications as described by Gee et al. (1980a). The flow through the cells was from bottom to the top to ensure saturated flow conditions. A schematic of the pressurized permeameter system is shown in Figure 2.4. 


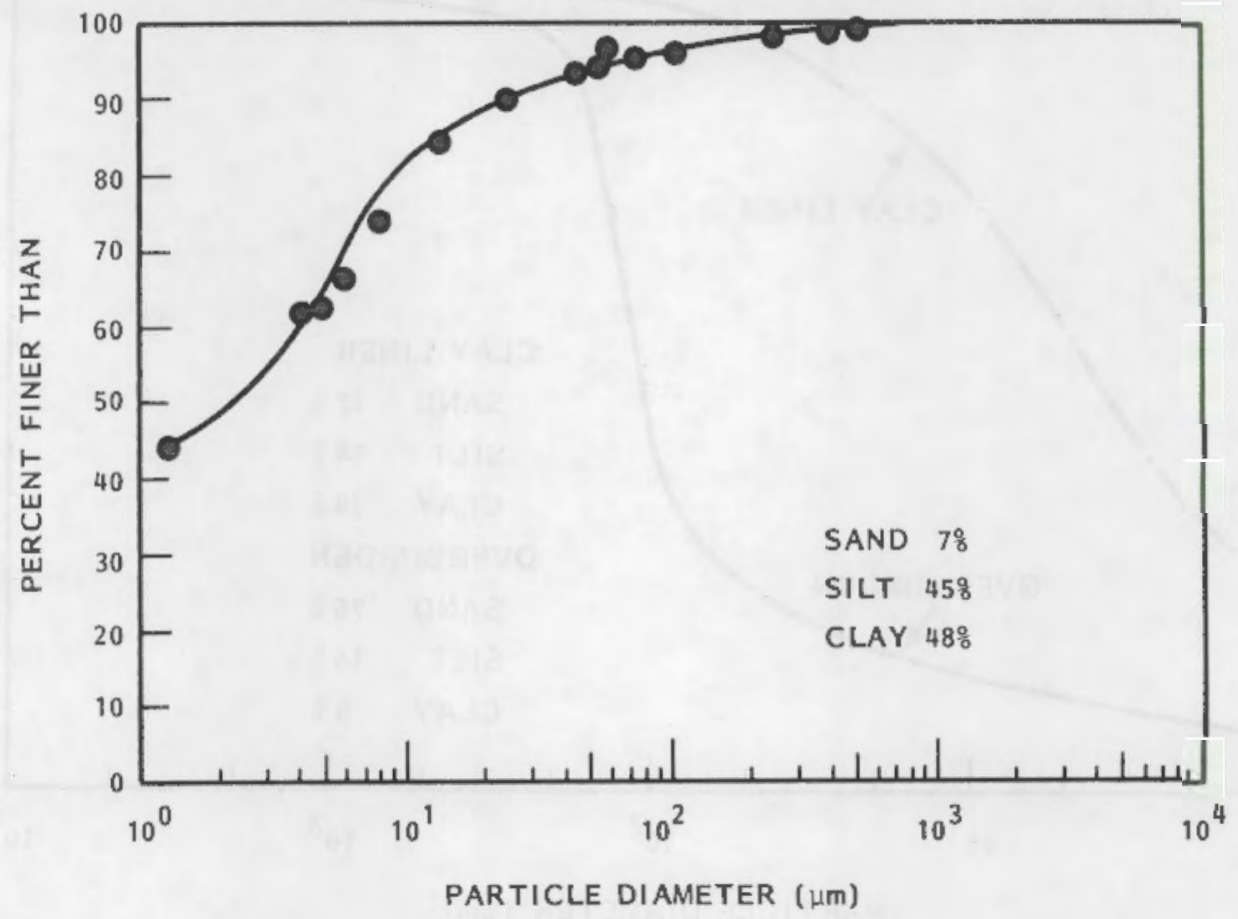

FIGURE 2.2. Particle Size Summation-Percentage Curve for the Lucky Mc Overburden

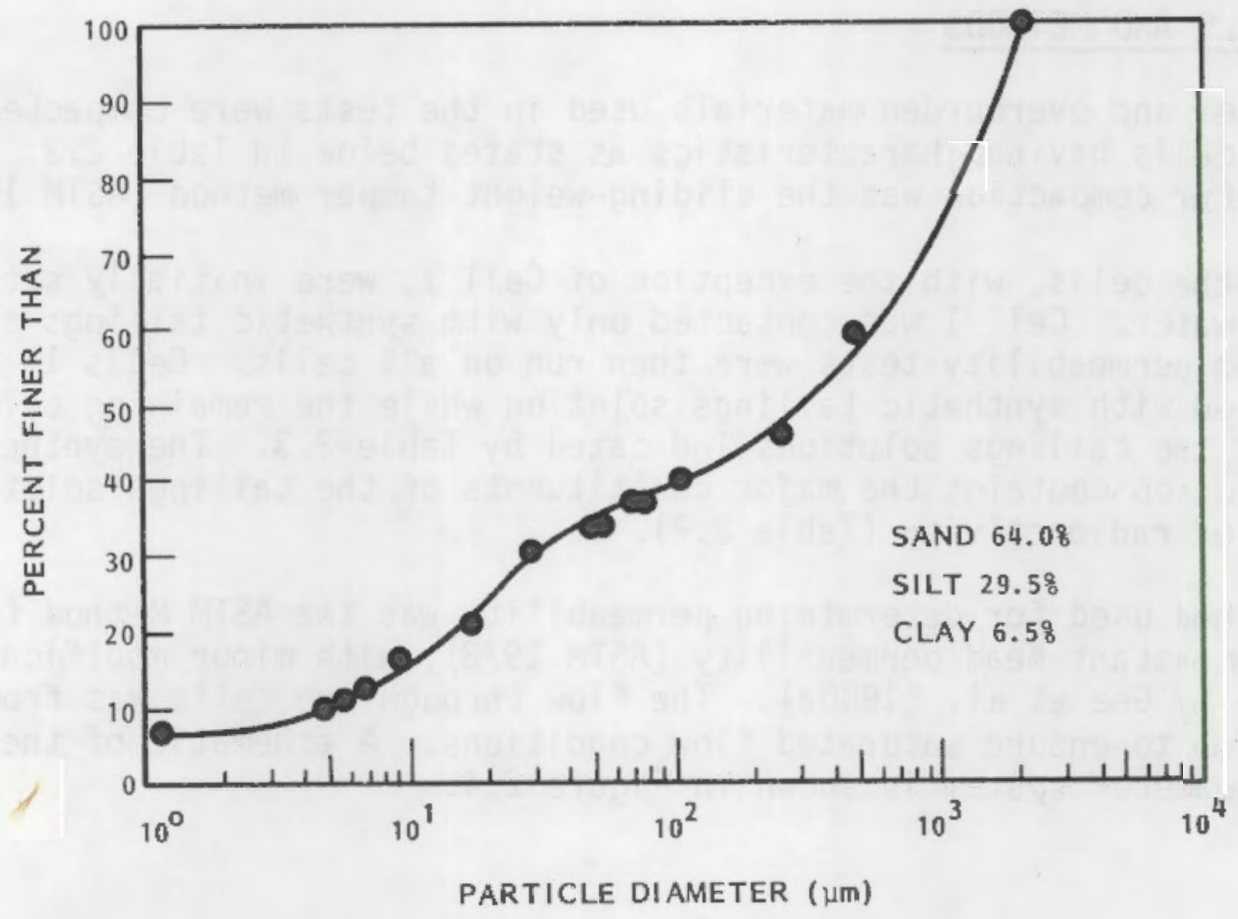

FIGURE 2.3. Particle Size Summation-Percentage Curve for the Dawn Overburden 
TABLE 2.2. Characterization of Tailings Solutions From the Exxon Highl and Mill,Lucky Mc, and Dawn Mills, and the Synthetic Tailings Solution in $\mathrm{mg} / \mathrm{l}$ (unless otherwise noted)

\begin{tabular}{|c|c|c|c|c|}
\hline Parameter & $\begin{array}{l}\text { Highland Mill } \\
\text { Tailings } \\
\text { Solution } \\
\end{array}$ & $\begin{array}{l}\text { Pathfinder } \\
\text { Lucky Mc } \\
\text { Tailings } \\
\text { Solution } \\
\end{array}$ & $\begin{array}{l}\text { Dawn Tailings } \\
\text { Solution } \\
\end{array}$ & $\begin{array}{l}\text { Synthet ic } \\
\text { Tailings } \\
\text { Solution } \\
\end{array}$ \\
\hline $\mathrm{Ag}$ & $<0.05$ & $<0.05$ & & \\
\hline Al & 600 & 1,030 & 867 & 595 \\
\hline As & 3.50 & 19.3 & 1.86 & \\
\hline B & 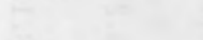 & 1.2 & & \\
\hline $\mathrm{Ba}$ & $<0.05$ & 0.092 & & \\
\hline $\mathrm{Ca}$ & 537 & 600 & 545 & 540 \\
\hline $\mathrm{Cd}$ & 0.1 & 0.28 & & \\
\hline $\mathrm{Cr}$ & 2.7 & 2.36 & & \\
\hline $\mathrm{Cu}$ & 2.3 & 1.51 & 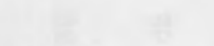 & \\
\hline $\mathrm{Fe}$ & 2,215 & 2,780 & 2,626 & 2,217 \\
\hline k & $39.5^{(b)}$ & 156 & 75.6 & \\
\hline Li & 0.9 & & & \\
\hline $\mathrm{Mg}$ & 688 & 1,220 & 474 & 650 \\
\hline Mn & 63.5 & 163 & 740 & \\
\hline Mo & 0.35 & 8.413 & 0.28 & \\
\hline $\mathrm{Na}$ & 343 & 1,630 & 46 & 350 \\
\hline $\mathrm{Ni}$ & 3.0 & & & \\
\hline $\mathbf{P}$ & 30 & & & \\
\hline $\mathrm{Pb}$ & $<1.0$ & 0.87 & & \\
\hline Se & 0.6 & 1.61 & 0.02 & 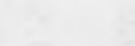 \\
\hline Si & 233.5 & 283 & 160 & \\
\hline $\mathrm{Sr}$ & 15.7 & 14.0 & & \\
\hline Th & $<1$ & & & \\
\hline U & $100(39.7)^{(a)}$ & & & \\
\hline $2 n$ & 8.4 & 16.9 & & \\
\hline $\mathrm{Cl}$ & 97.1 & 1,090 & 28 & 103 \\
\hline $\mathrm{NO}_{3}$ & 16.5 & 302.0 & 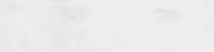 & 15 \\
\hline $\mathrm{SO}_{4}$ & 12,850 & 26,400 & 18,200 & 13,000 \\
\hline $\mathrm{EC}($ mmhos $/ \mathrm{cm})$ & 18.2 & 42.0 & 16.0 & 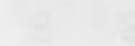 \\
\hline$F$ & 4 & 28 & 30 & \\
\hline $\mathrm{PO}_{4}$ & & & 31 & \\
\hline $\mathrm{pH}$ & 1.8 & 1.2 & 1.8 & 2.0 \\
\hline Eh & 910 & 698 & 842 & \\
\hline $210 \mathrm{~Pb}$ & $9,701 \mathrm{pCi} / \mathrm{l}$ & $16,000 \mathrm{pCi} / 1$ & $1610 \mathrm{pCi} / 1$ & \\
\hline${ }^{230}$ Th & $227,286 \mathrm{pCi} / 1$ & $167,000 \mathrm{pCi} / 1$ & $86,007 \mathrm{pCi} / 1$ & \\
\hline $238 \mathrm{U}$ & $13,216 \mathrm{pCi} / 1$ & $16,800 \mathrm{pCi} / 1$ & $13,758 \mathrm{pCi} / 1$ & \\
\hline $235 \mathrm{U}$ & $620 \mathrm{pCi} / 1$ & $789 \mathrm{pCi} / 1$ & $429 \mathrm{pCi} / 1$ & \\
\hline${ }^{226} \mathrm{Ra}$ & $2,252 \mathrm{pCi} / 1$ & $4,900 \mathrm{pCi} / \mathrm{I}$ & $3,355 \mathrm{pCi} / 1$ & \\
\hline Totals & $253,075 \mathrm{pCi} / 1$ & $205,489 \mathrm{pCi} / 1$ & $105,159 \mathrm{pCi} / 1$ & \\
\hline
\end{tabular}

(a) Radiochemical analysis

(b) $\mathrm{A} \mathrm{K}^{+}$value of 0.5 was used in the geochemical modeling portion of the study as the other value was not available at that time 
TABLE 2.3. Physical Data for Test Materials

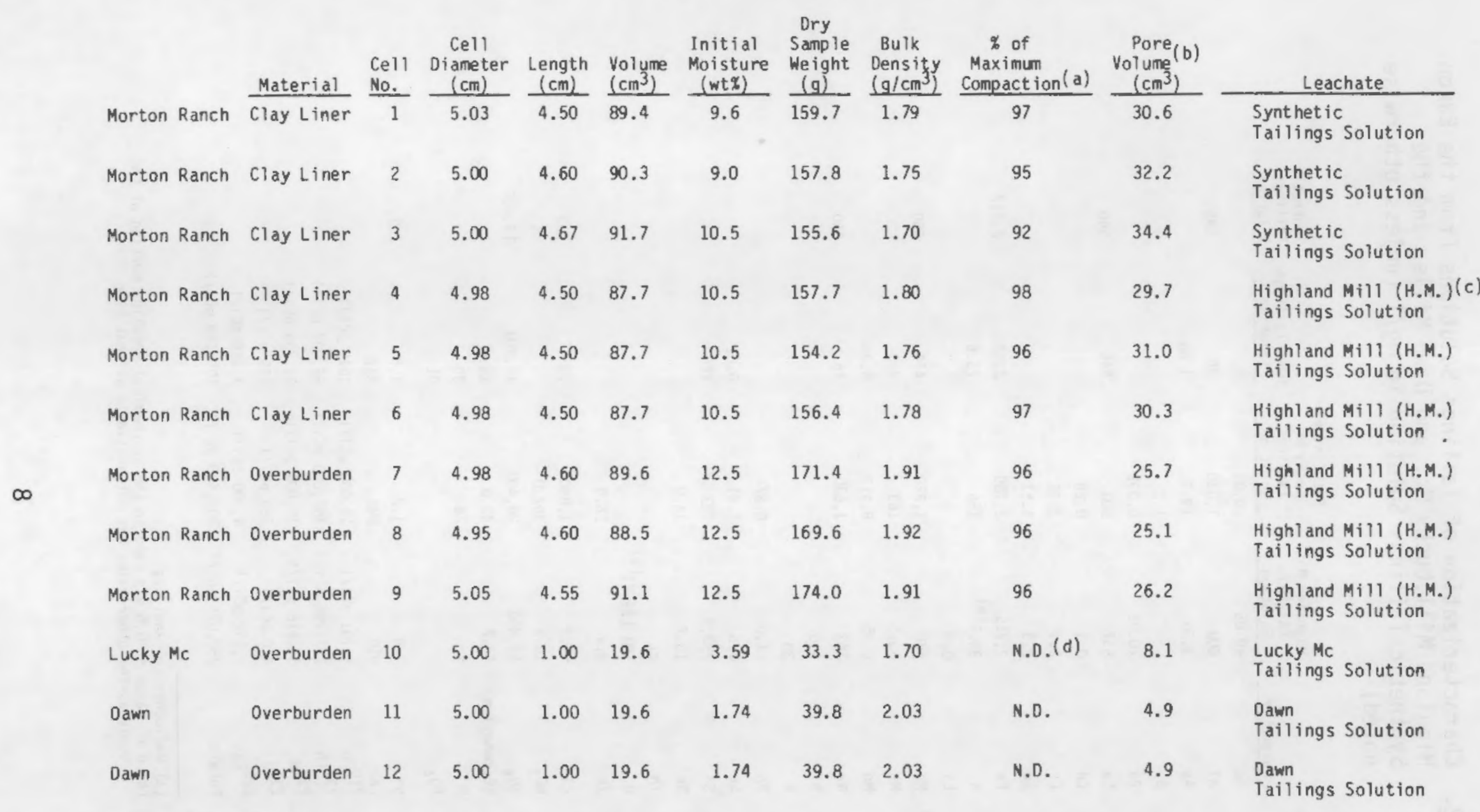

(a) Maximum compaction was detemined for the Morton Ranch overburden and clay liner by a standard procter test (Black 1965 ).

(b) Pore Volume $=$ volume of void $\mathrm{space}$ in total sample volume $\left(\mathrm{cm}^{3}\right)$.

(c) H.M. = Highl and Mill.

(d) N.D. = Not Determined 


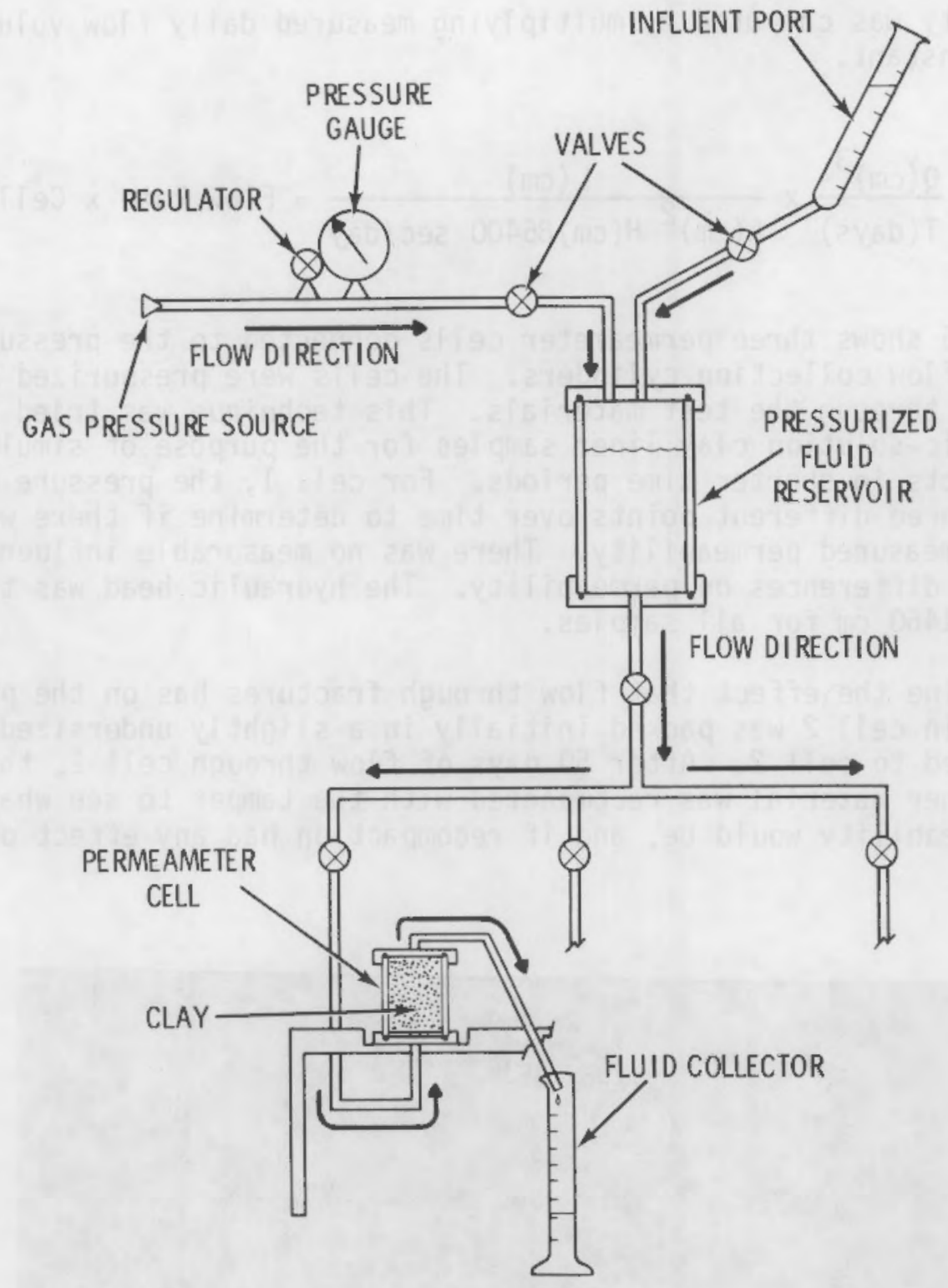

FIGURE 2.4. Pressurized Flow System for Determining Constant Head Permeability

The permeability $(K)$ is calculated by multiplying the flow rate in $\mathrm{ml} /$ day by a cell constant. The cell constant is the length of the cell (L) divided by the cross-sectional area (A) times the hydraulic head (H).

$$
\text { Cel1 Constant }=\frac{L(\mathrm{~cm})}{A(\mathrm{~cm})^{2} H(\mathrm{~cm})} \times \frac{1}{\mathrm{sec} / \text { day }} \frac{1}{86400}
$$


The permeability was computed by multiplying measured daily flow volumes $(Q / T)$ by the cell constant.

$$
K(\mathrm{~cm} / \mathrm{s})=\frac{Q(\mathrm{~cm})^{3}}{T(\text { days })} \times \frac{\mathrm{L}(\mathrm{cm})}{\mathrm{A}(\mathrm{cm})^{2} \mathrm{H}(\mathrm{cm}) 86400 \mathrm{sec} / \text { day }}=\text { Flow Rate } \times \text { Cell Constant }
$$

Figure 2.5 shows three permeameter cells connected to the pressure system and to the outflow collection cylinders. The cells were pressurized to accelerate the flow through the test materials. This technique was tried initially on the synthetic-solution clay liner samples for the purpose of simulating long-term effects in shorter time periods. For cell 1, the pressure was increased at three different points over time to determine if there was any effect on the measured permeability. There was no measurable influence of hydraulic head differences on permeability. The hydraulic head was thereafter maintained at $1460 \mathrm{~cm}$ for all samples.

To determine the effect that flow through fractures has on the permeability, material in cell 2 was packed initially in a slightly undersized cell and then transferred to cell 2. After 50 days of flow through cell 2, the surface of the clay liner material was recompacted with the tamper to see what the change in permeability would be, and if recompaction had any effect on chemical migration.

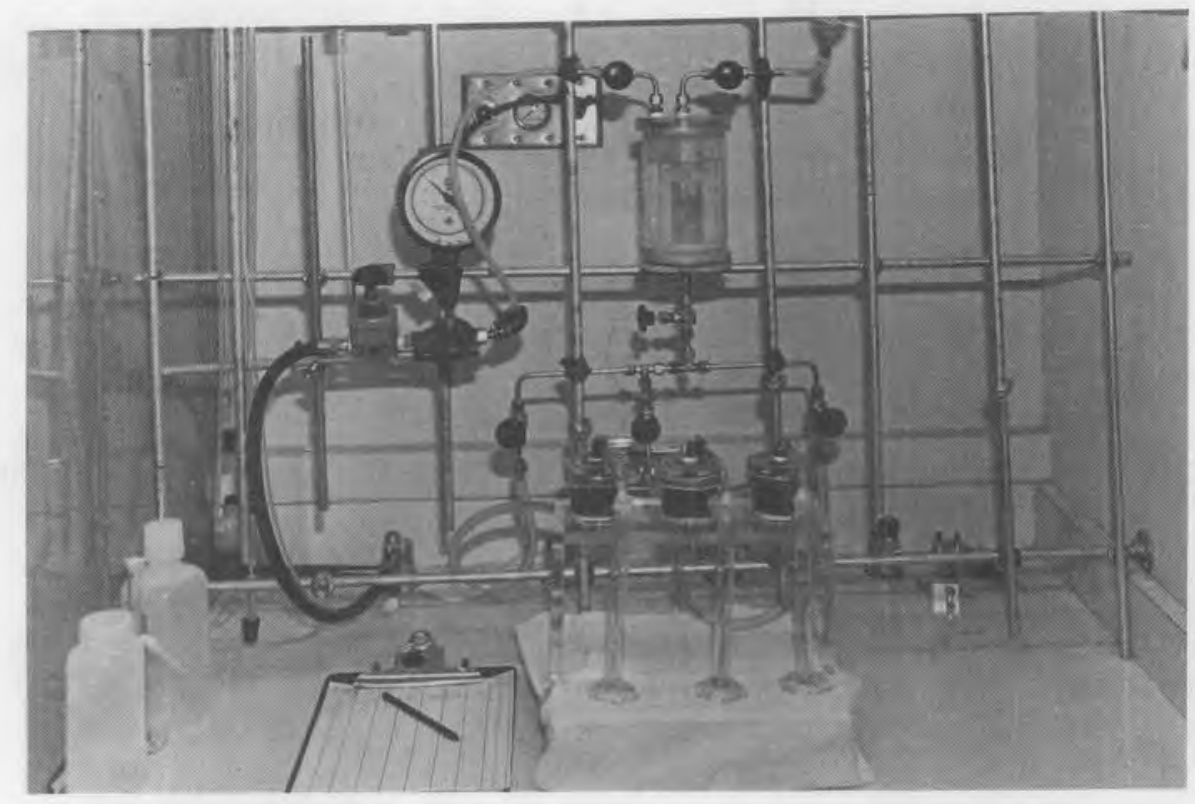

FIGURE 2.5. Pressurized Permeameter Setup for Measuring Permeability of Clay Liner Materials 


\subsection{RESULTS AND DISCUSSION OF THE PERMEABILITY TESTS}

Table 2.4 gives the time of contact between the solutions and the respective clay liners and overburden materials along with the number of pore volumes of solution that passed through the cell during the given time period. The beginning permeability was usually determined by averaging several data points taken over the initial 3 to 10 days of contact time, depending upon flow. The approximate number of pore volumes to which this corresponds can be found in Table 2.4. The final permeability achieved in the columns is also presented.

The changes in permeability for the Morton Ranch clay liner material contacted with synthetic tailings solution are shown in Figure 2.6.

Cells 1 and 3 experienced a gradual, continuous decrease in permeability. For cell 2 (which was recompacted in place after 50 days of solution contact), the permeability dropped by an order of magnitude after recompaction. One can conclude, from the data, that physical manipulation (compaction) has a dramatic effect on permeability, and that physical mechanisms which optimize density and compaction and minimize channel cracks and fracture flow will likely play an important role in determining the ultimate permeability of the liner. The nonrecompacted cells (cells 1 and 3 ) experienced a decrease in permeability of approximately one-half order of magnitude over the 1000 day period.

The effect of the Highland Mill tailings solution on the permeability of the Morton Ranch clay liner is shown in Figure 2.7.

The permeability of columns 5 and 6 continuously decreased as long as the tailings solution was passing through the columns. Flow through column 4 ceased after nearly $1 \mathrm{yr}$ ( 350 days) of testing. During this time <1 pore volume of effluent was collected. The initial permeability of this column was very low $\left(3.5 \times 10^{-10} \mathrm{~cm} / \mathrm{s}\right)$. The permeabilities of columns 5 and 6 decreased anywhere from 1 order of magnitude for column 6 to over 2 orders of magnitude for column 5. The more dramatic decrease in permeability of the Morton Ranch clay liner reacted with Highland Mill tailings solution, compared to the decrease in permeability observed when the same liner was reacted with synthetic tailings solutions, could be due to the formation of additional precipitates in the Highland Mill tailings solutions/clay liner interactions. The precipitation of additional solid phases could be caused by the presence of elements in the real tailings solutions that are not encountered in the synthetic tailings solutions. These are elements that are constituents of the additional solids and whose presence is necessary for the solid to precipitate. An example of such an element is $\mathrm{K}^{+}$, which is necessary for the precipitation of $\mathrm{K}$-jarosite $\left[\mathrm{KFe}_{3}\left(\mathrm{SO}_{4}\right)_{2}(\mathrm{OH})_{6}\right]$ and alunite $\left.\left[\mathrm{KAl}_{3} \mathrm{SO}_{4}\right)_{2}(\mathrm{OH})_{6}\right]$. Potassium is found in the Highland Mill tailings solution but not in the synthetic tailings solution. Both K-jarosite and alunite were identified, by X-ray diffraction, in Highland Mill tailings solutions/clay liner interactions but not after the synthetic tailings solution reacted with the clay liner (Morton Ranch clay liner). The permeabilities observed in the Morton Ranch clay liner material (columns 1 through 6 ) are lower than the liner permeability $\left(10^{-7} \mathrm{~cm} / \mathrm{s}\right.$ ) recommended by the Environmental Protection Agency (U.S. EPA 1978). The columns 
TABLE 2.4. Contact Time, Pore Volumes of Eff luent and Initial and Final Permeabilities of the Overburden and Liner Materials Contacted with Original and Synthetic Tailings Solution

\begin{tabular}{|c|c|c|c|c|}
\hline Cell & $\begin{array}{c}\text { Contact Time } \\
\text { Days } \\
\end{array}$ & $\begin{array}{c}\text { Pore } \\
\text { Volumes } \\
\end{array}$ & $\begin{array}{c}\text { Beginning } \\
\text { Permeability }(\mathrm{cm} / \mathrm{s})\end{array}$ & $\begin{array}{c}\text { Final } \\
\text { Permeability }(\mathrm{cm} / \mathrm{s}) \\
\end{array}$ \\
\hline 1 & 1024 & 34.67 & $7.0 \times 10^{-9}$ & $1.4 \times 10^{-9}$ \\
\hline 2 & 947 & 21.36 & $2.8 \times 10^{-8}$ & $7.5 \times 10^{-10}$ \\
\hline 3 & 929 & 13.77 & $2.2 \times 10^{-9}$ & $8.0 \times 10^{-10}$ \\
\hline 4 & 350 & 0.89 & $3.5 \times 10^{-10}$ & f low ceased \\
\hline 5 & 838 & 18.66 & $5.0 \times 10^{-8}$ & $8.1 \times 10^{-11}$ \\
\hline 6 & 836 & 9.41 & $2.5 \times 10^{-9}$ & $2.5 \times 10^{-10}$ \\
\hline 7 & 102 & 44.17 & $9.2 \times 10^{-8}$ & $3.2 \times 10^{-7}$ \\
\hline 8 & 95 & 70.65 & $1.0 \times 10^{-7}$ & $4.9 \times 10^{-7}$ \\
\hline 9 & 95 & 93.75 & $1.0 \times 10^{-6}$ & $8.5 \times 10^{-6}$ \\
\hline 10 & 117 & 34.18 & $4.4 \times 10^{-8}$ & $2.4 \times 10^{-8}$ \\
\hline 11 & 56 & 108.02 & $2.8 \times 10^{-7}$ & $1.7 \times 10^{-7}$ \\
\hline 12 & 59 & 57.80 & $3.8 \times 10^{-7}$ & $6.8 \times 10^{-8}$ \\
\hline
\end{tabular}

packed with the Morton Ranch clay liner that had been contacted with Highland Mill tailings solutions (columns 4 through 6 ) all had final permeabilities less than $10^{-9} \mathrm{~cm} / \mathrm{s}$.

The final permeabilities of the Morton Ranch overburden were greater than initial values for all 3 test samples (Figure 2.8). This overburden had the highest sand content ( $76 \%$ by weight) and the lowest amount of fine material (less than $25 \%$ passing a $53 \mu \mathrm{m}$ screen). The average final permeability of the three cells was $3.1 \times 10^{-6}$. The $\mathrm{pH}$ of the eff luent solution dropped to near 2 before any appreciable change in permeability was observed. The low pH coupled with relatively high flow rates could be responsible for the migration of fine particles through the pores of the sand resulting in the increased permeability.

The Lucky Mc Overburden soil leached with the Lucky Mc tailings solution had a final permeability of around $2.4 \times 10^{-8} \mathrm{~cm} / \mathrm{s}$ which was a slight decrease from the permeability encountered at the beginning of the experiment (Figure 2.9).

Cells 11 and 12 , which contained overburden materials from the Dawn Midnite Mine site leached with the Dawn tailings solutions, showed slight declines in permeabilities during the time the cells were in operation (Figure 2.10). 


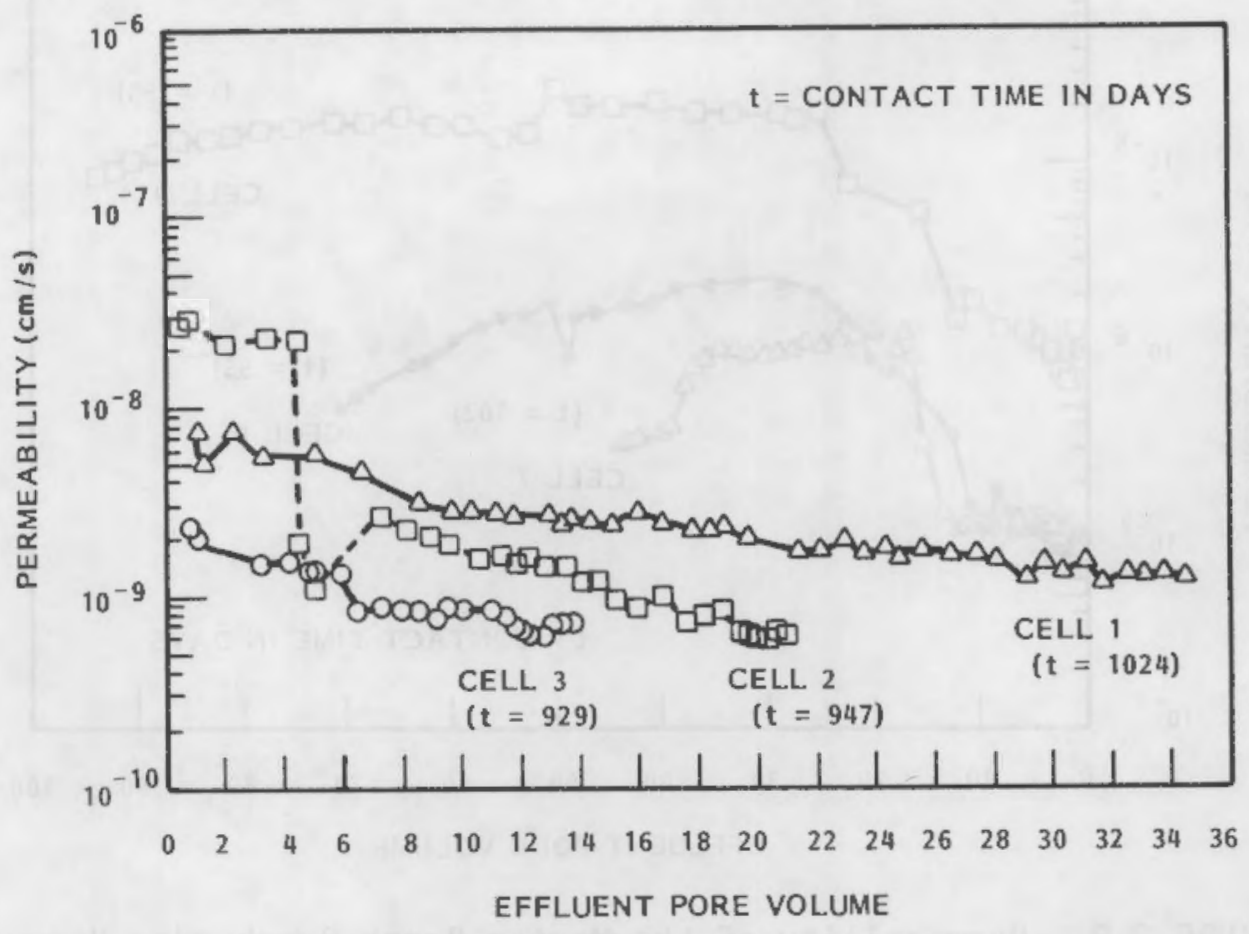

FIGURE 2.6. Permeability of Columns 1-3 Versus Pore Volumes of Eff luent

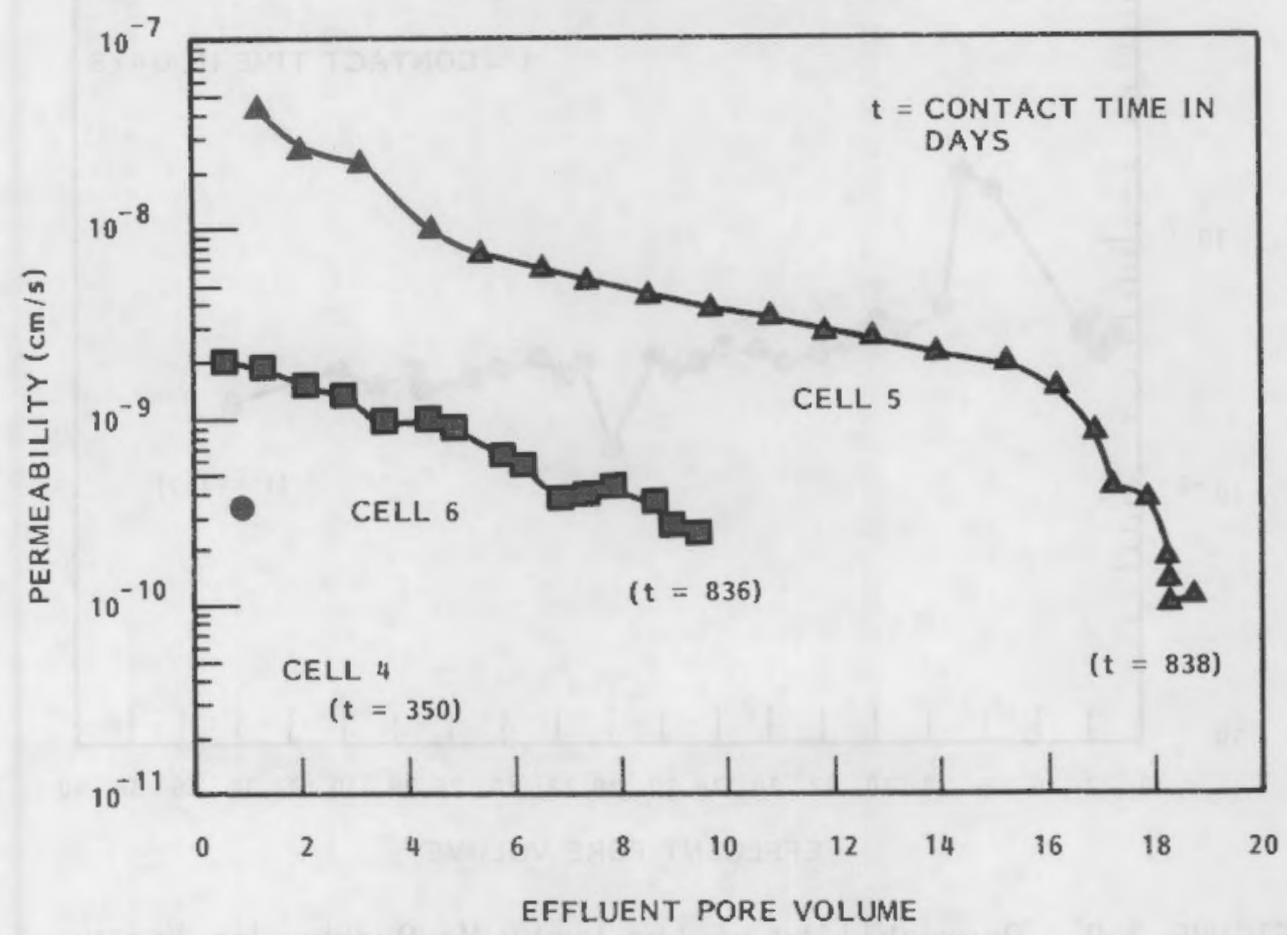

FIGURE 2.7. Permeability of Columns 4-6 Versus Pore Volumes of Effluent 


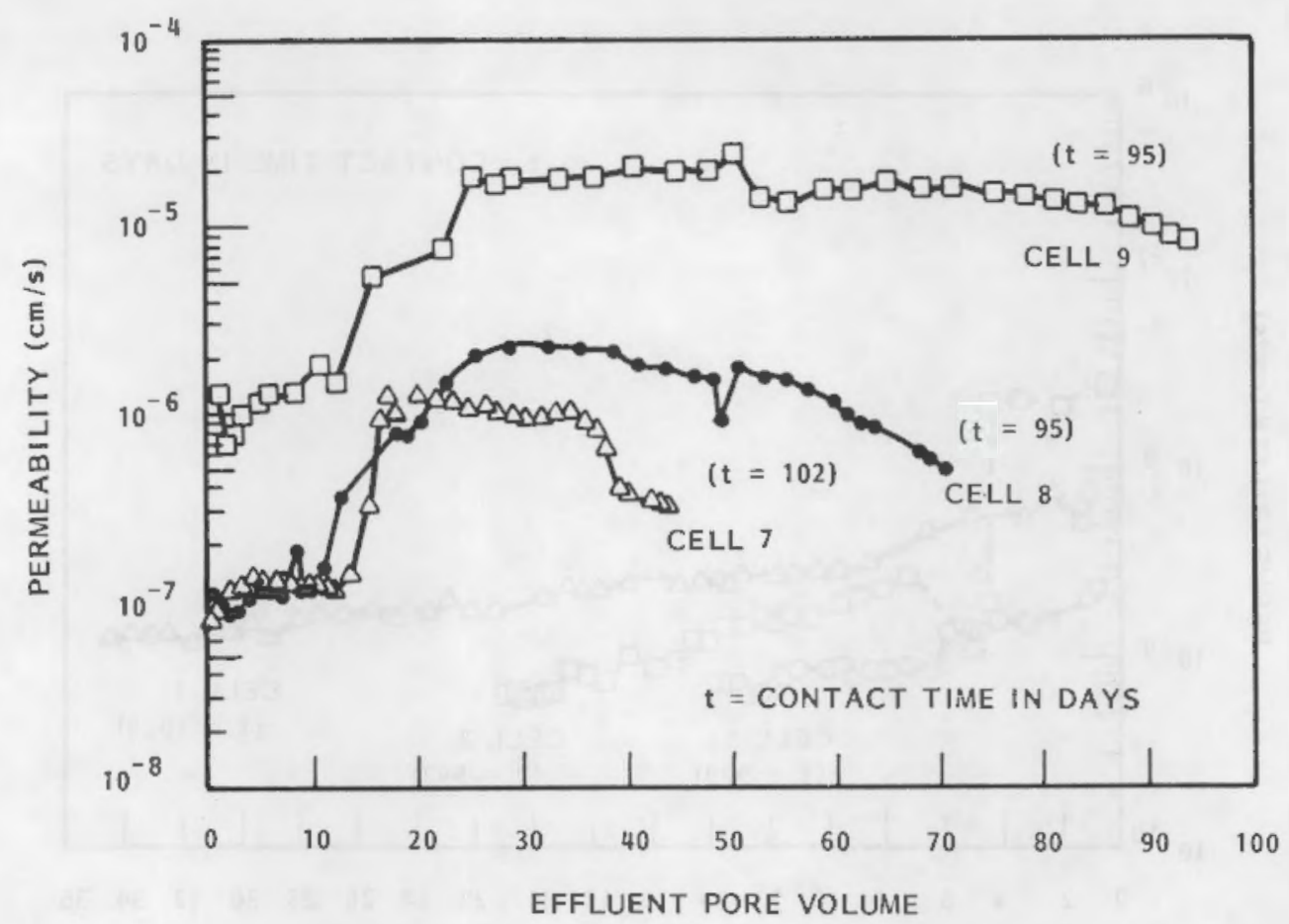

FIGURE 2.8. Permeability of the Morton Ranch Overburden Versus Pore Volumes of Effluent

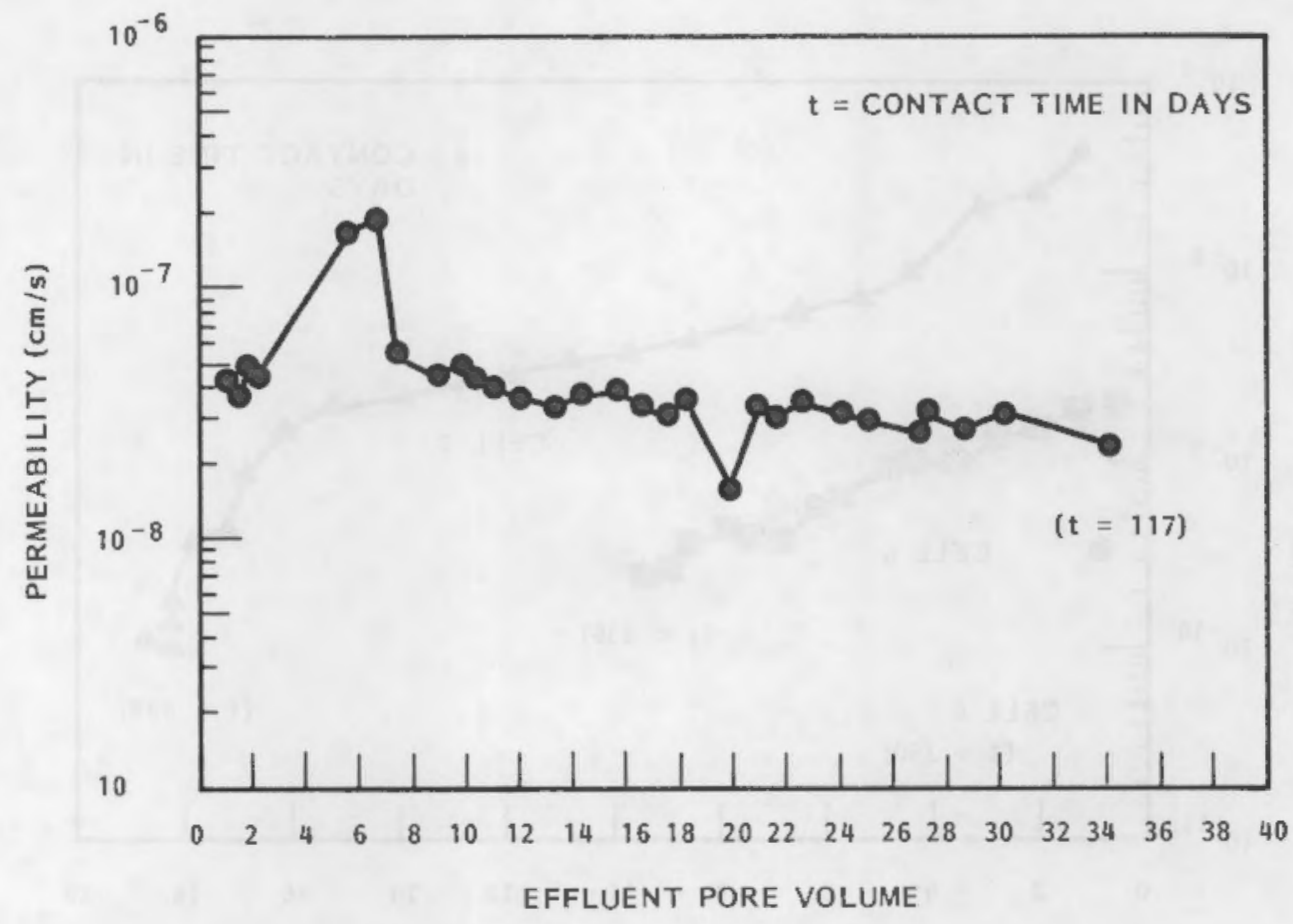

FIGURE 2.9. Permeability of the Lucky Mc Overburden Versus Pore Volumes of Effluent 


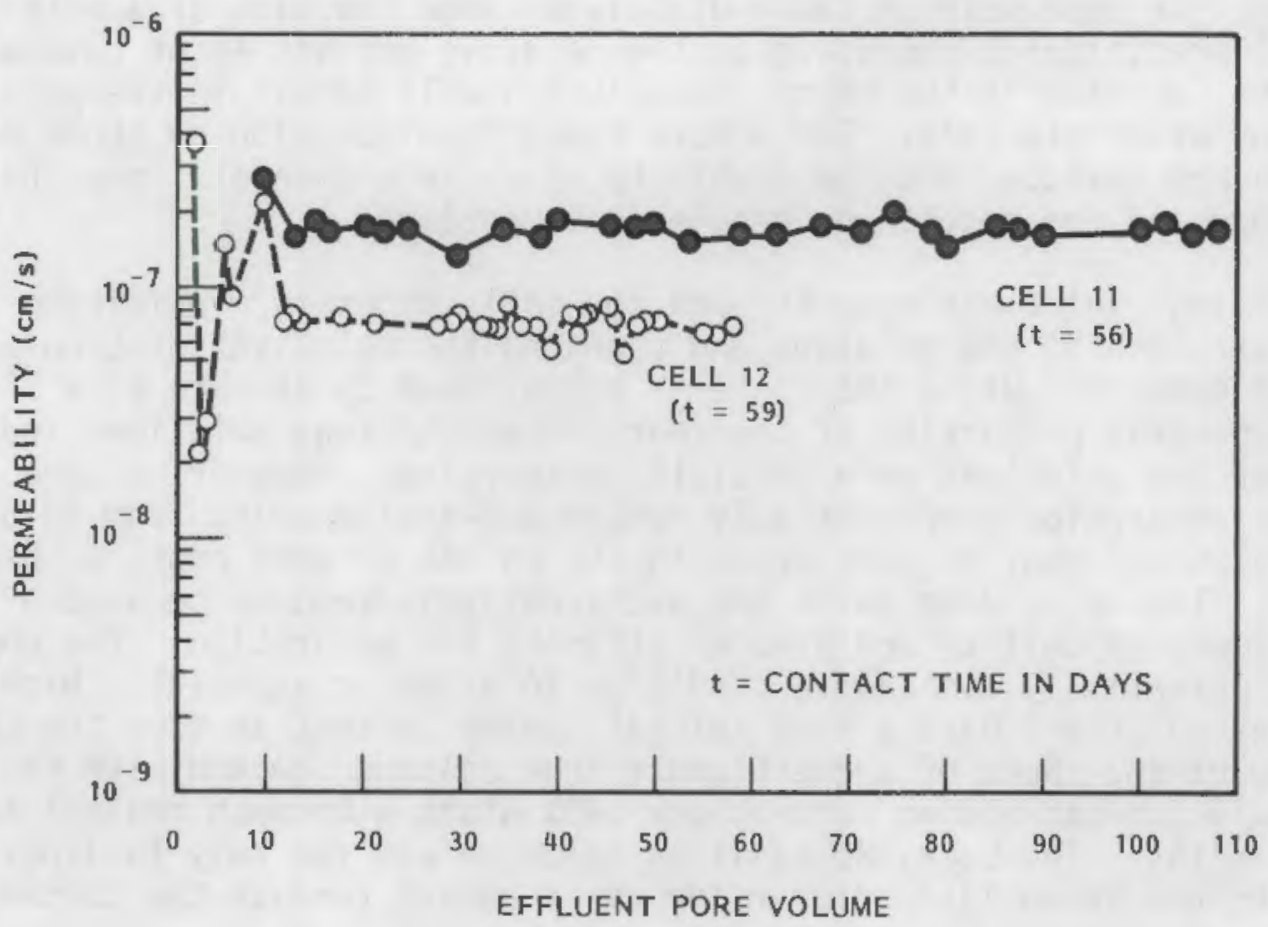

FIGURE 2.10. Permeability of the Dawn Overburden Material Versus Pore Volumes of Effluent

Two intertwined mechanisms could help account for the decreases in permeability that were generally observed when low $\mathrm{pH}$, high ionic strength, high sulf ate tailings solutions were allowed to contact clay liners and other geologic materials. First, precipitation of minerals due to the increase in pH, brought about by the buffering capacity of the soil, could result in pore plugging, thus decreasing permeability. Second, soil swelling and dispersion and def locculation of clay particles could result in decreases in hydrautic conductivity or permeability. It will be explained in succeeding paragraphs how these two mechanisms are related.

Many minerals become less soluble as the $\mathrm{pH}$ of their aqueous environment is increased. This is explained more fully in the geochemical modeling section, but, in general, precipitation of these minerals can occur as the $\mathrm{pH}$ rises assuming that the given dissolved constituents are sufficiently close to their saturation concentrations at the lower pH values. Dissolution of some soil minerals, such as calcium carbonate, takes place concurrently with the precipitation reactions that occur. Calcium carbonate dissolves, when contacted by the acidic solutions, according to Equation 1:

$$
\mathrm{CaCO}_{3}+2 \mathrm{H}^{+} \leftrightharpoons \mathrm{Ca}^{2+}+\mathrm{H}_{2} \mathrm{O}+\mathrm{CO}_{2}
$$

The calcium released into solution can result in the precipitation of gypsum since the tailings solutions tend to be in equilibrium with gypsum initially. 
Even though, for each mole of $\mathrm{CaCO}_{3}$ dissolved, some fraction of a mole of gypsum will precipitate, depending on the relative activities of calcium and sulfate, the increase in the $\mathrm{pH}$ of the solution will result in the precipitation of many other minerals. For a more complete discussion on those minerals expected to precipitate, and the stability of various minerals, see the section on mineralogy and the section on geochemical modeling.

As tailings solutions move through the soil, minerals precipitate lowering the ionic strength of the solution and changing the relative solution percentage of each element. Using the criteria established by Sherard et a1. (1976) for the dispersive properties of the four tested tailings solutions indicated that none of the solutions were initially dispersive. However, as precipitation and/or adsorption preferentially remove non-sodium salts from solution the tailings solutions $c$ an, at some point in the column or soil profile, become dispersive. The non-sodium salts are preferentially removed because of their generally lower solubility and greater affinity for adsorption. The opportunity for a potentially dispersive condition to exist is especially high when the tailings solutions have a high initial sodium content as does the Lucky Mc tailings solution. Some of the effluents from columns leached with the Lucky Mc solution had sodium percentages $>40 \%$ along with much reduced total dissolved solids. The Lucky Mc tailings solution was the only tailings solution that became potentially dispersive as it passed through the column.

In soils containing appreciable amounts of smectite, McNeal et al. (1966) speculated that the predominant mechanism causing the hydraulic conductivity to decrease was clay swelling. Smectite has been identified in the Morton Ranch clay liner by $X$-ray diffraction (see section on mineralogy). The clay sized fraction of the Morton Ranch clay liner also contains illite and kaolinite along with other minerals noted in Section 4.0. The Lucky Mc overburden is composed of eight minerals (Erikson and Sherwood 1982) among which kaolinite, illite and smectite have been identified. Cass and Sumner (1982) mention that sensitivity to excess sodium is mainly due to such soil properties as clay content, bulk density, and clay mineralogical composition. There is an inverse relationship between clay content and bulk density and the observed permeability of soil-liner materials. Those soils having large quantities of 2:1 layer expanding silicate minerals tend to be more sensitive to high sodium percentages than those containing illite, kaolinite, iron oxides, and amorphous material. The precipitation of minerals such as amorphic ferric hydroxide, alunite, and aluminum hydroxy sulfate should help impede any dispersive tendencies. Any dispersion occurring in these columns involved a short range migration of particles as no clay particles were visually observed in the eff luents.

\subsection{SUMMARY OF PERMEABILITY TESTS}

Liner failure (i.e., an increase in permeability of the liner material) has not been found to be a problem when acidic tailings solutions encounter liner and overburden materials over a period of almost 3 years. On the contrary, the liner material and two of three overburden materials showed a decrease in permeability with time. Reactions that can occur, such as precipitation, deflocculation, swelling, etc. tend to decrease the permeability 
and thus increase the stability of the liner materials. The high permeability observed in the Morton Ranch coarse overburden $c$ an be explained by the high sand content, low percentage of fines ( $<25 \%$ passing a $53 \mu \mathrm{m}$ sieve), and resultant large pore sizes. Permeability increases in this material occurred only after the effluent $\mathrm{pH}$ dropped to values approaching the influent $\mathrm{pH}$. High flow rates of low pH solution may have washed fine particulates from the pores of this coarse sediment causing the increase in permeability.

These tests demonstrate that the materials tested that contain over $30 \%$ clay are able to maintain their permeabilities at the initial values or lower for extended periods when contacted with acidic tailings solutions and thus appear to be suitable materials for lining tailings impoundment ponds. The tests also demonstrate that soil compaction procedures which optimize density, and minimize channel cracks and fracture flow, can play an important role in maintaining acceptable permeabilities. The time dependence of the permeability changes was not predictable from the tests run to date. However, in model simulation these permeability changes should be accounted for when simulating both flow and contaminant migration from tailings disposal facilities. 



\subsection{NEUTRALIZATION BY GEOLOGIC SEDIMENTS}

As seen in Tables 3.1 and 3.2, the Morton Ranch overburden and liner materials have properties that enable them to impede chemical migration. Similar behavior was observed in the other tailings solutions/sediment interactions. As illustrated by these tables, one of the attenuation processes of the materials can be directly attributed to the change in $\mathrm{pH}$ that occurs when the tailings solutions contact liner and overburden materials that contain minerals, (e.g., carbonates) which buffer the system towards a significantly higher pH. The change in solution $\mathrm{pH}$ from 2.0 to nearly 8.0 greatly increases the hydroxide ion concentration, decreases the solubility of many solid phases and thus, precipitates many of the constituents of the tailings solutions. The chemical reactions that occur when this precipitation takes place are discussed more fully elsewhere (see Section 5.0). The effectiveness of the buffering capacity of the soils in lowering contaminant concentrations and the resultant high sorption that was experienced at high pH levels have all been documented previously (Gee et al. 1980a,b).

Eff luent $\mathrm{pH}$ as a function of time and the number of pore volumes eluted is shown in Figures 3.1 through 3.5. The cells that contained the Morton Ranch clay liner material leached with the synthetic tailings solutions (cells 1, 2 and 3) showed disparate pH front breakthroughs (Figure 3.1). The breakthrough occurred after between 1 to 7 pore values had been eluted. Cells 1 and 3 had $\mathrm{pH}$ values that did not change appreciably until more than 3 pore volumes had passed through the columns. For cell 2 the $\mathrm{pH}$ dropped rapidly after the first pore volume and was below pH 4 after 2 pore volumes of effluent, suggesting that flow was possibly occurring in cracks or channels or along the permeameter wall. This was the same cell that was recompacted after $\sim 4$ pore volumes had passed through the cell. This recompaction was accompanied by a concormitant decrease in the permeability by over an order of magnitude. After recompacting the liner material, the $\mathrm{pH}$ decreased slowly and in a manner similar to the other columns that were packed with the clay liner material. After almost 3 years of leaching the effluent from columns 1,2 and 3 still had not attained the influent $\mathrm{pH}$ levels, though the $\mathrm{pH}$ had dropped below 3 . This indicates a long term residual buffering capacity in the soil. The buffering mechanism will be discussed in subsequent paragraphs.

As indicated in Table 2.4 , only 0.89 pore volumes passed through cell 4 before flow through the cell ceased, so the $\mathrm{pH}$ of this effluent solution never dropped much below 8 . Both columns 5 and 6 achieved acid breakthrough at roughly 6 pore volumes. The $\mathrm{pH}$ of the effluent from these two columns slowly decreased, after the initial breakthrough, to values near 3 (Figure 3.2 ).

Columns 7,8 and 9 had $\mathrm{pH}$ front breakthroughs occurring after 2-3 pore volumes had passed through the overburden material (Figure 3.3).

The single column packed with the Lucky Mc overburden and leached with acid tailings liquor from the Lucky $M_{c}$ mine reached the $\mathrm{pH}$ front breakthrough after slightly over 30 pore volumes had passed through the column (Figure 3.4). 
TABLE 3.1. Analysis of the Eff luent Solution from Morton Ranch Clay Liner (Cell 1) Leached with Synthetic Tailings Solution $\left(\mathrm{pH}=2.0 \mathrm{Al}=595, \mathrm{Fe}=2,217\right.$, and $\left.\mathrm{SO}_{4}=13,000 \mathrm{mg} / 1\right)$

\begin{tabular}{|c|c|c|c|c|c|c|c|c|c|c|c|}
\hline ore Volume & 1.26 & 1.68 & 2.12 & 2.54 & 2.95 & 3.30 & 4.47 & 5.15 & 5.89 & 25.51 & \\
\hline $\mathrm{pH}$ & 7.7 & 7.9 & 7.8 & 7.7 & 7.8 & 5.7 & 4.0 & 4.3 & 3.8 & 3.35 & \\
\hline eme & & & & & $--m g /$ & & - & & & $-\infty$ & $\mathrm{DL}$ \\
\hline Al & $\mathrm{DL}^{(}$ & $\mathrm{DL}$ & DL & $\mathrm{OL}$ & $\mathrm{DL}$ & $\mathrm{OL}$ & 29 & 146 & 193 & 958 & 0.1 \\
\hline $\mathrm{Fe}$ & $\mathrm{DL}$ & $\mathrm{OL}$ & $\mathrm{OL}$ & DL & $\mathrm{DL}$ & 32 & 645 & 1312 & 1582 & 1510 & 0.1 \\
\hline $\mathrm{SO}_{4}$ & 2445 & 2340 & 2690 & 3444 & 3833 & 4714 & 7147 & 8304 & 7984 & 12,200 & 0.1 \\
\hline
\end{tabular}

(a) 8elow detection limit (OL)

TABLE 3.2. Analysis of Eff luent Solution from Morton Ranch Clay Liner (Cell 5) Leached with Highland Mill Tailings Solution $(\mathrm{pH}=1.8 \mathrm{Al}=600, \mathrm{Fe}=$ 2,215 , and $\mathrm{SO}_{4}=12,850 \mathrm{mg} / 1$ )

\begin{tabular}{|c|c|c|c|c|c|c|c|c|}
\hline Pore Volume & 1.35 & 3.46 & 5.54 & 6.24 & 7.91 & 8.89 & 10.39 & 11.17 \\
\hline $\mathrm{pH}$ & 8.2 & 8.0 & 4.8 & 4.2 & 3.8 & 3.53 & 3.70 & 3.42 \\
\hline lement & & & & $--n$ & le-- & & & - \\
\hline Al & $\mathrm{OL}^{(\mathrm{a})}$ & $\mathrm{OL}$ & $\mathrm{OL}$ & 47 & 167 & 392 & 564 & 703 \\
\hline $\mathrm{Fe}$ & DL & $\mathrm{DL}$ & 127 & 538 & 950 & 1330 & 1560 & 1720 \\
\hline $\mathrm{SO}_{4}$ & 2220 & 3704 & 7864 & 9492 & 12,192 & 13,900 & 14,800 & 10,100 \\
\hline
\end{tabular}

(a) Below detection limit (DL)

The $\mathrm{pH}$ values of the Dawn overburden eff luents dropped down very close to the inffluent $\mathrm{pH}$ with both columns having effluent $\mathrm{pH}$ values below 2.0 versus an inf luent $\mathrm{pH}$ of 1.8. Approximately 10 pore volumes passed through the columns before the pH front breakthrough was achieved (Figure 3.5).

There are numerous factors (e.g., carbonate and layered silicate dissolution and precipitation, aluminum and iron hydrolysis, oxidation of $\mathrm{Fe}, \mathrm{U}, \mathrm{V}$, and $\mathrm{Mn}$ and the adsorptive capacity of the soil) that can potentially affect the $\mathrm{pH}$ of the effluent from these column experiments. In many calculations involving the buffering capacity of the soil it is assumed, as a first approximation, that this buffering capacity is due entirely to the calcium carbonate content of the soil (Cherry et al. 1982, Shepherd and Cherry 1980). If one makes this assumption, and also assumes a neutralization of the influent solution to a pH around 7 , then the neutralization process involving $\mathrm{CaCO}_{3} \mathrm{can}$ be represented by the following reaction: 


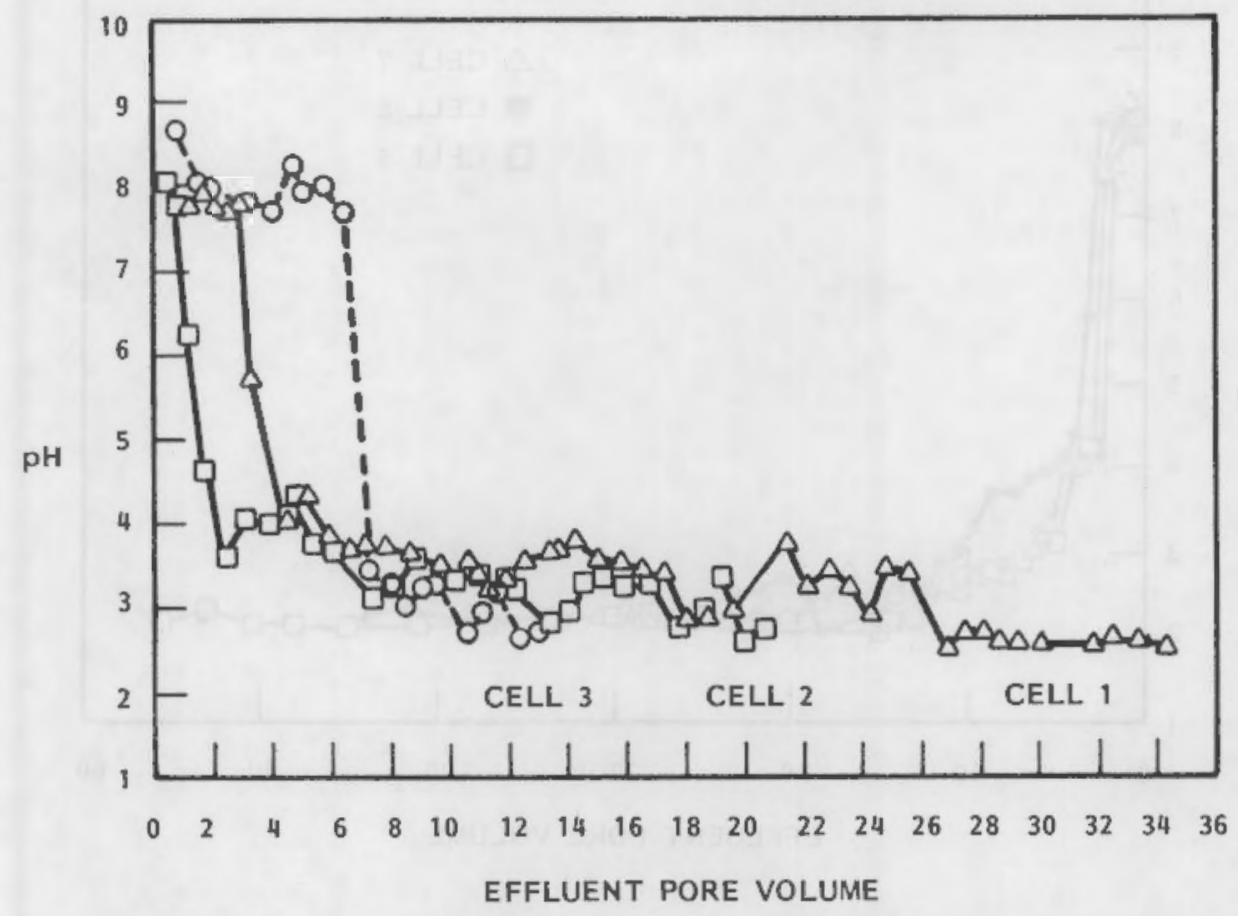

FIGURE 3.1. Plot of $\mathrm{pH}$ Versus Pore Volume for Cells 1,2 and 3

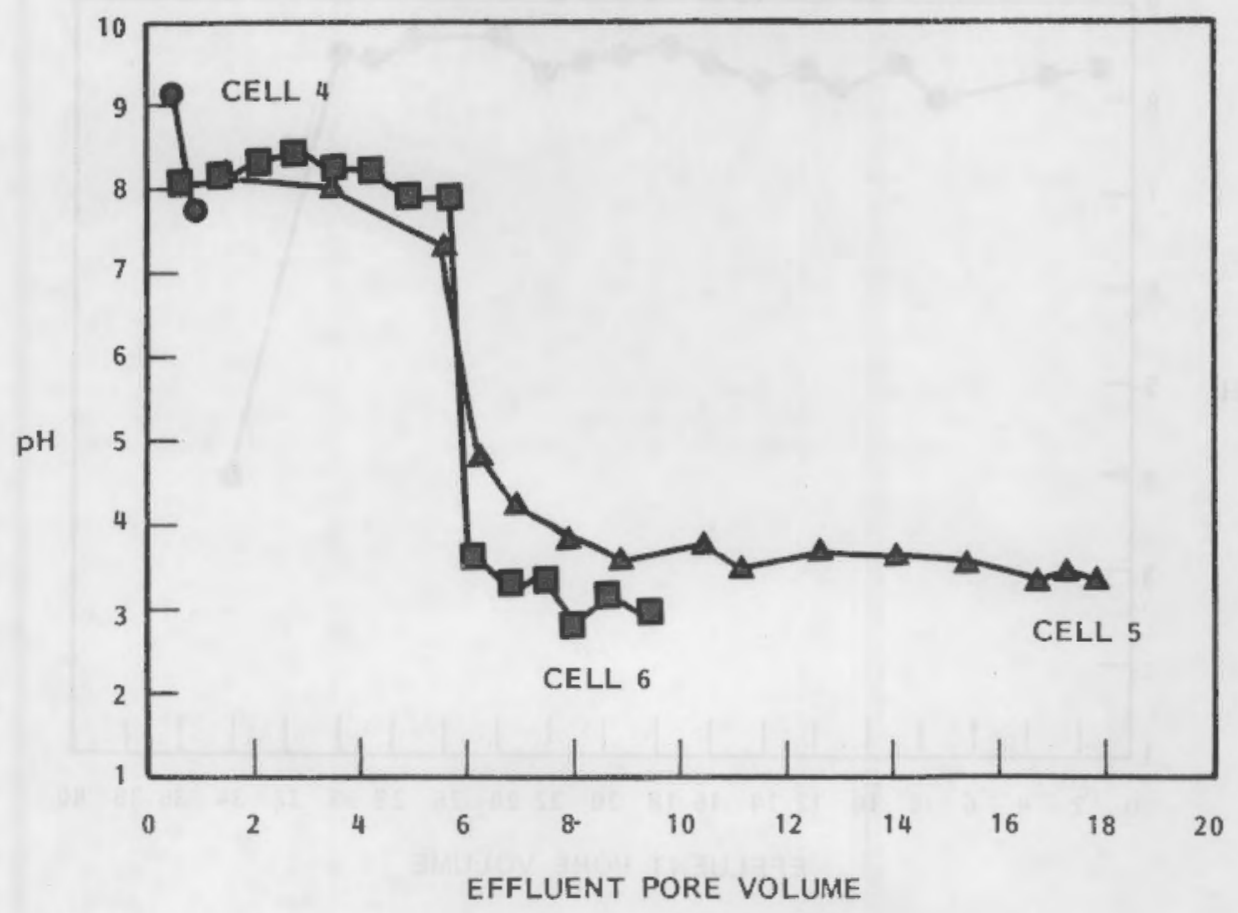

FIGURE 3.2. Plot of pH Versus Pore Volume for Cells 4,5 and 6 


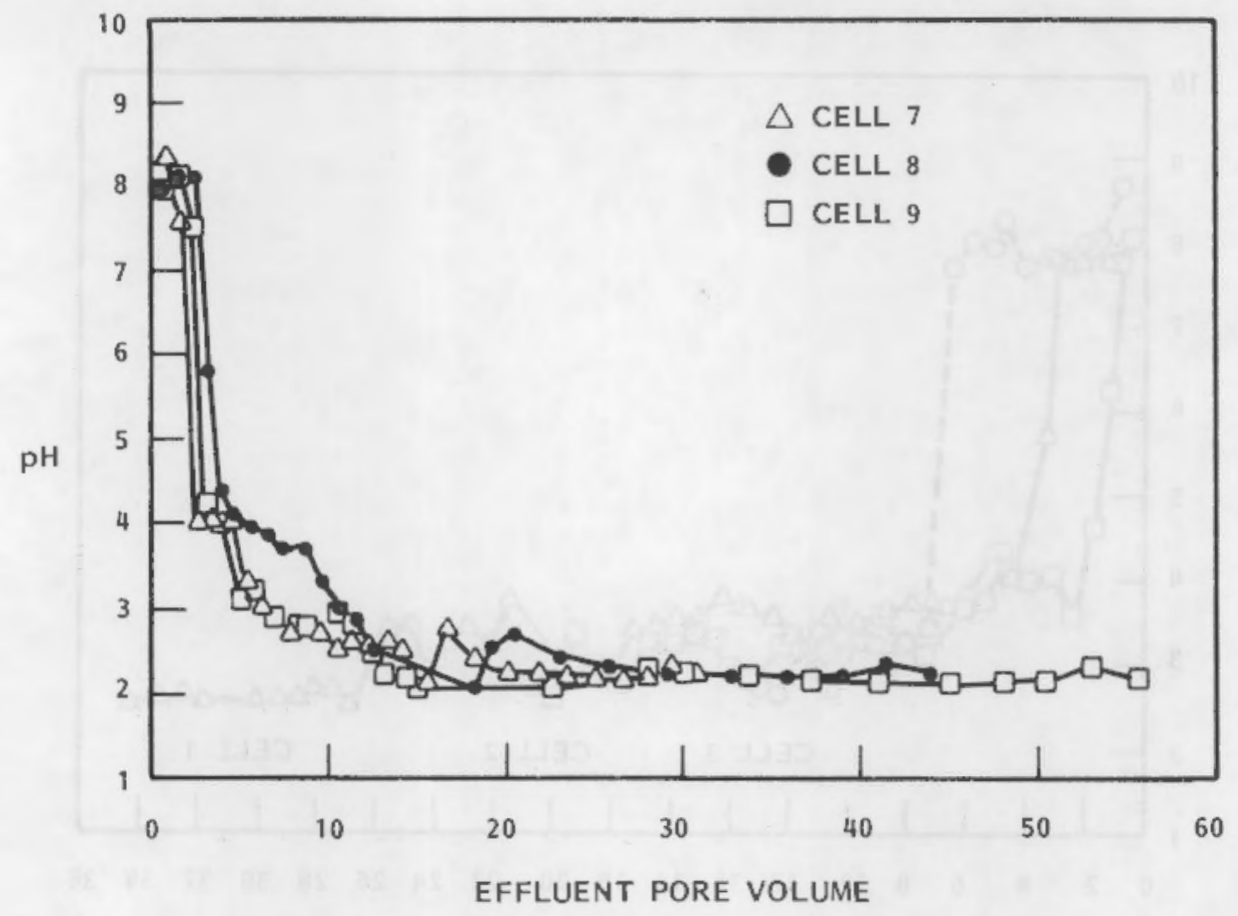

FIGURE 3.3. Plot of pH Versus Pore Volume for the Morton Ranch Overburden Material (cells 7, 8 and 9)

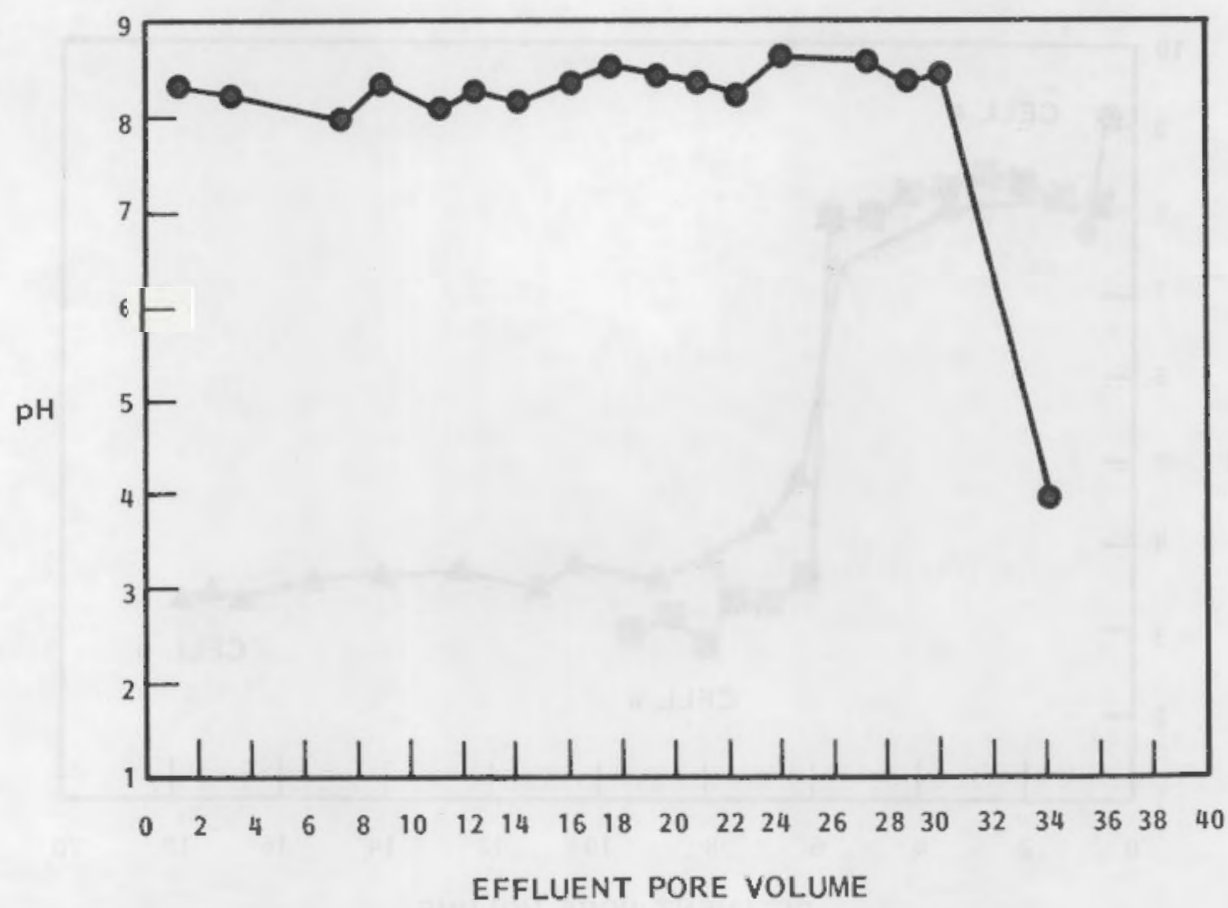

FIGURE 3.4. Plot of pH Versus Pore Volume for the Lucky Mc Overburden (cell 10) 


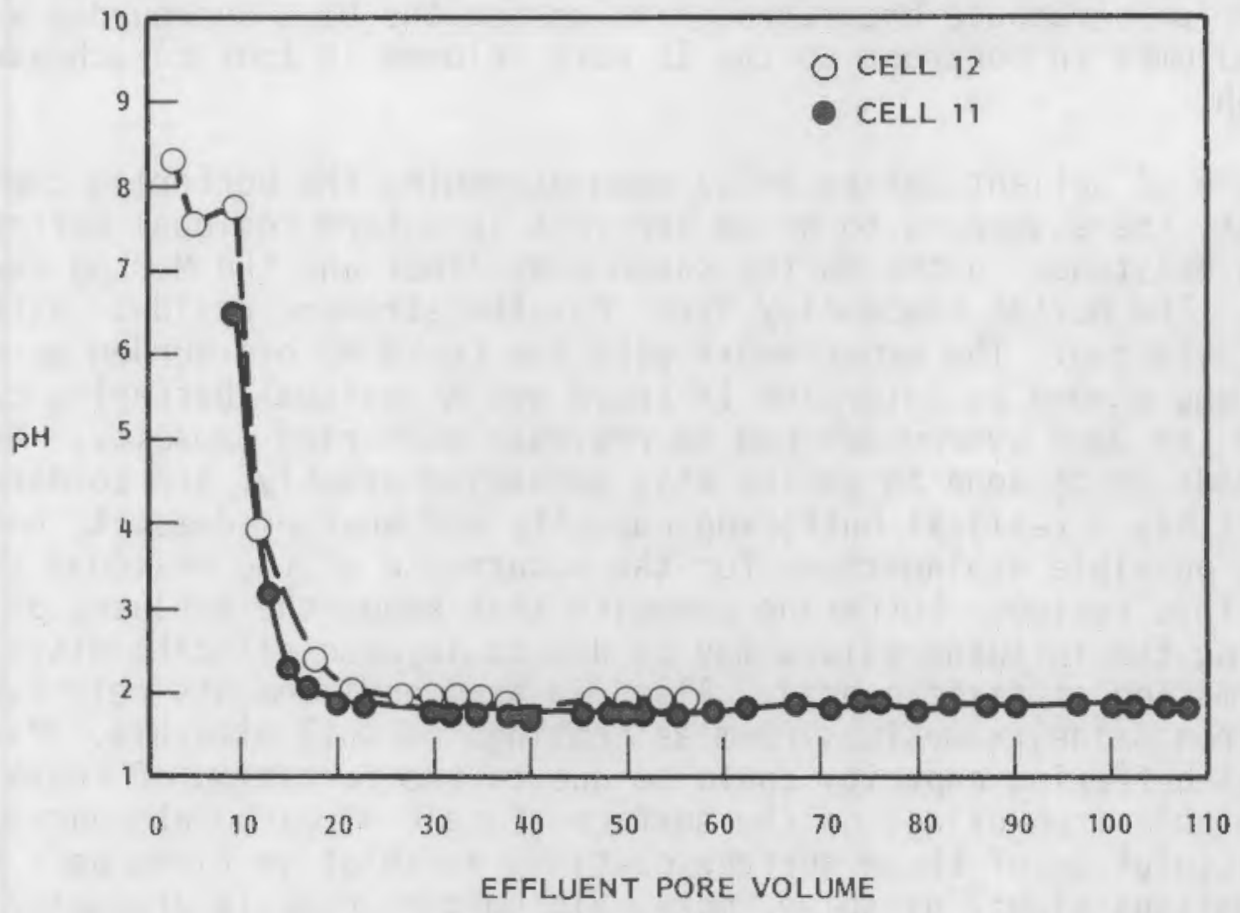

FIGURE 3.5. Plot of pH Versus Pore Volume for the Dawn Overburden Material (cells 11 and 12)

$$
\mathrm{H}^{+}+\mathrm{CaCO}_{3} \leftrightharpoons \mathrm{HCO}_{3}^{-}+\mathrm{Ca}^{2+}
$$

where 1 mole of $\mathrm{CaCO}_{3}$ will neutralize 1 mole of hydrogen ions. We are also assuming that the total acidity of the solution comes from the measured activity of the hydrogen ion, which may not be the case, especially in uranium mill tailings solutions, where a large part of the total potential acidity may arise from such species as iron and aluminum.

Based on the data from Tables 2.1 and 2.3, solution data in Table 2.2 $(\mathrm{pH})$, and Equation 2, it should take 1.9 pore volumes to overcome the calcium carbonate buffering capacity of the clay liner that was used in columns 1 through 3. The experimental data show that roughly 3 pore volumes came through columns 1 and 3 before the $\mathrm{pH}$ front breakthrough took place. Columns 5 and 6 did not experience this breakthrough until about 6 pore volumes had gone through the columns, compared to the predicted value, based on the above stated assumptions, of 1.2. According to the $\mathrm{CaCO}_{3}$ content of the Morton Ranch overburden that was employed in columns 7-9 it should take about 8 pore volumes of solution to overcome the calcium carbonate buffering capacity of this soil. The actual breakthrough for these columns was achieved after between 2 and 3 pore volumes passed through the columns. The column packed with the Lucky Mc overburden has a predicted calcium carbonate breakthrough of around 
60 pore volumes and an actual breakthrough at about 30 pore volumes. The calculated calcium carbonate breakthrough value for the $D$ awn overburden was 0.76 pore volumes in contrast to the 10 pore volumes it took to achieve actual breakthrough.

A couple of salient points arise when examining the buffering capacity data. First, there appears to be an inherent long-term residual buffering capacity in existence in the Morton Ranch clay liner and the Morton Ranch overburden. The Morton Ranch clay liner has the stronger residual buffering capacity of the two. The experiments with the Lucky Mc overburden were not continued long enough to determine if there was a residual buffering capacity present and the Dawn overburden had no residual buffering capacity. More research needs to be done to define this mechanism exactly, and to determine why one soil has a residual buffering capacity and another doesn't, but there are several possible explanations for the occurrence of the residual buffering capacity. This residual buffering capacity that keeps the eff luent pH values from reaching the influent values may be due to layered silicate dissolution and the formation of silicic acid. Also, in arid environments relatively insoluble iron oxides sometimes form as coatings on soil minerals. Part of the residual buffering capacity could be due to the formation of these relatively insoluble iron oxides on the surface of calcium carbonate particles and the slow dissolution of these surface coatings as solution flows past them. As these coatings slowly dissolve, more calcium carbonate is gradually made available for buffering of the soil acidity. Another possible mechanism for this residual buffering capacity is the dissolution of minerals that had previously precipitated at high pH values. For example, the aluminum and iron in the tailings solutions hydrolyze and precipitate as amorphic ferric hydroxide $\left[\mathrm{Fe}(\mathrm{OH})_{3} \mathrm{~A},(\mathrm{~A}=\right.$ amorphic $\left.)\right]$ and aluminum hydroxide $\left[\mathrm{A} 1(\mathrm{OH})_{3} \mathrm{~A}\right]$ releasing hydrogen ions into solution according to reactions 3 and 4

$$
\begin{aligned}
& \mathrm{Fe}^{3+}+3 \mathrm{H}_{2} \mathrm{O} \leftrightharpoons \mathrm{Fe}(\mathrm{OH})_{3}+3 \mathrm{H}^{+} \\
& \mathrm{Al}^{3+}+3 \mathrm{H}_{2} \mathrm{O} \leftrightharpoons \mathrm{Al}(\mathrm{OH})_{3}+3 \mathrm{H}^{+}
\end{aligned}
$$

As the $\mathrm{pH}$ drops to lower values, and the calcium carbonate dissolves and disappears from the soil, the iron and aluminum hydroxides previously precipitated from solution according to Equations 3 and 4 become more soluble at the lower $\mathrm{pH}$ values and begin to dissolve. This dissolution proceeds according to the reverse of reactions 2 and 3 (right to left) and, in the process, consumes hydrogen ions and buffers the soil against further decreases in $\mathrm{pH}$. J. F. Relyea (1982) recently demonstrated that there is no residual buffering capacity evidenced when $\mathrm{HCL}$ was used to titrate geologic materials as opposed to a prevalent residual buffering capacity, below $\mathrm{pH} 4.5$, when acidic tailings leachates containing high concentrations of aluminum were used. Thus, acidic tailings containing iron and aluminum have the capacity to precipitate and release hydrogen ions into solution as the $\mathrm{pH}$ rises and then may buffer the soil against further decreases in $\mathrm{pH}$ by dissolving (and consuming hydrogen ions) once the $\mathrm{pH}$ drops to around 4 . 
The second point that $c$ an be gleaned from examining the buffering capacity data, apart from the long-term residual buffering capacity observation, is that the assumption that the total acidity of the tailings solution corresponds to the measured $\mathrm{pH}$ and the total buffering capacity of the soil to the calcium carbonate content, according to Equation 2, is insufficient for explaining the observed $\mathrm{pH}$ front breakthroughs. The best estimator of $\mathrm{pH}$ breakthroughs for these columns came from considering the total acidity to be due to the total of the measured $\mathrm{pH}, \mathrm{Al}^{3+}$ and $\mathrm{Fe}^{3+}$ and the buffering capacity to be due to the calcium carbonate content of the soil plus the soils cation exchange capacity. (The $\mathrm{Fe}^{3^{+}}$may not contribute to the buffering capacity in reducing environments.) Using these parameters to calculate a total sediment buffering capacity and total solution acidity, the predictions of the $\mathrm{pH}$ front breakthroughs for columns 1 to 9 matched closely with observed breakthroughs but were off considerably (predictions too low) for columns 10 to 12 . See Section 5.0 for analytical chemistry on the effluents of selected permeability columns.

For a $1 \mathrm{~m}$ thick clay liner compacted similarly to the clay liner of columns 1-6 (Table 2.3) and assuming a constant pressure head gradient of 10 and permeability of $10^{-8} \mathrm{~cm} / \mathrm{s}$, we calculate less than 2 pore volumes of solution would flow through the clay liner in 20 years. This size of head gradient might exist in an evaporation pond that was constantly filled to a depth of $9 \mathrm{~m}$, but would be conservatively high, by a factor of 5 to 10 , for any pit tailings disposal alternatives (Nelson et al. 1980). Even with the low $\mathrm{CaCO}_{3}$ content $(0.04 \%)$ of the Morton Ranch clay liner it would take roughly 65 years, using the assumed values for hydraulic head and permeability, for the acid tailings liquor to overcome the buffering capacity of the liner and for the low $\mathrm{pH}$ front to move into the surrounding geologic media. Using the same hydraulic head and permeability in conjunction with the Pathfinder Lucky Mc overburden (3.98\% $\mathrm{CaCO}_{3}$ ) computes a time of approximately 330 years before the $\mathrm{pH}$ front would advance through a $1 \mathrm{~m}$ thick clay liner. Both of these breakthrough times are based on the actual column breakthrough data and not on calculations involving the calcium carbonate content of the soil. Imposing the same conditions on the Morton Ranch and Dawn overburdens would yield pH front breakthroughs of 33 and 110 years, respectively.

\subsection{SUMMARY OF NEUTRALIZATION TESTS}

Data suggest that the clay liners and overburden materials will provide a barrier to contaminant migration not only through their low permeabilities, but also by their buffering capacities (also see Nelson et al. 1980). The best predictions of $\mathrm{pH}$ front breakthroughs were obtained by considering the total acidity to be due to the total of the measured $\mathrm{pH}$, and $\mathrm{Al}^{3+}$ and $\mathrm{Fe}^{3+}$ concentrations and the buffering capacity to be due to the soils calcium carbonate content plus cation exchange capacity. The Morton Ranch clay liner and overburden exhibited a residual long-term buffering capacity below a $\mathrm{pH}$ of around 4 whch was able to maintain the effluent $\mathrm{pH}$ values at a higher level than the influent $\mathrm{pH}$ values. Further work needs to be done to explain the reactions and principles that account for the buffering capacities of the soils and liners but a dominant cause for the residual buffering capacity may be 
redissolution of $\mathrm{Al}$ and $\mathrm{Fe}$ amorphic hydrous oxides. A $1 \mathrm{~m}$ thick soil or liner with a calcium carbonate content as low as $4 \%$ should not only be able to impede the $\mathrm{pH}$ front advance into the surrounding geologic material for hundreds of years, but should also be able, based on empirical evidence, to neutralize the total acidity contained in most tailings ponds over their entire active lifetimes. 


\subsection{MINERALOGICAL STABILITY OF LINER MATERIALS}

\subsection{INTRODUCTION}

The evaluation of the mineralogical stability of liner materials has involved 3 studies: 1) batch-type experiments, 2) column-type experiments, and 3) a field study. All studies were conducted to determine the stability and potential mineralogic alteration of liner materials in contact with acidic tailings solutions. This was accomplished by determining the sediment (liner) mineralogy before and after contact with tailings solutions.

\subsection{MATERIALS AND METHODS}

In the batch-type experiments, mixtures of liner material and tailings solution were agitated in polyethylene bottles for periods up to 16 months. The three liner materials tested include: 1) a clay liner material from Morton Ranch, Wyoming, 2) Volclay ${ }^{\circledR} \mathrm{CS}-50$, a sodium-saturated bentonite, and 3) Volclay Saline Seal, a polymer-treated bentonite. Each of these clay materials was reacted separately with: 1) actual tailings solution (Exxon Highland Mill, Wyoming), 2) a synthetic tailings solution similar in chemistry to the Highland Mill solution (see Table 2.2), and 3) two $\mathrm{H}_{2} \mathrm{SO}_{4}$ solutions of $\mathrm{pH}=2$ and $\mathrm{pH}=0.5$.

The column-type experiments involved the flow of acidic tailings solution, under constant head conditions, through permeability columns packed with liner materials (see Section 2.0). One of these columns (column 5) was selected for dissection and mineralogic characterization. In column 5, acidic tailings solution from Highland Mill in Wyoming was allowed to flow through Morton Ranch clay liner over an 838 day period. At the conclusion of the experiment, the column was dissected and split into 5 sections and the mineralogy of each section identified.

In addition, a field investigation of evaporation pond No. 4 at the Lucky Mc site, Wyoming, was conducted. Samples were recovered to depths of up to $60 \mathrm{~cm}$ from 5 locations on the pond bottom. The mineralogy of selected samples was determined as a function of depth from the pond bottom.

\subsection{ANALYTICAL METHODS}

The mineralogy of all sediments was determined from bulk and/or clay-sized fractions using powder $X$-ray diffraction techniques. The clay-sized fractions of the sediments were separated from the bulk samples by sedimentation (Jackson 1956, 1979). Since a large fraction of the uncontacted sediments used in the batch tests were clay-sized $(<2 \mu \mathrm{m})$, the results reported are for clay-sized fractions only. For the column tests and the field study, X-ray results are presented for bulk sediment samples. Diffractograms were obtained using a Philips XRG $3500 \mathrm{X}$-ray difractometer and Cu-Ka radiation. Each sample was scanned at $2^{\circ} 2 \theta /$ min between $2^{\circ}$ and $60^{\circ} 2 \theta$.

Registered trademark of the American Colloid Co., 5100 Suffield Court, Skokie, Illinois. 
In samples containing a large proportion of clay minerals (samples from the batch tests), specific procedures for proper identification of various clay mineral species were utilized. These procedures include: 1) homoionic saturation of clays with magnesium and potassium (Brindley and Brown 1980), 2) organic saturation of the clays with ethylene glycol and glycerol (MacEwan 1961), and 3) obtaining X-ray diffractograms in controlled humidity environments (Brindley and Brown 1980, 0'Brien 1948).

\subsection{RESULTS AND DISCUSSION}

The results of the 2 experimental studies (batch and column experiments) and the field study will be discussed separately. The data are presented as a series of diffractograms comparing the mineralogies of uncontacted samples and samples reacted with the various tailings solutions.

\subsubsection{Batch-Type Experiments}

The mineralogical data obtained from interpretation of the diffractograms are summarized in Table 4.1. Figures 4.1 through 4.4 illustrate several X-ray diffraction patterns obtained for the reacted and unreacted clay liner materials used in the batch experiments. The X-ray data for the clay fraction of the unreacted CS-50 bentonite (Table 4.1, B1) and Saline Seal bentonite (Table $4.1, \mathrm{~S} 1$ ) suggest the only clay constituent is smectite $\left[(\mathrm{Na}, \mathrm{CA})_{0.33}\right.$ $\left.(\mathrm{Al}, \mathrm{Mg})_{2} \mathrm{Si}_{4} \mathrm{O}_{10}(\mathrm{OH})_{2} \cdot \mathrm{nH}_{2} \mathrm{O}\right]$ (Figure 4.1). The occurrence of the (101) ref lections of $\alpha$-quartz $\left(\mathrm{SiO}_{2}, d=3.34 \AA\right)$ and cristobalite $\left(\mathrm{SiO}_{2}, d=4.05 \AA\right)$ in these diffractograms implies the presence of a trace amount of these phases. The shifts of the (00l) reflections (Figures $4.1 \mathrm{a}$ and $4.1 \mathrm{~b}$ ) upon glycerol solvation clearly indicate the presence of swellable smectite. Similar shifts of the $(00 \ell)$ reflections are also observed in the Saline Seal sample (Figure 4.1c).

The uncontacted clay-sized fraction of the Morton Ranch clay liner consists of a mixture of quartz $\left(\mathrm{SiO}_{2}\right)$, kaolinite $\left[\mathrm{Al}_{2} \mathrm{Si}_{2} \mathrm{O}_{5}(\mathrm{OH})_{4}\right]$, illite $\left[\mathrm{K}(\mathrm{Al}, \mathrm{Mg}, \mathrm{Fe})_{2}(\mathrm{Si}, \mathrm{Al})_{4} \mathrm{O}_{10}(\mathrm{OH})_{2}\left(\mathrm{H}_{2} \mathrm{O}\right)\right]$, feldspar $\left[(\mathrm{K}, \mathrm{Na}, \mathrm{Ca})(\mathrm{Al}, \mathrm{Si})_{4} \mathrm{O}_{8}\right]$, and smectite (Table $4.1, \mathrm{C} 1$ ). Kaolinite and quartz are probably the most abundant minerals in this liner material. Smectite and feldspar are minor constituents.

In Figures 4.2 and $4.3, X$-ray diffractograms of unreacted bentonite samples are compared to diffractograms of samples contacted with the synthetic tailings solutions. Figure 4.4 illustrates data for the Morton Ranch clay liner reacted with a $\mathrm{H}_{2} \mathrm{SO}_{4}(\mathrm{pH}=2)$ solution.

The $X$-ray diffraction data from the batch-type experiments suggest:

1) one phase (smectite) present in the initial Morton Ranch clay liner may have been consumed by the acidic solutions, and 2) the initial phases present in the CS-50 and Saline Seal bentonites were not completely consumed by reaction with any of the acidic solutions. The initial mineral assemblage of the CS-50 and Saline Seal bentonite samples (smectite, quartz and cristobalite) remained unchanged after contact with all of the solutions, except for sample B4 (Table 4.1). In this sample, quartz was not detected. Quartz is present, 
TABLE 4.1. Mineralogy of Clay Liner Material from Batch Experiments

\begin{tabular}{|c|c|c|c|c|c|c|}
\hline $\begin{array}{l}\text { Sample } \\
\text { No.(a) }\end{array}$ & $\begin{array}{l}\text { Tailings } \\
\text { Solution (b) }\end{array}$ & $\begin{array}{c}\text { Initial } \\
\text { Solution } \\
\text { pH }\end{array}$ & $\begin{array}{c}\mathrm{pH} \\
\text { After } \\
\text { Six } \\
\text { Months } \\
\end{array}$ & $\begin{array}{l}\text { Final } \\
\mathrm{pH}(\mathrm{c})\end{array}$ & $\begin{array}{l}\text { Mineral Phases } \\
\text { Present (d) }\end{array}$ & $\begin{array}{c}\text { Experiment } \\
\text { Duration } \\
\text { (Days) } \\
\end{array}$ \\
\hline B1 & -- & - & --- & $\ldots$ & $S M, Q, C$ & - \\
\hline B2 & Highl and Mill & 1.8 & 2.2 & 1.9 & $S M, Q, J, C, A$ & 485 \\
\hline B3 & Synthetic & 2.0 & 2.5 & 2.7 & $S M, Q, C$ & 365 \\
\hline 84 & $\mathrm{H}_{2} \mathrm{SO}_{4}$ & 0.5 & --- & 0.5 & SM, C & 7 \\
\hline B5 & $\mathrm{H}_{2} \mathrm{SO}_{4}$ & 2.0 & --- & 7.5 & $S M, Q, C$ & 7 \\
\hline S1 & -- & - & --- & --- & $S M, Q, C$ & -- \\
\hline S2 & Highland Mill & 1.8 & 2.2 & 1.9 & $S M, Q, J, A, C$ & 485 \\
\hline $\mathrm{Cl}$ & - & -- & -- & --- & $Q, K, I, S M, F$ & -- \\
\hline $\mathrm{C} 2$ & Highland Mill & 1.8 & 2.4 & 2.0 & $Q, K, I, J, F, A$ & 485 \\
\hline $\mathrm{C} 3$ & Synthet ic & 2.0 & 2.4 & 2.6 & $Q, K, I$ & 365 \\
\hline C4 & $\mathrm{H}_{2} \mathrm{SO}_{4}$ & 0.5 & -- & 0.8 & $Q, K, K, S M$ & 7 \\
\hline C5 & $\mathrm{H}_{2} \mathrm{SO}_{4}$ & 2.0 & --- & 5.2 & $Q, K, I, S M$ & 7 \\
\hline
\end{tabular}

(a) Samples $\mathrm{B} 1, \mathrm{~S} 1$, and $\mathrm{Cl}$ are the initial, unreacted CS-50 bentonite (B), Saline Seal bentonite (S), and Morton Ranch Clay liner (C) materials, respectively.

(b) Liquid to solid ratio for all experiments was 10:1.

(c) $\mathrm{pH}$ of decanted solution at conclusion of experiment.

(d) $S M=$ smectite, $Q=$ quartz, $J=$ jarosite, $I=i 11$ ite, $K=$ kaolinite, $\mathrm{F}=$ feldspar, $C=$ cristobalite, $A=$ alunite.

however, in such small quantities in the initial bentonite samples (i.e., B1 and S1) that it may not be detected in any one random subsample. Simi lar sampling inconsistencies are evident in samples of Morton Ranch clay liner. The initial clay-sized fraction of the Morton Ranch sample contains small quantities of feldspar and smectite in the clay-sized fraction. Some of these phases (smectite) were not identified in the reacted samples (Table 4.1). In samples C2 and C3 (Table 4.1), however, smect ite may have been consumed in a reaction with the tailings solution. The disappearance of smectite in only these samples could simply be the result of the long duration of these experiments and the small quantity of smectite in the unreacted Morton Ranch samples. The quartz, kaolinite, and illite present in the initial Morton Ranch samples were identified in the liner material after reaction with all of the solutions. 


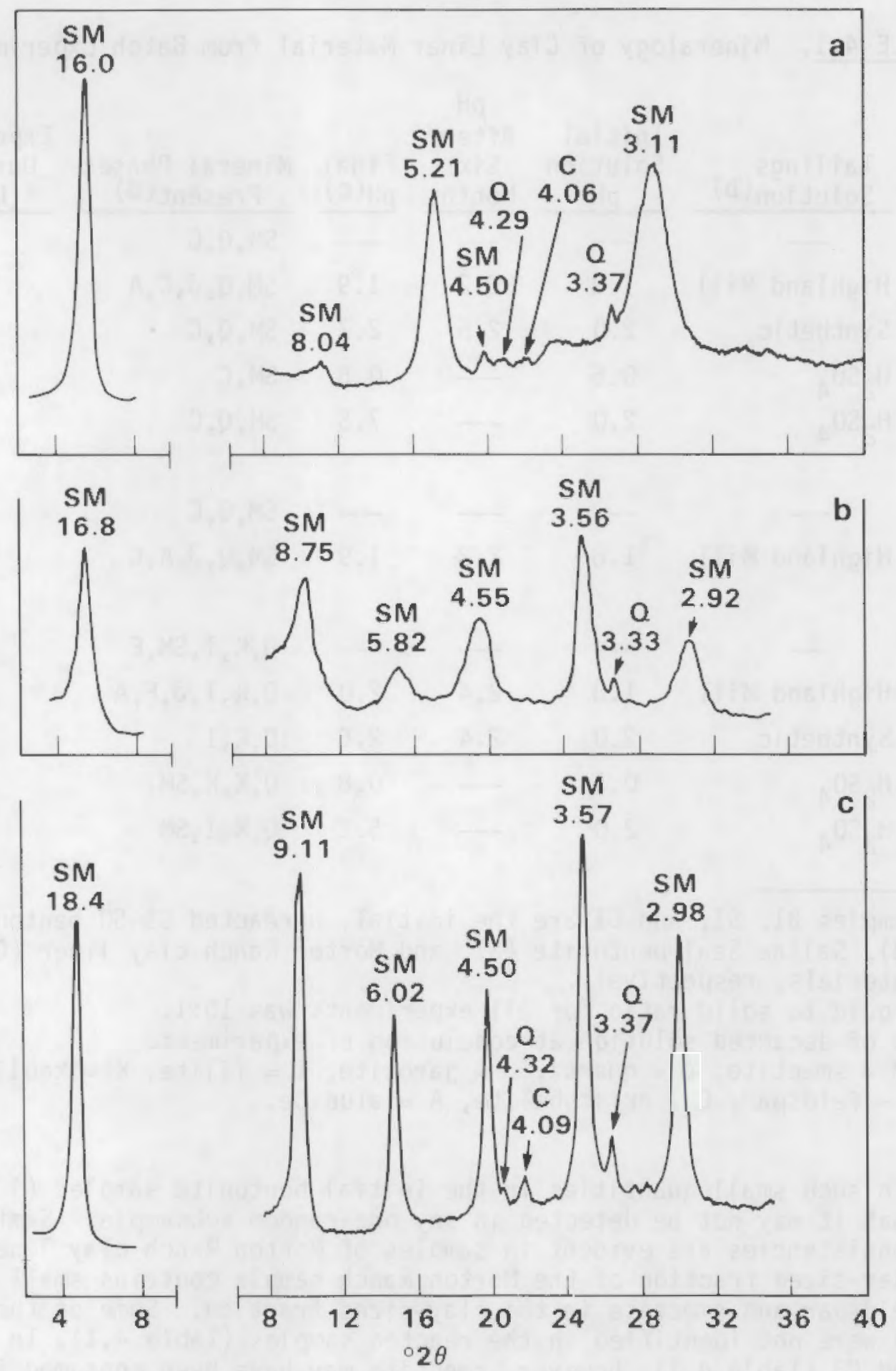

FIGURE 4.1. X-ray Diffraction Traces of Mg-Saturated Clay Fractions:

a) Unreacted CS-50 Bentonite, 56\% Relative Humidity,

b) Unreacted CS-50 Bentonite, Glycerol Saturated,

c) Unreacted Saline Seal Bentonite, Glycerol Saturated. Spacings in Angstroms. $S M=$ smectite, $Q=$ quartz, $\mathrm{C}=$ cristobalite. 


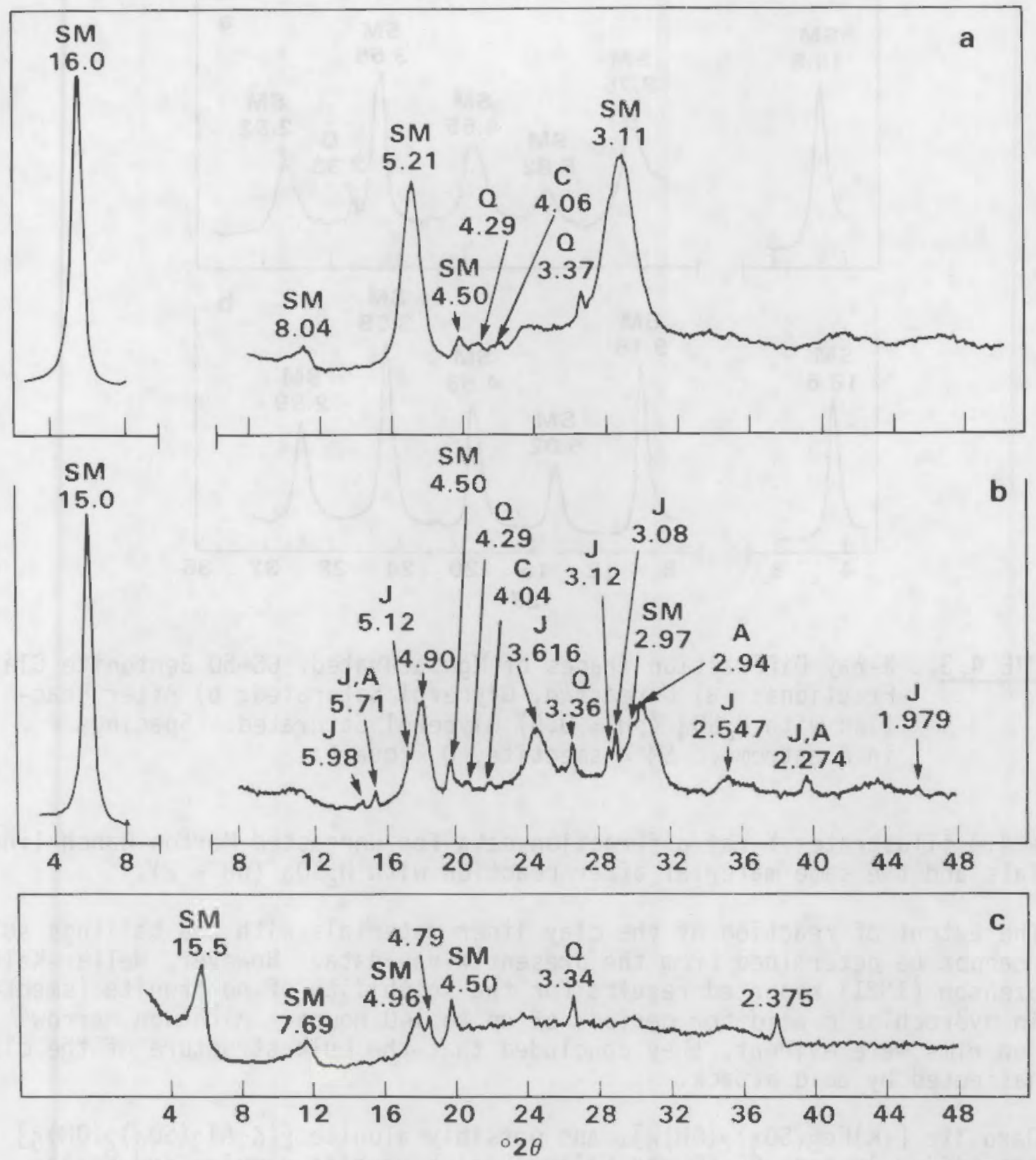

FIGURE 4.2. X-ray Diffraction Traces of Mg-Saturated, CS-50 Bentonite Clay Fraction: a) Unreacted, 56\% Relative Humidity; b) Reacted with Highland Mill Tailings Solution, 56\% Relative Humidity; c) Reacted with Synthetic Tailings Solution, $56 \%$ Relative Humidity. Spacings in Angstroms. $S M=$ smectite, $Q=$ quartz, $\mathrm{C}=$ cristobalite. 


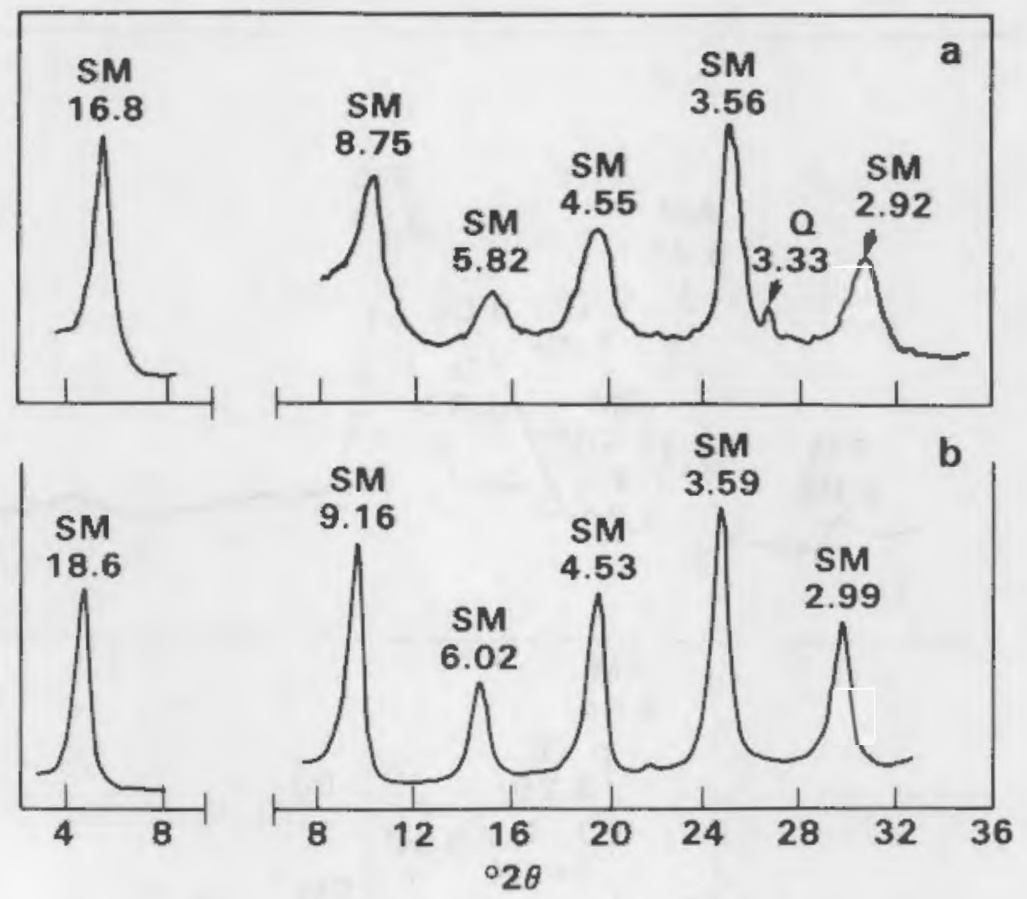

FIGURE 4.3. X-ray Diffraction Traces of Mg-Saturated, CS-50 Bentonite Clay Fractions: a) Unreacted, Glycerol Saturated; b) After Reaction with $\mathrm{H}_{2} \mathrm{SO}_{4}(\mathrm{pH}=0.5)$ Glycerol Saturated. Spacings in Angstroms. $S M=$ smectite, $Q=$ quart $z$.

Figure 4.4 illustrates $\mathrm{X}$-ray diffraction data for unreacted Morton Ranch 1 iner materials and the same material after reaction with $\mathrm{H}_{2} \mathrm{SO}_{4}(\mathrm{pH}=2)$.

The extent of reaction of the clay liner materials with the tailings solutions cannot be determined from the present X-ray data. However, Heller-Kallai and Rozenson (1981) reported results for the solubility of nontronite (smectite) in hydrochloric acid for periods of up to 140 hours. Although narrow reaction rims were evident, they concluded that the bulk structure of the clay was unaffected by acid attack.

Jarosite $\left[(\mathrm{K}) \mathrm{Fe}_{3}\left(\mathrm{SO}_{4}\right)_{2}(\mathrm{OH})_{6}\right]$, and possibly alunite $\left[(\mathrm{K}) \mathrm{Al}_{3}\left(\mathrm{SO}_{4}\right)_{2}(\mathrm{OH})_{6}\right]$ were identified in both CS-50 and Saline Seal bentonite samples and Morton Ranch clay liner samples reacted with the Highland Mill tailings solution (Figure $4.2 b$ ). The formation of al unite-group minerals may be the direct result of the supersaturation of the original Highland Mill tailings solution with respect to this mineral. Jarosite or alunite was not precipitated from the synthetic solution or $\mathrm{H}_{2} \mathrm{SO}_{4}$ solutions when reacted with any of the liner materials. 

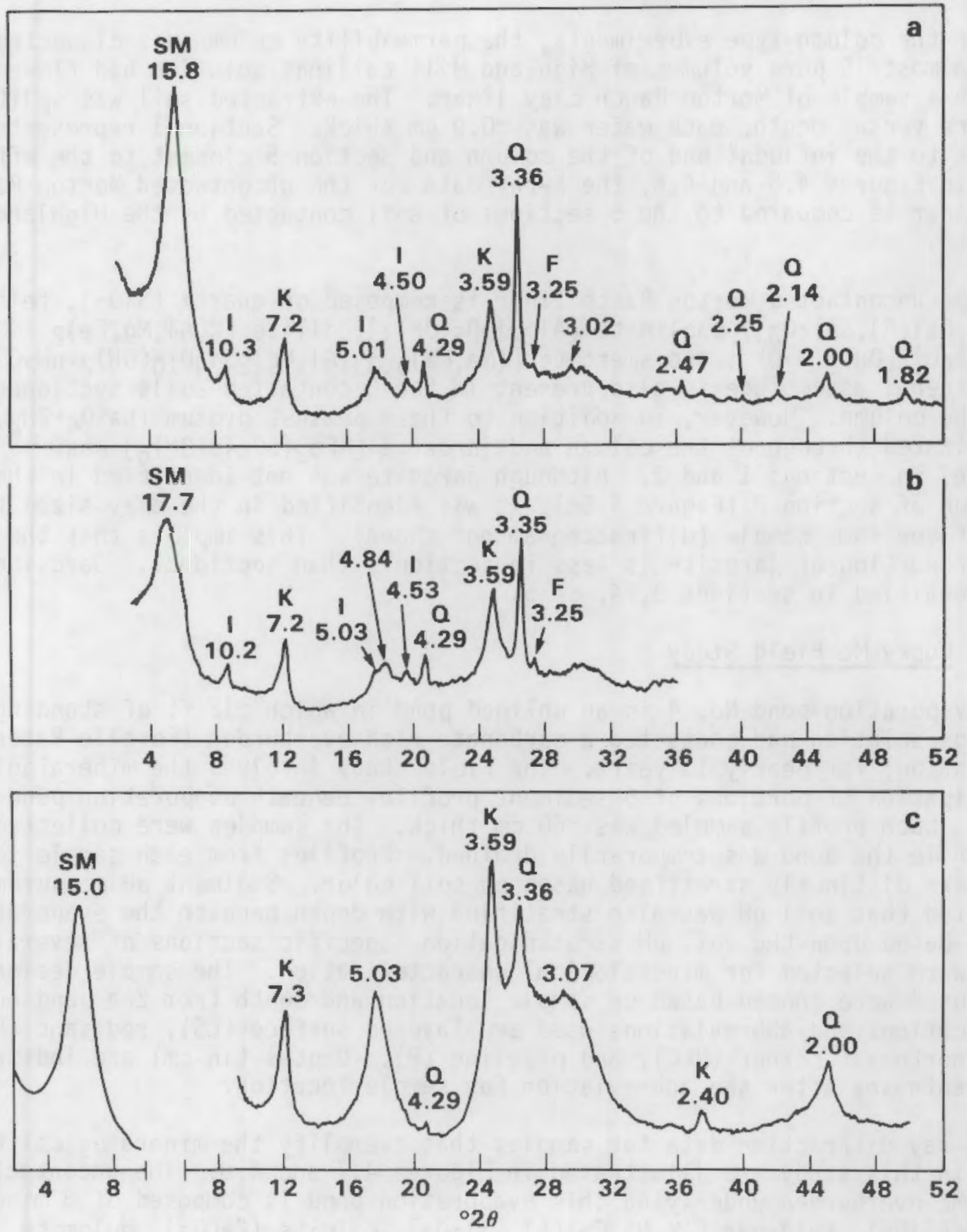

FIGURE 4.4. X-ray Diffraction Traces of Mg-Saturated, Morton Ranch Clay Liner Clay Fractions: a) Unreacted, 56\% Relative Humidity; b) Unreacted, Glycerol Saturated; c) Reacted with $\mathrm{H}_{2} \mathrm{SO}_{4}$ $(\mathrm{pH}=2), 56 \%$ Relative Humidity. Spacings in Angstroms. SM $=$ smectite, $I=$ illite, $K=$ kaolinite, $Q=$ quartz, $F=$ feldspar. 


\subsubsection{Column-Type Experiments}

In the column-type experiments, the permeability column was dissected after almost 19 pore volumes of Highland Mill tailings solution had flowed through a sample of Morton Ranch clay liner. The extracted soil was split into 5 wafers versus depth, each wafer was $\sim 0.9 \mathrm{~cm}$ thick. Section 1 represents soil closest to the influent end of the column and section 5 closest to the eff luent end. In Figures 4.5 and 4.6, the X-ray data for the uncontacted Morton Ranch clay liner is compared to the 5 sections of soil contacted by the Highland Mill solution.

The uncontacted Morton Ranch 1 iner is composed of quartz $\left(\mathrm{SiO}_{2}\right)$, feldspar $\left[(\mathrm{K}, \mathrm{Na}, \mathrm{Ca})(\mathrm{Al}, \mathrm{Si})_{4} \mathrm{O}_{8}\right]$, kaolinite $\left[\mathrm{Al}_{2} \mathrm{Si}_{2} \mathrm{O}_{5}(\mathrm{OH})_{4}\right]$, illite $\left[\mathrm{K}(\mathrm{Al}, \mathrm{Mg}, \mathrm{Fe})_{2}\right.$ $\left.(\mathrm{Si}, \mathrm{Al})_{4} \mathrm{O} 10(\mathrm{OH})_{2}\left(\mathrm{H}_{2} \mathrm{O}\right)\right]$, and smectite $\left[(\mathrm{Na}, \mathrm{Ca})_{0.33}(\mathrm{Al}, \mathrm{Mg})_{2} \mathrm{Si}_{4} \mathrm{O}_{10}(\mathrm{OH})_{2} \cdot \mathrm{nH}_{2} \mathrm{O}\right]$. This mineral assemblage is also present in the 5 contacted soils sectioned from the column. However, in addition to these phases, gyp sum $\left(\mathrm{CaSO}_{4} \cdot 2 \mathrm{H}_{2} \mathrm{O}\right)$ precipitated throughout the column and jarosite $\left[\mathrm{KFe}_{3}\left(\mathrm{SO}_{4}\right)_{2}(\mathrm{OH})_{6}\right]$ was

detected in sections 1 and 2. Although jarosite was not identified in the bulk fraction of section 2 (Figure $4.5 \mathrm{c}$ ), it was identified in the clay-sized fraction of the same sample (diffractogram not shown). This implies that the relative proportion of jarosite is less in section 2 than section 1 . Jarosite was not identified in sections 3,4 , or 5 .

\subsubsection{Lucky Mc Field Study}

Evaporation pond No. 4 is an unlined pond in which $12 \mathrm{ft}$ of standing tailings solution had contacted a carbonate-rich overburden (Forelle-Patent Association) for nearly 10 years. The field study involved the mineralogical investigation of portions of 5 sediment profiles beneath evaporation pond No. 4. Each profile sampled was $\sim 60 \mathrm{~cm}$ thick. The samples were collected in 1981 while the pond was temporarily drained. Profiles from each sample location were distinctly stratified based on soil color. Sediment pH measurements indicated that soil $\mathrm{pH}$ was also stratified with depth beneath the evaporation pond. Based upon the soil pH stratification, specific sections of several profiles were selected for mineralogical characterization. The sample designations used were chosen based on sample location and depth from the pond bottom: the locations and abbreviations used are layered surface (LS), red sand (RS), 7400 , northeast corner (NEC), and pipeline (P). Depths (in cm) are indicated in parentheses after the abbreviation for sample location.

$X$-ray diffraction data for samples that exemplify the mineralogical trends noted in this study are illustrated in Figures 4.7 and 4.8 . The uncontacted Lucky Mc overburden underlying this evaporation pond is composed of 8 minerals: quartz $\left(\mathrm{SiO}_{2}\right)$, feldspar $\left[(\mathrm{K}, \mathrm{Na}, \mathrm{Ca})(\mathrm{AI}, \mathrm{Si})_{4} \mathrm{O}_{8}\right]$, calcite $\left(\mathrm{CaCO}_{3}\right)$, do lomite $\left[(\mathrm{Ca}, \mathrm{Mg})\left(\mathrm{CO}_{3}\right)_{2}\right]$, gyp sum $\left(\mathrm{CaSO}_{4} \cdot 2 \mathrm{H}_{2} \mathrm{O}\right)$, kaolinite $\left[\mathrm{Al}_{2} \mathrm{Si}_{2} \mathrm{O}_{5}(\mathrm{OH})_{4}\right]$, illite $\left[\mathrm{K}(\mathrm{Al}, \mathrm{Mg}, \mathrm{Fe})_{2}(\mathrm{Si}, \mathrm{Al})_{4} \mathrm{O}_{10}(\mathrm{OH})_{2}\left(\mathrm{H}_{2} \mathrm{O}\right)\right]$, and a smectite-group mineral

$\left[(\mathrm{Na}, \mathrm{Ca})_{0.33}(\mathrm{Al}, \mathrm{Mg})_{2} \mathrm{Si}_{4} \mathrm{O}_{10}(\mathrm{OH})_{2} \cdot \mathrm{nH}_{2} \mathrm{O}\right]$. The $\mathrm{X}$-ray data presented in Figures 4.7 and 4.8 suggest that several mineralogical alterations occurred as the tailings solution permeated the sediments beneath the evaporation pond. The alterations reflect the changing chemical interactions with depth between the sediment and tailings solution. 

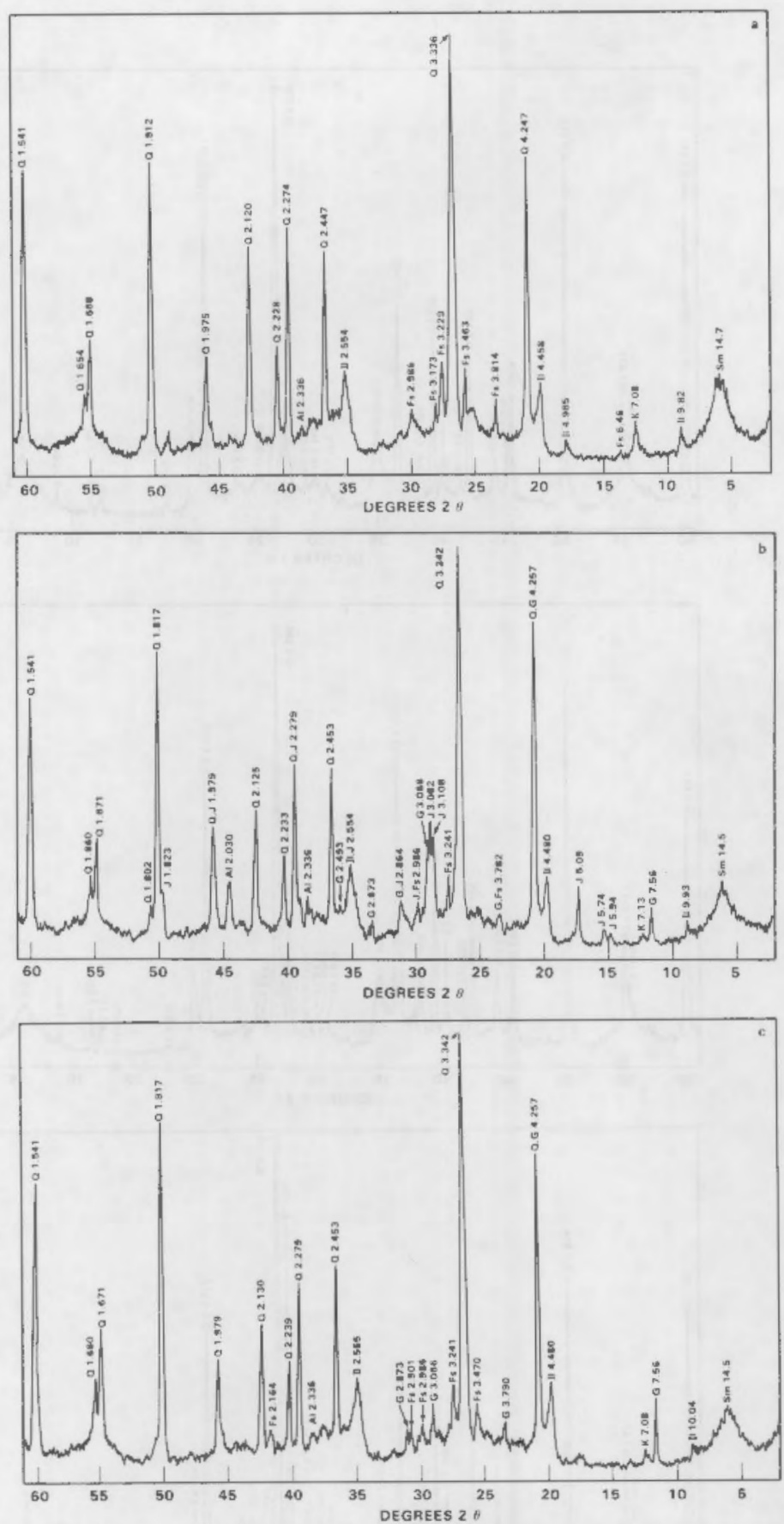

FIGURE 4.5. X-ray Diffraction Traces of Air-Dried, Bulk Samples of Morton Ranch Clay Liner: a) Uncontacted; b) Contacted, Section 1; c) Contacted, Section 2. Spacings in Angstroms. $S M=$ smectite, $I 1=$ illite, $K=$ kaolinite, $Q=$ quartz, $F s=$ feldspar, $J$ = jarosite, $G=$ gypsum, $A$ ) = al umi num ( holder). 

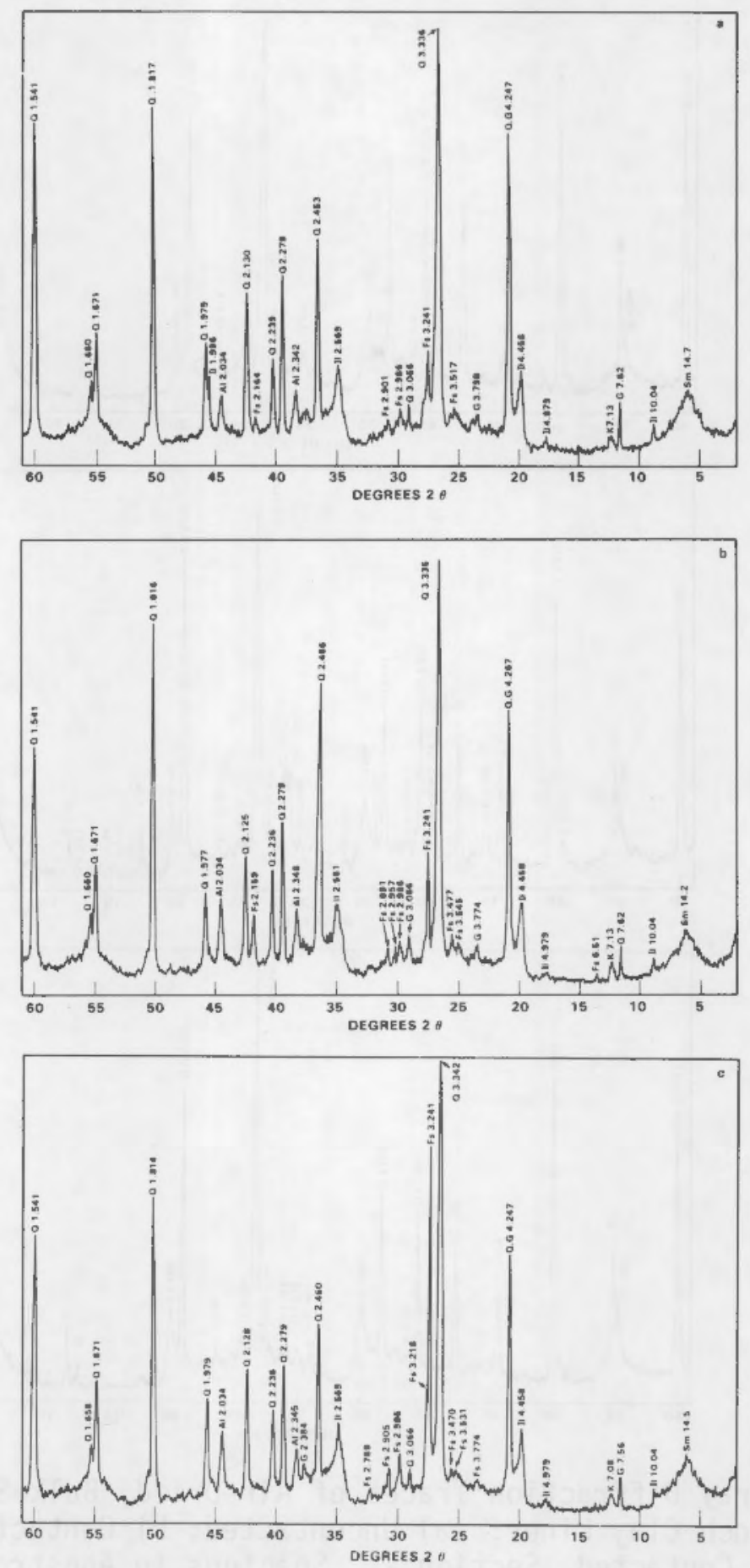

FIGURE 4.6. X-ray Diffraction Traces of Air-Dried, Bulk Samples of Morton Ranch Clay Liner: a) Contacted, Section 3; b) Contacted, Section 4 ; c) Contacted, Section 5 . Spacings in Angstroms. $S M=$ smectite, $I I=i l l i t e, K=$ kaolinite, $Q=$ quartz, $F S=$ feldspar, $G=$ gypsum, $A 1$ = aluminum ( sample holder). 
The mineralogical changes with depth are schematically illustrated in Figure 4.9. The width of the bars indicates qualitatively the relative increase or decrease in proportions of the various minerals as estimated from the peak intensities on the diffractograms. The shallower samples (LS, RS, 7400) are characterized by the complete dissolution of carbonates (calcite, dolomite) in the acidic solution and the precipitation of two sulfates, jarosite $\left[\mathrm{KFe}_{3}\left(\mathrm{SO}_{4}\right)_{2}(\mathrm{OH})_{6}\right]$ and gypsum $\left(\mathrm{CaSO}_{4} \cdot 2 \mathrm{H}_{2} \mathrm{O}\right)$. Although gypsum was present in the uncontacted Lucky Mc overburden (Figure $4.7 \mathrm{a}$ ), the number of peaks detected and the major peak intensities for gypsum significantly increased in the contacted samples (Figures $4.7 a, c$ and $4.8 \mathrm{a}-\mathrm{c}$ ). This suggests the formation of gypsum in the contacted soils in addition to that present in the uncontacted Lucky Mc overburden. Moreover, the data also indicate gypsum continues to form throughout the depth profile. Jarosite, however, is most concentrated in the shallower samples (LS) where the sediment and tailings solution coexist at low $\mathrm{pH}(\sim 3.0)$. The relative proportion of jarosite decreases with depth as the soil pH increases to 3.9 (RS sample) and 5.0 (7400 sample). Jarosite was not detected in deeper samples where the soil $\mathrm{pH}$ was $>5.0$. Jarosite, a common constitutent in acid sulfate soils, is considered thermodynamically more stable than amorphic ferric hydroxide $\left[\mathrm{Fe}(\mathrm{OH})_{3} \mathrm{~A}\right]$ at $\mathrm{pH}$ values $<6$, at sulfate and potassium activities commonly found in reacted tailings solutions (see Section 5.0, Figure 5.1a).

The other minerals (smectite, illite, kaolinite, quartz, and feldspar) present in the uncontacted Lucky Mc overburden were also detected in all the contacted samples. Several clay minerals, however, do not appear in the diffractograms presented in Figures 4.7 and 4.8. For example, smectite and/or kaolinite were not detected in bulk samples LS, 7400, P(25-30), and NEC(30-38). However, these clay minerals were identified in the clay-sized fractions of each of these samples (diffractograms not shown). They suggest that the clay minerals in the bulk samples are not present in sufficient quantity to be identified.

The carbonates, calcite and dolomite, reappear in the deepest sample $P(55-60)$ (Figure 4.8c). Moreover, the gypsum content decreases to a proportion similar to that of uncontacted Lucky Mc overburden. Based on the mineralogical and soil pH data, it appears that the 55 to $60 \mathrm{~cm}$ sample has not been mineralogically altered by the acidic tailings solution.

\subsection{CONCLUSIONS}

The major conclusion to be drawn from the three mineralogy studies is that the results of the laboratory experiments and field data are similar and complement the permeability and laboratory chemistry studies discussed in Sections 2.0 and 3.0 , and the geochemical modeling predictions discussed in Section 5.0. The mineralogical data suggest that the chemical stability of clay liners or native soil were not altered to a large extent when reacted with tailings solutions. In nearly all the cases discussed, the initial, uncontacted soil/liner mineralogies remained essentially unaltered after prolonged contact with acidic solutions. An obvious exception, however, is the dissolution of carbonates in the contacted Lucky Mc overburden. 

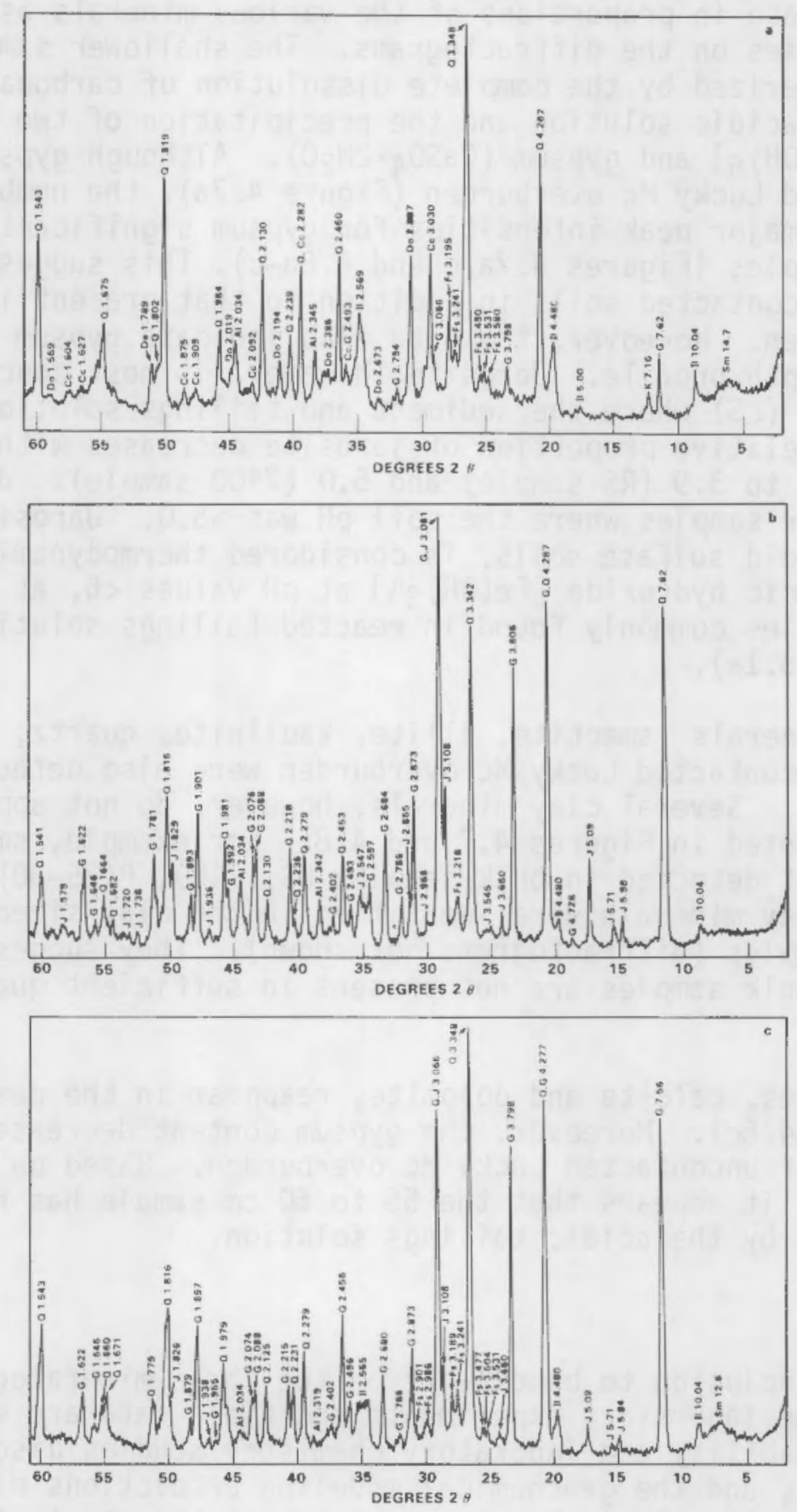

FIGURE 4.7. X-ray Diffraction Traces of Air-Dried, Bulk Samples of Lucky Mc Overburden: a) Uncontacted; b) Layered Surface (0 to $15 \mathrm{~cm}$ depth), Soil $\mathrm{pH}=3.0$; c) $7400(20$ to $25 \mathrm{~cm}$ depth), soil $\mathrm{pH}=$ 5.0. Spacings in Angstroms. $S M=$ smectite, $I 1=$ illite, $K=$ kaolinite, $Q=$ quartz, $F s=$ feldspar, $C C=$ calcite, $\mathrm{Do}=$ dolomite, $\mathrm{G}=$ gypsum, $\mathrm{J}=$ jarosite, $\mathrm{Al}=$ al umi num (sample holder). 

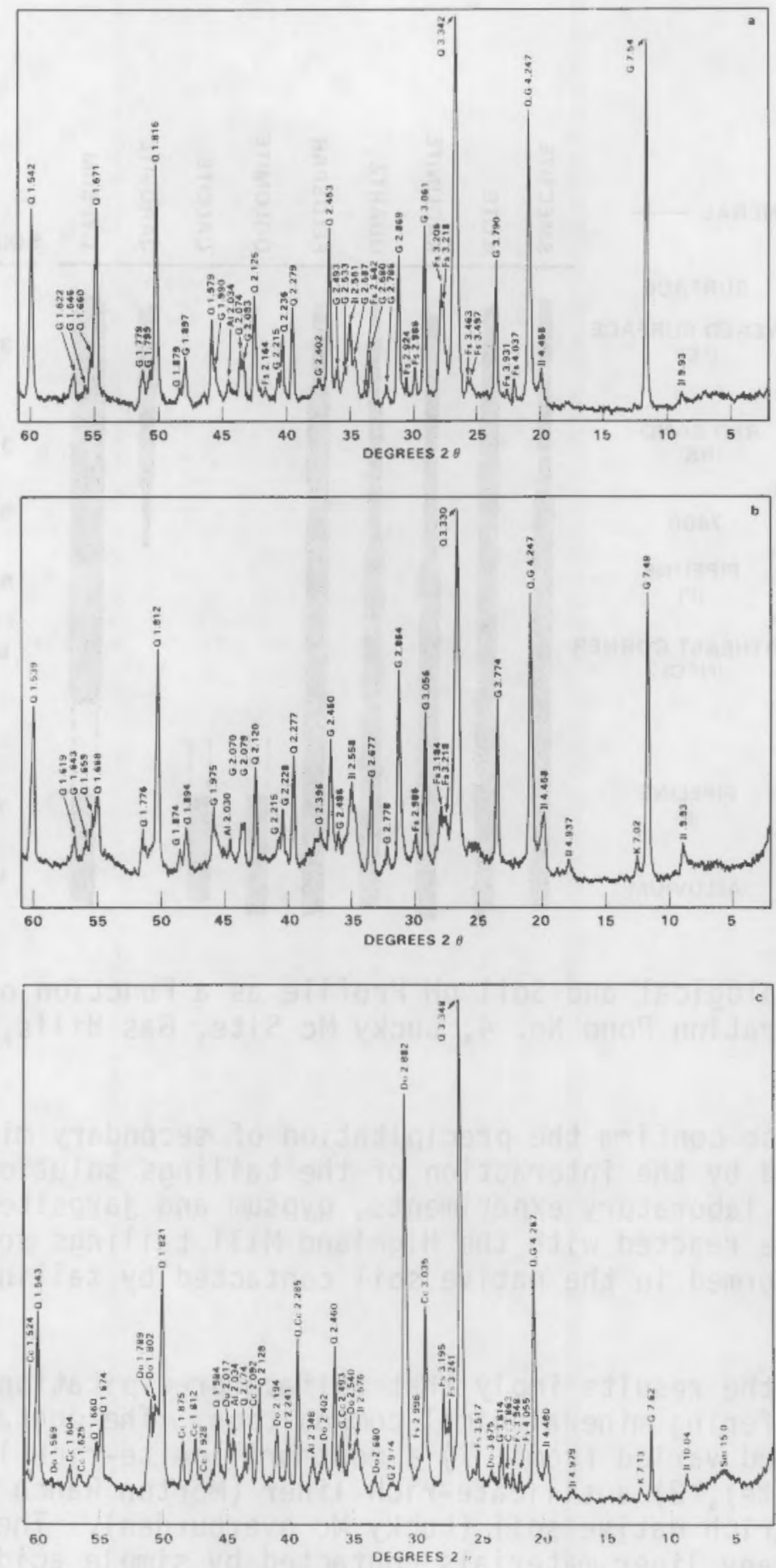

FIGURE 4.8. X-ray Diffraction Traces of Air-Dried, Bulk Samples of Lucky Mc Overburden: a) Pipeline (25 to $30 \mathrm{~cm}$ depth), Soil $\mathrm{pH}=6.2$;

b) Northeast Corner ( 30 to $38 \mathrm{~cm}$ depth), Soil pH $=6.8$;

c) Pipeline (55 to $60 \mathrm{~cm}$ depth), Soil pH =7.8. Spacings in Angstroms. $S M=$ smectite, $I I=i l l i t e, K=$ kaolinite, $Q=$ quartz, $F S=$ feldspar, $C_{C}=$ calcite, $D_{0}=$ dolomite, $\mathrm{G}=$ gypsum, $\mathrm{J}=$ jarosite, $\mathrm{Al}=$ aluminum (sample holder). 


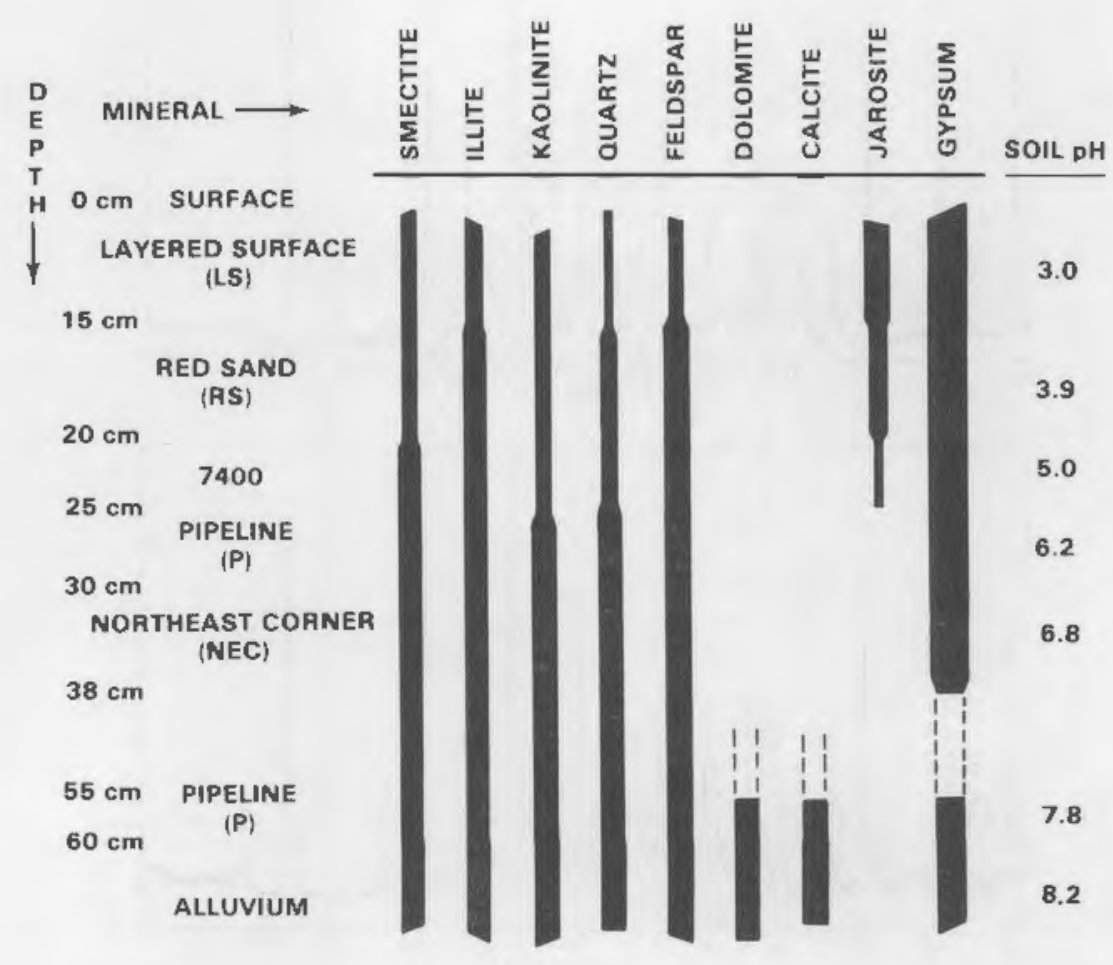

FIGURE 4.9. Mineralogical and Soil pH Profile as a Function of Depth Beneath Evaporation Pond No. 4, Lucky Mc Site, Gas Hills, Wyoming

The results also confirm the precipitation of secondary minerals (gypsum and jarosite) formed by the interaction of the tailings solution and soil/liner materials. In both laboratory experiments, gypsum and jarosite formed when liner materials were reacted with the Highland Mill tailings solution. These precipitates also formed in the native soil contacted by tailings solution at the Lucky Mc site.

Collectively, the results imply that sulfate precipitation occurred in soils of widely differing mineralogical composition. The contacted soils in which sulfates formed varied from: 1) a montmorillonite-rich liner (CS-50 and Saline Seal bentonite), 2) a silicate-rich liner (Morton Ranch clay liner), and 3) a carbonate-rich native soil (Lucky Mc overburden). The sulfates did not precipitate in any liner materials contacted by simple acids $\left(\mathrm{H}_{2} \mathrm{SO}_{4}\right)$ that lack the high concentrations of macro-ion constituents present in the natural tailings solutions. Both the Highand Mill and Lucky Mc tailings solutions (see Table 2.2 for chemical composition) have similar solution chemistries. Clearly, this emphasizes the importance of the chemical composition of the initial tailings solution in the formation of secondary minerals. 
The formation of secondary minerals, such as jarosite or other alunitegroup minerals, and gypsum, may be beneficial to the uranium mill tailings technology. These sulfates, if precipitated in quantity in the pores of a liner or soil, could potentially decrease the permeability of the liner and increase the liner performance in reducing contaminant migration. 


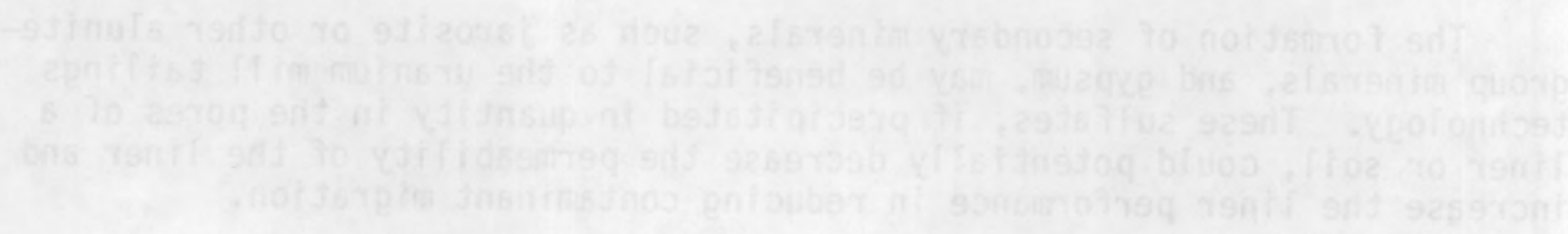




\subsection{GEOCHEMICAL MODELING}

\subsection{INTRODUCTION}

The ion speciation-solubility portions of the WATEQ3 (Ball et al. 1981) and MINTEQ (Felmy and Jenne 1982) geochemical computer models were used to model original aqueous solutions and solutions resulting from geologic materials contacted with acidic uranium mill tailings, synthetic mill tailings or $\mathrm{H}_{2} \mathrm{SO}_{4}$ in batch experiments; and acidic uranium mill tailings and synthetic tailings solutions leached through a clay liner in column experiments. The modeling results indicate solution species which are in apparent equilibrium with respect to particular solids. These solids provide potential solubility controls for their corresponding dissolved constituents. Knowledge of solubility controls for various solution species enables one to predict the maximum concentrations of these species when a specified solution composition contacts a given mineral assemblage.

This exploratory use of geochemical modeling has demonstrated its capability to test solubility hypotheses for liner materials reacted with tailings solutions and to guide the analyses of important constituents and parameters for these solutions. Geochemical modeling can be used, in parallel with characterization techniques for the solid phases, to support the presence of the solid phase and to guide the search for further solid phases. Geochemical modeling is also an effective tool in delineating the chemical causes for changes in permeability of liner materials.

\subsection{METHODS}

The ion speciation-solubility portions of the WATEQ3 and MINTEQ models were used to model the speciation of solutions in contact with clay liners and other geologic media. The MINTEQ geochemical code combines the 'best' features of its two predecessors, WATEQ3 and MINEQL (Westa11, Zachary and Morel 1976). In addition to an ion speciation-solubility submodel, MINTEQ contains mass transfer and adsorption capabilities. The WATEQ3 data base was incorporated into MINTEQ and then expanded with the inclusion of several additional solids. Also, certain trace elements not present in WATEQ3 ( $\mathrm{Ra}, \mathrm{Se}$, Th, and Mo) were added to the thermodynamic data base of the MINTEQ version used in this modeling study. MINTEQ has been verified against various geochemical models, including WATEQ3.

From the input of the solution analyses, the ion speciation submodels of WATEQ3 and MINTEQ compute the activities of complexed and uncomplexed cationic and anionic species, neutral ion-pairs, and the distribution of both cationic and anionic species among their redox states. The solubility submodels then calculate and compare these activity products (AP) to the solubility products (K) for the minerals and solids stored in the thermodynamic data bases of WATEQ3 and MINTEQ. This comparison of the activity versus solubility product tests the assumption that certain of the dissolved constituents in the aqueous solution are in equilibrium with particular solid phases. If the solution is 
computed to be at equilibrium $[\log (A P / K) \simeq 0]$ with a particular solid phase, then it is possible that the solid is precipitating or dissolving at a sufficient rate for it to be a control of the concentration of certain constituents in the solution. If the solution is computed to be oversaturated ( $\log \mathrm{AP} / \mathrm{K}>$ 0) with a certain solid phase, then it is inferred that kinetic and/or mineralogical factors usually prevent precipitation of the solid phase at a sufficient rate to significantly affect the concentration of dissolved constituents in the solution. A list of $\log (A P / K)$ values (or disequilibrium indices) are printed by WATEQ3 and MINTEQ for each modeled, aqueous solution. WATEQ3 was used to model the batch experiments and MINTEQ was used for the column experiments. As mentioned, MINTEQ was verified against WATEQ3 and contains an expanded WATEQ3 data base. This expanded data base gives one the capability to model the chemistry of additional elements that are of importance in uranium recovery operations.

Activity products of solution constituents are stated as being in equilibrium with a specified solid phase if the $\log (A P / K)$ for a particular solid phase $\mathrm{falls}$ within error bands established around the equilibrium ( $\log \mathrm{AP} / \mathrm{K}=$ 0) value. These error bands are computed by taking $+5 \%$ of the $\log K$ value of the particular solid and are indicated on the following figures by dashed lines on either side of the equilibrium line. This assumption is based upon the work of Jenne et al. (1980), who observed that the magnitude of scatter of the experimental data was proportional to the $\log$ of the solubility values. They concluded that $+5 \%$ of the $\log$ of the solubility product represented a working error band for Jetermining solubility hypotheses. The activity coefficients used in calculating the activity products were found by using either the extended Debye-Huckel equation with two adjustable parameters (Truesdell and Jones 1973) or, as an alternative, the Davies equation (Davies 1962). Both MINTEQ and WATEQ3 use these two models in their activity coefficient determinations. Neither activity coefficient model should be used at ionic strengths greater than sea water $(0.7 \mathrm{M})$. All modeled solutions in this study fall well within this range.

\subsection{SOLUTION ANALYSES}

Batch studies were conducted where Highland Mill (H.M.) tailings solutions, synthetic tailings solutions, and sulfuric acid were each separately reacted with: 1) a clay liner from Morton Ranch, Wyoming; 2) a sodium-saturated bentonite (Volclay $\left.{ }^{\circledR} \mathrm{CS}-50\right)$; and 3) Saline Seal ${ }^{\circledR 0}$ [a polymer-treated bentonite (see previous section on mineralogy and Gee et al. 1980a,b)]. The tailings, synthetic tailings, and $\mathrm{H}_{2} \mathrm{SO}_{4}$ solutions were reacted for

16 months, 12 months, and 1 week, respectively. The chemical analyses used as input into WATEQ3 include the compositions (see Table 5.1) reported for the aqueous solutions decanted and centrifuged from the batch experiments and for the original unreacted solutions. Modeling results were obtained for a total of seventeen solution analyses. The permeability columns modeled were columns 1 and 5 which contained the Morton Ranch clay liner reacted with the synthetic tailings solution and the H.M. tailings solution, respectively. A total

Registered trademark of the American Colloid Company, 5100 Suffield Court, Skokie, IL. 
TABLE 5.1. Chemical Analyses of Batch Solutions for Test Liner Materials and Original Solutions

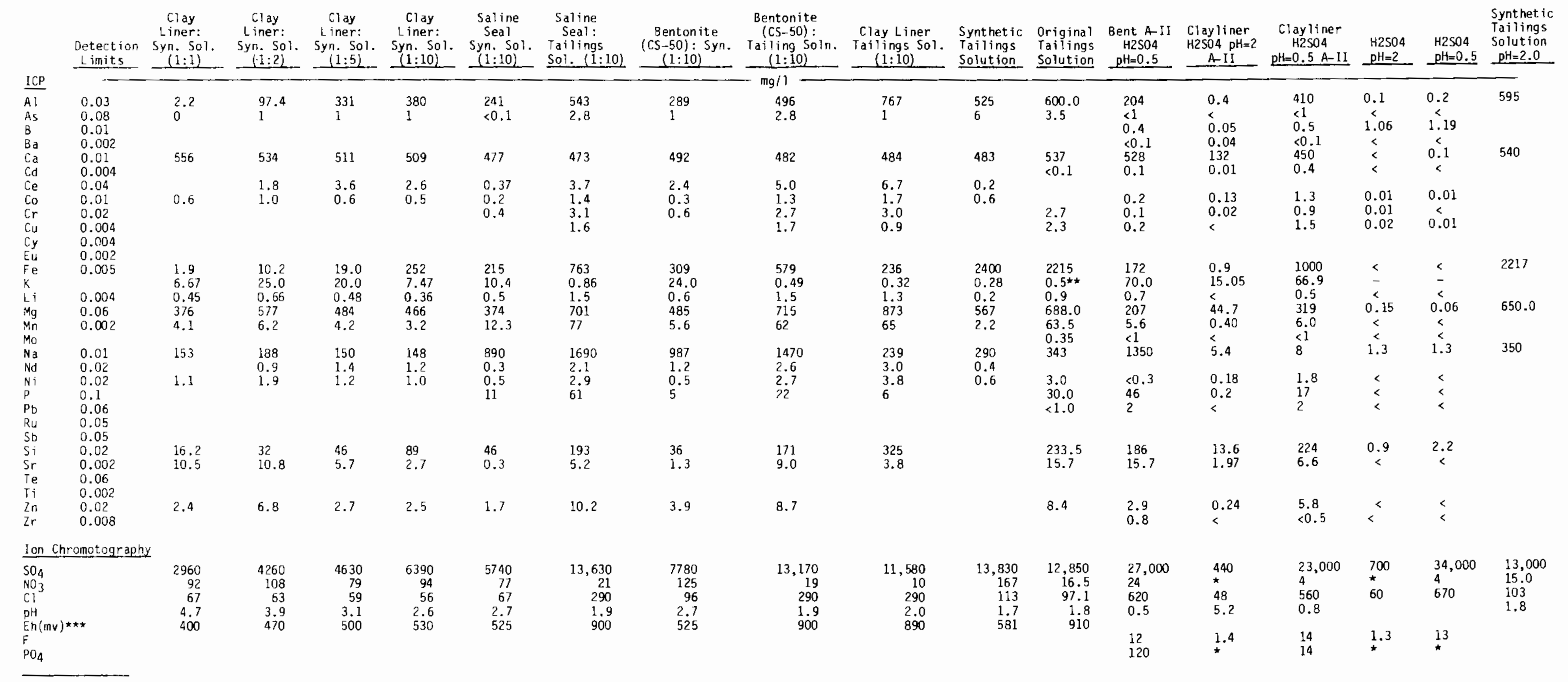

$\approx$ Just detect able.

** A minimal value, input for computational purposes.

$<$ elow detection limit.

- Not determined. 

TABLE 5.2. Chemical Analyses of Erfluent Solutions from Permeability Columns I and 5 which Contained the Morton Ranch Clay Liner Material Reacted with Synthetic and H.M. Tailings Solutions, Respectively

Leachate Samples $(\mathrm{mg} / \mathrm{l})$

\begin{tabular}{|c|c|c|c|c|c|c|c|c|c|c|c|c|c|c|}
\hline \multicolumn{7}{|c|}{ Column 1} & \multicolumn{8}{|c|}{ Column 5} \\
\hline Pore Volume & 1.26 & 2.12 & 2.95 & 4.47 & 5.89 & 25.51 & 1.35 & 3.46 & 5.54 & 6.24 & 7.91 & 8.89 & 10.39 & 11.17 \\
\hline \multicolumn{15}{|l|}{ Element } \\
\hline Al & $O L^{(a)}$ & $\mathrm{DL}$ & $\mathrm{DL}$ & 29 & 193 & 958 & OL & $\mathrm{DL}$ & DL. & 47 & 167 & 392 & 564 & 703 \\
\hline As & $\mathrm{OL}$ & $\mathrm{DL}$ & $\mathrm{DL}$ & 0.5 & 3.1 & $\mathrm{OL}$ & $\mathrm{OL}$ & $\mathrm{DL}$ & $\mathrm{OL}$ & 0.6 & 0.7 & $D L$ & $\mathrm{DL}$ & $\mathrm{OL}$ \\
\hline $\mathrm{Ca}$ & 686 & 703 & 715 & 660 & 600 & 517 & 657 & 612 & 820 & 512 & 467 & 507 & 528 & 517 \\
\hline $\mathrm{Cd}$ & $\mathrm{DL}$ & DL & $D L$ & 0.4 & 1.1 & 0.7 & $\mathrm{DL}$ & $\mathrm{DL}$ & 0.2 & 0.4 & 0.9 & 0.8 & 1.0 & 1.0 \\
\hline $\mathrm{Cr}$ & OL. & $\mathrm{DL}$ & $\mathrm{DL}$ & 0.2 & 0.02 & 0.2 & $\mathrm{DL}$ & DL & 0.08 & 0.1 & 0.1 & 0.5 & 0.5 & 0.5 \\
\hline $\mathrm{Cu}$ & 0.02 & DL & 0.5 & $\mathrm{OL}$ & 0.2 & 0.2 & $\mathrm{DL}$ & $\mathrm{OL}$ & 0.09 & 0.1 & 0.2 & 0.2 & 0.3 & 0.3 \\
\hline $\mathrm{Fe}$ & DL & $\mathrm{DL}$ & $\mathrm{DL}$ & 645 & 1582 & 1510 & $\mathrm{DL}$ & $\mathrm{DL}$ & 127 & 538 & 950 & 1330 & 1560 & 1720 \\
\hline Li & $\mathrm{DL}$ & DL & 0.2 & 0.3 & 0.5 & $\mathrm{DL}$ & $\mathrm{DL}$ & 0.4 & 1.2 & 1.0 & 1.1 & 1.4 & 1.4 & 1.3 \\
\hline $\mathrm{Mg}$ & 360 & 405 & 689 & 1040 & 1127 & 813 & 203 & 519 & 1420 & 1554 & 1771 & 1738 & 1601 & 1420 \\
\hline Mn & 0.2 & 1.4 & 4.2 & 7.0 & 8.2 & 4.5 & OL & 2.4 & 41.2 & 64.4 & 89.6 & 101 & 101 & 96 \\
\hline Mo & $D L$ & DL & $\mathrm{DL}$ & $\mathrm{DL}$ & $\mathrm{DL}$ & OL & $\mathrm{DL}$ & DL & DL & $\mathrm{DL}$ & $\mathrm{DL}$ & DL & $\mathrm{DL}$ & $\mathrm{OL}$ \\
\hline $\mathrm{Na}$ & 229 & 248 & 315 & 364 & 415 & 334 & 158 & 283 & 424 & 308 & 296 & 332 & 329 & 319 \\
\hline $\mathrm{Ni}$ & $\mathrm{DL}$ & OL & 1.4 & 4.3 & 5.6 & 2.5 & 0.2 & 0.5 & 4.1 & 0.8 & 10.9 & 12.9 & 12.4 & 10.8 \\
\hline$P$ & $D L$ & DL. & $D L$ & 7.2 & 9.8 & 3.8 & $D L$ & $D L$ & 1.5 & 2.1 & 2.1 & 3.0 & 3.8 & 3.8 \\
\hline Po & $\mathrm{DL}$ & $\mathrm{DL}$ & $\mathrm{DL}$ & 1.2 & $\mathrm{DL}$ & 3.0 & $D L$ & DL & $D L$ & $\mathrm{DL}$ & 0.5 & 2 & 2 & 2 \\
\hline $\mathrm{Se}$ & $\mathrm{DL}$ & $\mathrm{DL}$ & $\mathrm{DL}$ & 0.8 & $\mathrm{DL}$ & 1.1 & $\mathrm{DL}$ & $\mathrm{OL}$ & $\mathrm{DL}$ & $\mathrm{DL}$ & DL & 1.6 & $? .1$ & 2.1 \\
\hline$\$ i$ & 7.2 & 7.2 & 6.8 & 27.8 & 45 & 51 & 3.2 & 7.2 & 15.2 & 23.2 & 28.8 & 40 & 43 & 45 \\
\hline $5 r$ & 14 & 16 & 27 & 30 & 27 & 3.9 & 14 & 19 & 38 & 32 & 31 & 31.3 & 25.3 & 19.0 \\
\hline Th & $\mathrm{DL}$ & $\mathrm{DL}$ & $\mathrm{DL}$ & 2.1 & 0.4 & 2.0 & DL & $\mathrm{DL}$ & 0.9 & 2.1 & 3.4 & 5.3 & 5.3 & 5.3 \\
\hline u & $\mathrm{OL}$ & $\mathrm{DL}$ & $\mathrm{DL}$ & 23.1 & $\mathrm{DL}$ & $D L$ & 0.4 & 0.56 & DL & $\mathrm{DL}$ & $\mathrm{DL}$ & 19.7 & 23.8 & 27.2 \\
\hline Zn & 0.5 & $\mathrm{DL}$ & 3.2 & 7.7 & 7.8 & 11.1 & 0.5 & 0.7 & 9.1 & 15 & 21 & 29.5 & 31.8 & 29.5 \\
\hline \multicolumn{15}{|l|}{ By Ion } \\
\hline \multicolumn{15}{|c|}{ Chromatography } \\
\hline $\mathrm{Cl}$ & 121 & 97 & 88 & 100 & 97 & 100 & 132 & 292 & 402 & 303 & 306 & 389 & 355 & 333 \\
\hline $\mathrm{SO}_{4}$ & 2445 & 2690 & 3833 & 7147 & 7984 & 12,200 & 2220 & 3704 & 7864 & 9492 & 12,192 & 13,900 & 14,800 & 10,100 \\
\hline $\mathrm{pH}$ & $\overline{7.72}$ & 7.75 & 7.80 & 4.02 & 3.82 & 3.35 & 8.20 & 8.00 & 4.80 & 4.20 & 3.80 & 3.53 & 3.70 & 3.47 \\
\hline Eh & 348 & 346 & 343 & 581 & 593 & 623 & 318 & 331 & 532 & 570 & 594 & 612 & 601 & 618 \\
\hline
\end{tabular}

(a) $\mathrm{DL}=$ Less than detection limit. 
of 14 eff luent solutions from these columns were modeled (Table 5.2). The number of pore volumes of effluent that had passed through a given column when the solution was sampled is indicated in Table 5.2.

The $\mathrm{pH}$ values used for the modeled solutions were those reported in Tables 5.1 and 5.2 as the $\mathrm{final} \mathrm{pH}$ values of the reacted solutions, original $\mathrm{pH}$ values of the unreacted solutions, and the measured $\mathrm{pH}$ values of the column effluents. There were no Eh values or $\mathrm{e}^{2+} / \mathrm{Fe}^{3^{+}}$ratios measured specifically in this study. The Eh values used were those obiained from leaching experiments where a pH-Eh dependence was observed when the same liners and solutions, as used in this study, were reacted.

\subsection{RESULTS AND DISCUSSION}

Disequilibrium indices ( $\log$ AP/K) computed by WATEQ3 and MINTEQ are given in Tables 5.3 and 5.4 , respectively, for those solids which are calculated to be near equilibrium with the analyzed solutions or are relevant to the results of the $x$-ray characterization of new phases formed from liner materials. In some entries in Tables 5.3 and 5.4, the disequilibrium index was not computed for a particular phase because one or more of its ionic constituents was not reported in the solution analyses.

\subsubsection{Solubility Controls for Iron}

The chemistry of $\mathrm{Fe}$ in uranium mill tailings is important for several reasons: 1) under reduced $\mathrm{O}_{2}$ concentrations, the $\mathrm{Fe}^{2+} / \mathrm{Fe}^{3^{+}}$redox couple may determine, to a large extent, the redox status of the tailings solutions; 2) the iron oxides may act as adsorption surfaces (Jenne 1968, 1977; Means et al. 1978); 3) oxidation of pyrite (FeS2) may cause acidification of the tailings solutions (Cherry et al. 1980); 4) iron-bearing precipitates may decrease the pemeability of the clay liner and thus retard seepage from the tailings impoundments (Gee et al. 1980, Langmuir and Riese 1981). Iron chemistry is complex; tne solubilities and crystallization sequence of various iron oxides are affected at times by such diverse factors as particle size and relative humidity (Murray 1979, Langmuir 1971), and reaction kinetics (Murray 1979, Langmuir 1969, Nordstrom, 1979). The solubility of Fe in soils is, in large measure, controlled by the low solubility of the oxides and hydroxides of $\mathrm{Fe}$ (III), with amorphic $\mathrm{Fe}(\mathrm{OH})_{3}$ usually forming an upper limit on the activity of $\mathrm{Fe}^{3+}$. The term "amorphic" refers to solids which show a minimal $X$-ray diffraction pattern (Jenne 1972). The structure of $\mathrm{Fe}(\mathrm{OH})_{3}$ (ferric hydroxide) ranges from the amorphic to the crystalline depending on the mode of formation and age. Chukhrovet al. (1973) gave the composition of the crystalline ferric hydroxide, ferrihydrite, as $5 \mathrm{Fe}_{2} \mathrm{O}_{3} \cdot \mathrm{9H}_{2} \mathrm{O}$. Nordstrom et al. (1979) found that the solubility of $\mathrm{Fe}$ in acid mine waters appeared to be controlled by $\mathrm{Fe}(\mathrm{OH})_{3}(\mathrm{~A}) \quad(A=$ anorphic; Nordstrom uses the term amorphous instead of amorphic).

In every case, in the batch studies, the Fe content of the tailings solution decreased substantially after contact with the clay, Saline Seal ${ }^{\mathbb{B}}$, and 
TABLE 5.3. Values of $\log$ AP/K Calculated by WATEQ3 for Batch Experiments (AP = Activity Product of Solid; $K=$ Solubility Product)

\begin{tabular}{|c|c|c|c|c|c|c|c|c|c|c|c|c|c|c|c|c|c|c|c|c|}
\hline Material & $\stackrel{\mathrm{AlOHSO}_{\mathrm{a}}}{\mathrm{O}}$ & Arlophane & Anhydrite & Celestite & $\begin{array}{l}\text { New Gypsum } \\
\log _{10} \mathrm{~K}-4.60\end{array}$ & $\mathrm{NinHP}_{4}$ & $\begin{array}{r}5102 \\
\left(A . M M_{1}\right) \\
\end{array}$ & $\begin{array}{c}\mathrm{Na} \\
\text { Jarosite } \\
\end{array}$ & $\begin{array}{c}k \\
\text { Jarosite }\end{array}$ & $\begin{array}{c}H \\
\text { Jarasite } \\
\end{array}$ & Strengite & Chalcedony & Cristobalite & Goethite & Quartz & Alunite & Kaolinite & Anglesite & Maghemite & 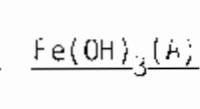 \\
\hline $\begin{array}{l}\text { Clay Liner/Synthet ic } \\
\text { Soln. } 1: 10\end{array}$ & 0.447 & -0.390 & 0.055 & -0.467 & 0.066 & - & 0.278 & -1.068 & 1.045 & -0.678 & - & 1.10 & 1.175 & 0.056 & 1.603 & -1.752 & -5.795 & - & -4.410 & -4.154 \\
\hline $\begin{array}{l}\text { Saline Seal/Synthetic } \\
\text { Soln. } 1: 10\end{array}$ & 0.348 & -0.704 & 0.023 & -1.426 & 0.035 & 0.337 & -0.009 & -0.193 & 1.285 & -0.682 & 1.174 & 0.813 & 0.888 & 0.191 & 1.316 & -1.602 & -6.161 & - & -4.641 & -4.026 \\
\hline $\begin{array}{l}\text { Bentonite/Synthet ic } \\
\text { Soin. } 1: 10\end{array}$ & 0.400 & -0.798 & 0.083 & -0.706 & 0.094 & -0.447 & $-0.10 y$ & 0.382 & 2.175 & -0.140 & 0.897 & 0.713 & 0.788 & 0.302 & 1.216 & -1.205 & -6.467 & - & -4.419 & -3.901 \\
\hline $\begin{array}{l}\text { Clay Liner/Tailings } \\
\text { Soln. } 1: 10\end{array}$ & 0.110 & 0.573 & 0.054 & -0.280 & 0.065 & -0.930 & 0.855 & 2.747 & 3.276 & 3.544 & 1.060 & 1.677 & 1.752 & 0.609 & 2.180 & -6.043 & $-\% .885$ & - & -3.805 & -3.603 \\
\hline $\begin{array}{l}\text { Saline Seal/Tailings } \\
\text { Soln. } 1: 10\end{array}$ & -0.156 & 0.452 & U.069 & -0.097 & 0.078 & -0.343 & 0.635 & 4.271 & 4.376 & 4.325 & 1.889 & 1.457 & 1.532 & 0.697 & 1.960 & $-6.78 ?$ & -9.374 & - & -3.628 & -3.515 \\
\hline $\begin{array}{l}\text { Bentonite/Tailings } \\
\text { Soln. } 1: 10\end{array}$ & -0.194 & 0.398 & 0.081 & 0.148 & 0.091 & -0.797 & 0.581 & 3.955 & 3.878 & 4.069 & 1.442 & 1.403 & 1.478 & 0.609 & 1.906 & -7.141 & -9.566 & - & -3.804 & -3.6013 \\
\hline $\begin{array}{l}\text { Clay Liner/Synthet ic } \\
\text { Soln. I:I }\end{array}$ & 0.342 & -0.751 & 0.036 & 0.032 & 0.048 & - & -0.469 & -1.528 & 0.530 & -3.274 & - & 0.353 & 0.428 & 2.095 & 0.856 & 4.37 & 1.214 & - & -0.8331 & -2.113 \\
\hline $\begin{array}{l}\text { Clay Liner/Synthet ic } \\
\text { Soln. } 1: 2\end{array}$ & 1.179 & -0.714 & 0.045 & 0.086 & 0.057 & - & -0.169 & -0.444 & 2.095 & -1.468 & - & $0.65 \%$ & 0.728 & 1.579 & 1.156 & 4.9603 & 0.130 & - & -1.866 & $-2.63 c$ \\
\hline $\begin{array}{l}\text { Clay Liner/Synthet ic } \\
\text { Soln. } 1: 5\end{array}$ & 0.899 & -0.726 & -0.004 & -0.243 & 0.008 & - & -0.013 & -3.045 & -0.506 & -3.170 & - & 0.809 & 0.884 & -0.029 & 1.312 & 1.661 & -3.237 & - & -5.681 & $-4 .<3 y$ \\
\hline $\begin{array}{l}\text { Bentonite } / \mathrm{H}_{2} \mathrm{SO}_{4} \\
1: 10 \mathrm{pH} 0.5\end{array}$ & -2.065 & 2.746 & -0.148 & 0.02 & -0.147 & -1.590 & 0.656 & -15.251 & -13.150 & -13.715 & -3.178 & $1.4 / 8$ & 1.553 & -6.940 & 1.981 & -14.447 & -18.036 & -0.250 & -18.047 & -11.150 \\
\hline $\begin{array}{l}\text { Clay Liner } / \mathrm{H}_{z} \mathrm{SO}_{4} \\
1: 10 \mathrm{pH} 0.5\end{array}$ & -1.411 & 2.173 & -0.090 & -0.207 & -0.085 & -2.568 & 0.719 & -13.087 & -8.771 & -9.017 & -3.076 & 1.540 & 1.615 & -5.280 & 2.043 & -11.754 & -15.716 & -0.198 & -15.580 & -9.494 \\
\hline $\begin{array}{l}\text { Clay Liner/ } \mathrm{H}_{2} \mathrm{SO}_{4} \\
1: 10 \mathrm{pH} 2.0\end{array}$ & -2.888 & -1.609 & -0.869 & -1.074 & -0.856 & - & -0.554 & 3.154 & 7.027 & 2.305 & - & 0.268 & 0.343 & 4.994 & 0.771 & -2.841 & -2.297 & - & 4.964 & 0.78 .4 \\
\hline $\begin{array}{l}\text { Original Acid } \\
\mathrm{H}_{2} \mathrm{SO}_{4} \mathrm{pH} 2.0\end{array}$ & -4.954 & -2.072 & - & - & - & - & -1.739 & - & - & - & - & -0.917 & -0.842 & - & -0.414 & - & -21.818 & - & - & - \\
\hline $\begin{array}{l}\text { Original } \mathrm{Acid} \\
\mathrm{H}_{2} \mathrm{SO}_{4} \mathrm{pH} 0.5\end{array}$ & -5.508 & 1.099 & -3.775 & - & -3.773 & - & -1.273 & - & - & - & - & -0.451 & -0.376 & - & 0.052 & - & -29.023 & - & - & - \\
\hline $\begin{array}{l}\text { Original Synth. } \\
\text { Soln. pH } 1.7\end{array}$ & -0.367 & - & 0.064 & - & 0.074 & - & - & -0.656 & -0.272 & 0.363 & - & - & - & -0.873 & - & -8.474 & - & - & -6.769 & - \\
\hline $\begin{array}{l}\text { Original Synth. } \\
\text { Soln. pH } 2.0\end{array}$ & -0.026 & - & 0.078 & - & 0.088 & - & - & -3.033 & - & -2.368 & - & - & - & -1.403 & - & - & - & - & -7.827 & -5.614 \\
\hline Golfinal Tajlings & -0.202 & 0.641 & 0.022 & 0.206 & 0.032 & -1.478 & 0.715 & 4.833 & 5.40 & 5.667 & 1.401 & 1.537 & 1.612 & 1.133 & 2.040 & -7.252 & -9.339 & -0.477 & -2.756 & -3.078 \\
\hline
\end{tabular}





\section{TABLE 5.4. Values of $\log A P / K$ Calculated by MINTEQ for Column Experiments}

( $A P=$ Activity Product of Solid; $K=$ Solubility Product $)$

\begin{tabular}{|c|c|c|c|c|c|c|c|c|c|c|c|c|}
\hline Perm Cell I & A $10 \mathrm{H} 50_{-4}$ & Anhydrite & \multicolumn{2}{|c|}{ e Celestite } & $\begin{array}{l}\text { New } \\
\text { Gypsum } \\
\log K= \\
-4.60\end{array}$ & $\mathrm{MnHPO}_{4}$ & $\begin{array}{c}\mathrm{Na} \\
\text { Jarosite }\end{array}$ & $\begin{array}{c}H \\
\text { Jarosite }\end{array}$ & Strengite & \multicolumn{2}{|c|}{ Chalcedony } & Eristobalite \\
\hline P.V. $=1.26$ & & 0.061 & 0.09 & & 0.023 & & & & & -0.0 & & 0.002 \\
\hline$P . y .=2.12$ & & 0.086 & -0.01 & & 0.048 & & & & & -0.0 & & 0.003 \\
\hline P.V. $=2.95$ & & 0.136 & 0.26 & & 0.098 & & & & & -0.0 & & -0.018 \\
\hline P. V. $=4.47$ & 0.376 & 0.035 & -0.49 & & -0.005 & 0.417 & 10.551 & 9.291 & 4.131 & 0.8 & & 0.905 \\
\hline P.y. $=5.89$ & 1.358 & 0.104 & 0.28 & & 0.064 & 0.7699 & 12.351 & 12.338 & 4.819 & 0.7 & & 0.821 \\
\hline P.V. $=25.51$ & 1.562 & 0.081 & -0.49 & & 0.040 & -0.630 & 10.860 & 10.417 & 3.655 & 0.81 & & $0.88 \mathrm{i}$ \\
\hline \multicolumn{13}{|l|}{ Ferm Cell 5} \\
\hline F.H. $=1.35$ & & 0.062 & -0.07 & & 0.024 & & & & -0.422 & & & -0.358 \\
\hline$H . \psi .=3.46$ & & 0.094 & 0.16 & & 0.056 & & & & & \multicolumn{2}{|c|}{-0.061} & 0.0030 \\
\hline$V_{1}=5.54$ & & 0.283 & 0.52 & & 0.243 & 2.260 & 11.806 & 9.805 & 4.406 & \multicolumn{2}{|c|}{0.283} & 0.347 \\
\hline $0.4 .=6.24$ & 1.090 & 0.108 & 0.49 & & 0.068 & 2.776 & 12.029 & 10.774 & 4.440 & \multicolumn{2}{|c|}{0.470} & 0.534 \\
\hline P.V. $=7.91$ & 1.217 & 0.091 & 0.51 & & 0.05 & 1,245 & 11.602 & 10.770 & 4.029 & \multicolumn{2}{|c|}{0.571} & 0.635 \\
\hline P.Y. $=8.89$ & 1.312 & 0.125 & 0.50 & & 0.083 & 0.676 & 11.274 & 10.664 & 3.559 & \multicolumn{2}{|c|}{0.718} & 0.782 \\
\hline P.V. $=10.39$ & 3.635 & 0.145 & 0.40 & & 0.104 & 0.826 & 11.979 & 11.204 & 3.765 & \multicolumn{2}{|c|}{0.751} & 0.815 \\
\hline P.Y. $=11.17$ & 1.507 & 0.004 & 0.06 & & -0.037 & 0.532 & 11.085 & 10.588 & 3.546 & \multicolumn{2}{|c|}{0.765} & 0.829 \\
\hline Perm Cell l & Quartz & Alunite & Koojinite & & glesite & Maghemite & $\underline{S i 0}\{A \mid$ & $\mathrm{Cu}(\mathrm{OH})_{2}$ & $\mathrm{Ni}(\mathrm{OH})_{2}$ & Zincite & Thoc ${ }_{2}$ & $-2 \mathrm{Fe}_{(\mathrm{OH})_{3}(\mathrm{~A})}$ \\
\hline$P . Y .=1.25$ & 0.421 & & & & & & -0.875 & -1.484 & & & & \\
\hline P.V. $=2.12$ & 0.422 & & & & & & & & & & & \\
\hline P.V. $=2.95$ & 0.401 & & & & & & -0.895 & -0.174 & -0.519 & -0.561 & & \\
\hline$P . V .=4.43$ & 1. 324 & 2.184 & 4.108 & & .108 & 5.683 & 0.028 & & -6.726 & -7.897 & 2.733 & 1.142 \\
\hline P.V. $=5.89$ & 1.240 & 4.090 & 4.226 & & & 5.931 & -0.056 & -7.213 & -7.955 & -8.244 & 0.431 & 1.265 \\
\hline P.V. $=25.51$ & 1.30 & 3.233 & 2.714 & & .010 & 3.957 & 0.004 & -8.194 & -9.279 & -9.087 & -0.017 & 70.278 \\
\hline \multicolumn{13}{|l|}{ Pencin Cell 5} \\
\hline P.V. $=1.35$ & 0.061 & & & & & & -1.235 & & -0.421 & -0.493 & & \\
\hline P.V. $=3.46$ & 0.422 & & & & & & -0.874 & & -0.605 & -0.858 & & \\
\hline$P . W .=5.54$ & 0.766 & & & & & 7.427 & -0.530 & -5.678 & -6.156 & 6.260 & 3.706 & 2.103 \\
\hline$P . V .=6.24$ & & 0.953 & 4.290 & & 363 & 6.385 & -0.343 & -6.817 & & -7.279 & 2.485 & 1.492 \\
\hline$P . V .=7.91$ & 2.054 & 3.420 & 3.113 & & $.88 \mathrm{i}$ & 5.248 & -0.242 & -7.350 & -7.791 & -7.995 & 1.734 & 0.923 \\
\hline P.H. $=8.89$ & 1.201 & 2.895 & 2.514 & & .185 & 4.457 & -0.095 & -7.895 & $-8.26 ?$ & & 1.589 & 0.527 \\
\hline P.V. $=10.39$ & 1.234 & 4.369 & 3.895 & & .183 & 5.262 & -0.062 & -7.383 & -7.941 & -8.030 & 1.830 & 0.930 \\
\hline P.V. $=11.27$ & 1.248 & 3.382 & 3.024 & & .226 & 4.422 & $-0,048$ & -7.839 & -8.463 & -8.457 & 1.903 & 0.510 \\
\hline
\end{tabular}


bentonite liner materials (see Table 5.1). The concentration of total dissolved $\mathrm{Fe}$ in the H.M. tailings solution was $2215 \mathrm{mg} / \mathrm{l}$. After contact, the dissolved Fe concentration varied from a high of $763 \mathrm{mg} / \mathrm{l}$ in the tailings solution reacted with the Saline Seal inaterial to a low of $236 \mathrm{mg} / \mathrm{e}$ in the tailings solutions after reaction with the clay iiner. The Fe content of the H.M. (original) tailings solution after 16 months of contact with the bentonite liner was reduced to $579 \mathrm{mg} / \mathrm{l}$. The original synthetic solutions at $\mathrm{pH}$ values of 1.7 and 2.0 had 2400 and $2217 \mathrm{mg} / \mathrm{e}$, respectively. Again, there was a reduction in total $\mathrm{Fe}$ concentration in every case after contact with the various liner materials. This would indicate that $\mathrm{Fe}$ has either precipitated out of solution or adsorbed onto the liner materials. The synthetic tailings solution was also reacted with the clay liner at the $1: 1,1: 2$, and $1: 51$ iner/solution ratios. As might be expected, higher liner/solution ratios removed greater amounts of $\mathrm{Fe}$ than did lower finer/solution ratios and also had higher $\mathrm{pH}$ values because of the buffering capacity of the liner material. The $\mathrm{H}_{2} \mathrm{SO}_{4}$ solutions at $\mathrm{pH}$ values of 2.0 and 0.5 had no detectable fe concentrations. After reaction with the liner at a 1:10 liner/solution ratio, the $\mathrm{H}_{2} \mathrm{SO}_{4}$ solutions had Fe concentrations that were $\mathrm{pH}$ dependent, with the lower $\mathrm{pH}$ solutions having the greater concentrations of Fe. Some degradation of the clay liner, dissolution of iron compounds, and/or desorption processes appear to occur in liner materials reacted with $\mathrm{H}_{2} \mathrm{SO}_{4}$ solutions, especially when the solutions are at low initial $\mathrm{pH}$ values. The caiculated $\mathrm{Fe}^{2+} / \mathrm{Fe}^{3^{+}}$ activity ratio varied from a high of 106.28 in the clay liner reacted with the synthetic tailings solution at a $1: 1$ ratio to a low of $10^{-2.49}$ in the original H.M. tailings solution, though the presumptive nature of the estimated Eh makes these values questionable.

The modeling results indicate a probable solid phase control on fe solubility in the batch experiments. The solubility of $\mathrm{Fe}(\mathrm{OH})_{3}(\mathrm{~A})$ may provide an upper bound on Fe solubility in these studies. All solutions resulting from contact with liner materials were undersaturated with respect to $\mathrm{Fe}(\mathrm{OH}) 3(\mathrm{~A})$, except the $\mathrm{H}_{2} \mathrm{SO}_{4}$ reacted with the clay liner at a $\mathrm{pH}$ of 2.0 , which was very slight ly oversaturated. This slight oversaturation may have been due to the fact that the rate of precipitation occurred more slowiy than the rate of pH change. The phincreased from 2.0 to 5.2 over a 7 -day reaction period. For each unit increase in $\mathrm{pH}$, there is a 1000-fold decrease in the $\mathrm{Fe}^{3+}$ activity maintained by ferric hydroxide. Alternately, the slight oversaturation could a] so be due to the speculative Eh value used in the modeling computations. Several of the solutions resulting from contact with liner materials computed to be oversaturated with respect to all other iron oxides and hydroxides except for maghemite $\left(r-\mathrm{Fe}_{2} \mathrm{O}_{3}\right)$ which was oversaturated in the $\mathrm{pH} 2$ suffuric acid solution as was $\mathrm{Fe}(\mathrm{OH})_{3}(\mathrm{~A})$. The maghemite was oversaturated to a greater degree than the amorphic ferric hydroxide. Murray (1979), quoting Schwertman and Thalman (1976), states that maghemite will not form at $\mathrm{pH}<6$. Thus, we wouid not expect to see maghemite in the acidic environments found in this study. The majority of the solutions were very oversaturated with respect to hematite $\left(a-\mathrm{Fe}_{2} \mathrm{O}_{3}\right)$ and goethite $(a-\mathrm{FeOOH})$, which are expected to control iron solubility only in a well drained highly weathered soil (Lindsay 1979). 
The column effluents behaved similarly to the batch experiments in that, in every sample, there was a decline in the effluent $F e$ concentrations from the influent concentrations with a strong inverse relationship existing between $\mathrm{pH}$ and the total $\mathrm{Fe}$ in solution. Above a $\mathrm{pH}$ of -6 , the solution $\mathrm{Fe}$ values were below the detection limits of the ICP.

All modeled column effluent solutions computed to be oversaturated with respect to $\mathrm{Fe}(\mathrm{OH})_{3}(\mathrm{~A})$. The degree of oversaturation was relatively constant, and small, and suggests the Eh values artificially imposed on the solution may have been slightly high. The effluent solution most oversaturated when compared to the $\mathrm{Fe}(\mathrm{OH})_{3}(\mathrm{~A})$ solubility product was the solution resulting from the leaching of the clay liner with the H.M. tailings solutions at a pore volume of 5.54. A reduction in the presumed $E$ h value of $<125 \mathrm{~m}^{V}$ would be enough to bring this solution into equilibrium with $\mathrm{Fe}(\mathrm{OH})_{3}(\mathrm{~A})$. This illustrates the importance of obtaining accurate Eh measurements when modeling solutions containing redox sensitive elements. Even with measured Eh values one must generally consider the values obtained to be of a qualitative rather than a quantitative nature.

The geochemical models (see Tables 5.3 and 5.4) computed all solutions, resulting from the interaction of H.M. tailings with clay liners, to be oversaturated with respect to $\mathrm{K}-, \mathrm{Na}-$, and $\mathrm{H}-$-jarosites $\left[\mathrm{KFe}_{3}\left(\mathrm{SO}_{4}\right)_{2}(\mathrm{OH})_{6}\right.$, $\mathrm{NaFe}_{3}\left(\mathrm{SO}_{4}\right)_{2}(\mathrm{OH})_{6}$ and $\mathrm{HFe}_{3}\left(\mathrm{SO}_{4}\right)_{2}(\mathrm{OH})_{6}$, respectively]. The liner materials contacted with the H.M. tailings solutions were the only reacted batch runs where all three jarosites were calculated to be oversaturated. The column effluent solutions were all oversaturated with regard to $\mathrm{Na}$ - and $\mathrm{H}$-jarosites. Because $\mathrm{K}^{+}$was not determined initially for the original H.M. tailings solutions or for the column eff luents, a minimal $\mathrm{K}^{+}$concentration of $0.5 \mathrm{mg} / \mathrm{l}$, which was representative of the lowest values for the other solutions, was added to the analyses to estimate the degree of saturation for K-jarosite. The original H.M. tailings solution and all column effluent solutions then computed to be oversaturated with all jarosites by several orders of magnitude. Jarosite was identified by $X$-ray diffraction in all batch experiments where H.M. tailings solutions reacted with the various liner materials. Pemeability cell 5 was divided into 5 equal, horizontal subsections and examined by $X-r a y$ diffraction. Jarosite was found in the subsection nearest the influent port in both the clay-sized fraction and the non clay-sized fraction. In the next subsection, jarosite was barely identifiable in the clay-sized fraction and could not be discerned in the non clay-sized portion of this subsection. In none of the other 3 subsections, farthest from the solution inf luent port, could jarosite be identified (see preceeding section on mineralogy).

Figure 5.1A was constructed using reactions and themodynamic data as originally tabulated in Ball et al. (1980) for WATEQ2. Plotted data points represent only the batch solutions. The indicated $\mathrm{SO}_{4}{ }^{2-}$ and $\mathrm{K}^{+}$activities on Figure 5.1A were used to calculate the reaction equilibria and were representative of those activities found in the actual batch solutions. At the pH values (1.9 to 2.0) of the H.M. tailings solutions, after reaction with the clay liners, jarosite could be precipitating from an $\mathrm{Fe}^{3+}$ activity controlled by $\mathrm{Fe}(\mathrm{OH})_{3}(\mathrm{~A})$. According to Figure 5.1A, K-jarosite would be stable in the 

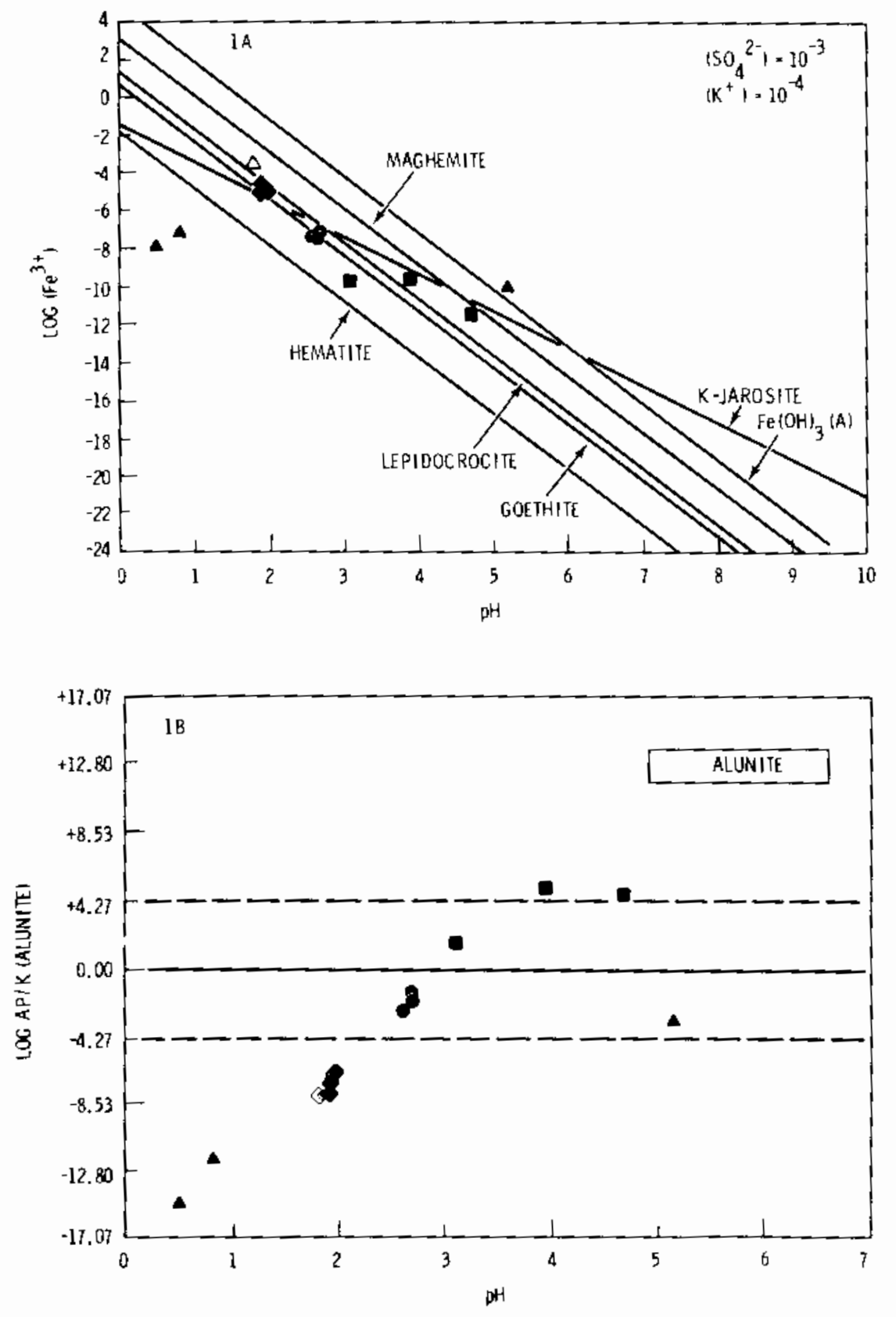

FIGURE 5.1. Stabilities of Various Fe-Containing Solids Plotted According to the Log of the Activity of $\mathrm{Fe}^{3+}$ Versus $\mathrm{pH}(1 \mathrm{~A})$, and Plot of the Log AP/K Versus pH for Alunite (1B). The open symbols and filled symbols are for the original and reacted solutions, respectively. The synthetic tailings solutions are represented by circles, the H.M. tailings solutions by diamonds, the synthetic tailings solutions from variable solid/solution experiments by squares, and $\mathrm{H}_{2} \mathrm{SO}_{4}$ solutions by triangles. 
presence of $\mathrm{Fe}(\mathrm{OH})_{3}(\mathrm{~A})$, at $\mathrm{pH}$ values less than $\sim 6$, which supports the modeling prediction that jarosite was precipitating in the presence of an Fe solublity controlled by $\mathrm{Fe}(\mathrm{OH})_{3}(\mathrm{~A})$. In the evaporative pond samples, jarosite was only identified in the upper part of the soil profile where the pH was $\leq 5.0$ (see section on mineralogy).

The fact that H.M. tailings solutions reacted with various clay liners, and the column effluent solutions, compute to be oversaturated with respect to the three jarosites suggest several possibilities: 1) kinetic constraints precluded the attainment of equilibrium; 2) organic complexes increased the quantity of dissolved constituents which enter into the activity product calculations of the jarosites; 3) the thermodynamic solubility products of the jarosites are orders of magnitude too low; and 4) thermodynamic data in WATEQ3 are for end-member compositions of jarosites, while the actual new precipitates determined by $X$-ray diffraction could have intermediate compositions. Possible organic complexation should be quite minor. Due to the low pH of the solution, any organic compounds should be fully protonated and thus unavailable for complexation. It is also extremely doubtful that the thermodynamic data would be in error by up to four orders of magnitude because of poor data or that the formation of intermediate compositions of jarosites, with greatly increased solubilities, is the cause for the observed supersaturation. It would, therefore, appear that there is a kinetic barrier which limits the rate of formation of the jarosites. As mentioned, jarosite was identified by $x$-ray diffraction and is precipitating, but the rate of precipitation is apparentiy too slow for the jarosites to be solubility controls for the elements involved.

Jarosite-supersaturation in acid solutions has been observed before by Nordstrom et al. (1979) and Langmuir and Riese (1981). Van Breemen and Harmsen (1975) noticed ferric hydroxide and jarosite deposition in acid sulfate sqits initially containing pyrite where the oxidation of the $\mathrm{Fe}$ in pyrite to $\mathrm{Fe}^{3+}$ occurred. From the foregoing discussion, it is thought that $\mathrm{Fe}(\mathrm{OH})_{3}(\mathrm{~A})$ provides an upper control on the solubility of Fe in the batch experiments, and possibly the column experiments, in these uranium mill tailings interacted with various liners. Ferric hydroxide was predicted to begin to precipitate around pH 2 in uranium mill tailings, by Langmuir and Riese (1981). This precipitation, as a slime, was thought to help reduce seepage away from the tailings impoundments. The precipitation of $\mathrm{Fe}(\mathrm{OH})_{3}(\mathrm{~A})$ and jarosite is likely contributing to the reduction in the concentration of $\mathrm{Fe}$ in reacted solutions and the reduced permeability that was observed when mill tailings solutions were leached through assorted clay liners.

\subsubsection{Solubility Controls for Calcium and Sulfate}

The modeled results of the batch experiments (Table 5.3) show that of the sixteen analyses where disequilibrium values for gypsum and anhydrite are computed, fourteen of these are in equilibrium with anhydrite $\left(\mathrm{CaSO}_{4}\right)$ while the remaining two solutions are undersaturated. Twelve of these analyses are slightly oversaturated with respect to gypsum $\left(\mathrm{CaSO}_{4} \cdot 2 \mathrm{H}_{2} \mathrm{O}\right)$. The sulfate concentrations in these solutions vary from $440 \mathrm{mg} / \mathrm{e}$ for the clay liner (Morton Ranch) reacted with $\mathrm{H}_{2} \mathrm{SO}_{4}$ to $27,000 \mathrm{mg} / \mathrm{e}$ for the bentonite reacted with $\mathrm{H}_{2} \mathrm{SO}_{4}$, 
with the maximum sulfate activity in solution being $1.567 \times 10^{-2} \mathrm{M}$. Sulfate concentrations tended to be $\mathrm{pH}$ dependent, with the lowest sulfate concentrations $(440 \mathrm{mg} / \mathrm{l}$ ) being associated with the highest $\rho H(5.2)$, and the highest sulfate concentrations $(27,000 \mathrm{mg} / \mathrm{l})$ occurring at the lowest $\mathrm{pH}(0.5)$. A similar pattern was observed in the modeled column effluents. Thirteen of the fourteen effluent solutions that were modeled were found to be in equilibrium with the anhydrite (Table 5.4) while the remaining solution was slightiy oversaturated with respect to this solid. All of the solutions, but one are oversaturated with respect to gypsum and the solution not oversaturated computed to be at equilibrium. The sulfate concentrations in these effluent solutions varied from a low of $2200 \mathrm{mg} / \mathrm{e}$ to a high of $14,800 \mathrm{mg} / \mathrm{l}$. The highest sulfate concentrations measured are close to the sulfate concentrations in the influent solutions. Again, a definite inverse relationship was noted between sulfate concentrations and $\mathrm{pH}$.

The calculated equilibria of these solutions with anhydrite, instead of gypsum, is somewhat of an enigma. Gypsum is not only thermodynamically more stable than the anhydrite at $25^{\circ} \mathrm{C}$ and 1 bar, but it is highly unlikely that the anhydrite could form in an aqueous environment. There are several possible explanations for the preferential equilibria with the anhydrite: 1) the high sulfate, low pH values could favor the anhydrite; 2) some sulfate complexes could be absent in the model, which if considered, would lower the sulfate activity; and/or 3) certain thermodynamic data in the model might be in error. oversaturation with respect to gypsum in uranium mill tailings has been previously computed by Langmuir and Riese (1981). The most likely explanation, at this time, for the oversaturation with gypsum is that the equilibrium constant for gypsum is too low. Tke $\log _{10} \mathrm{~K}$ (logarithm of the equilibrium constant at $25 \mathrm{C}$ ) for gypsum used in this model is -4.848 , while the log $10 \mathrm{~K}$ for anhydrite is -4.637 , both computed from the data originally tabulated in Robie and Waldbaum (1968). Gypsum has been found to be oversaturated in enough instances that a reevaluation of its equilibrium constant has been undertaken by D.K. Nordstrom of the U.S. Geological Survey. Nordstrom believes (personnal cormunication with E. A. Jenne, February 1981), from a perusal of gypsum solubility data, that the best value for the $\log _{10} K$ of gypsum is $-4.60 \pm$ 0.02 . All but three of the solution analyses compute to be in equilibriam with this new solubility constant for gypsum (see Tables 5.3 and 5.4 ). Whatever the correct value, this illustrates the potential of geochemical modeling to indicate particular themodynamic data that may be in need of reevaluation.

In the $X$-ray characterization study (preceeding section), no evidence of anhydrite or gypsum in the clay-sized fraction of the reacted or unreacted liner materials was found in the batch experiments. This could be due to an insufficient quantity of material for detection by $x$-ray powder diffraction and/or in the methods used in sample preparation for $x$-ray analysis. In the course of preparing these batch samples for analysis, the reacted and unreacted liner materials were contacted with large volumes of water for periods extending up to several days. This could have resulted in the dissolution of not only gypsum and anhydrite, but other solid phases as well. Gypsum was identi$f$ ied by $x$-ray diffraction in all 5 subsections of the dissected permeability cell (column 5) and was not found in the unreacted cell material. Column 5 
was packed with the Morton Ranch clay liner and reacted with the H.M. tailings solution. Gypsum was also found to increase in geologic materials at the Lucky Mc evaporation pond, after these materiais had been contacted with Lucky Mc tailings solution (see Section 4.0).

The X-ray characterization of the column and Lucky Mc field samples was done on bulk samples before the clay separation procedure had been performed. Gypsum, present in large quantity in the bulk samples, was not detected in the clay-sized fraction of these same samples, indicating that the clay separation procedure is probably responsible for the inability to identify gypsum in the clay-sized separates of the batch samples.

The $\mathrm{Ca}^{2+}$ and $\mathrm{SO}_{4}{ }^{2-}$ activities appear to be strongly controlled by either anhydrite or gypsum depending upon which equilibrium constants one accepts as being correct. The identification, by $X$-ray diffraction, of gypsum in the permeability column experiments gives some credence to our tendered explanation for the computed oversaturation with gypsum. That is, that the equilibrium constant for gypsum used in the models is too low. Figure 5.2A shows a plot of the $\log$ AP/K for the batch experiments using the new value of gypsum mentioned above. A very similar plot can be obtained if one plots the data from the column experiments. High concentrations of sulfate are known to severely limit the transport of radium (Landa 1980). The precipitation of gypsum (or anhydrite) could cause the coprecipitation of large amounts of radium through substitution of $\mathrm{Ra}^{2+}$ for $\mathrm{Ca}^{2+}$ in the gypsum (Shepherd and Cherry 1980).

\subsubsection{Solubility Controls for Aluminum}

Like iron, the aqueous geochemistry of the $\mathrm{Al}_{2} \mathrm{O}_{3}-\mathrm{SO}_{3}-\mathrm{H}_{2} \mathrm{O}$ system is complex because a variety of stable and metastable phases may form. Gibbsite $\left[\mathrm{Al}(\mathrm{OH})_{3}\right]$ and kaolinite $\left[\mathrm{Al}_{2} \mathrm{Si}_{2} \mathrm{O}_{5}(\mathrm{OH})_{4}\right]$ usually control the activity of aluminum in natural waters (Lindsay 1979), but the concomitant appearance of law $\mathrm{pH}$ values and high sulfate concentrations may alter this control. Knowledge of the controls on aluminum solubility in uranium mill tailings, reacted with geologic materials, is of consequence because it can denote secondary minerals that may be precipitating in the liner materials. Van Breenen (1973) observed that acid mine waters and samples from acid sulfate soils were consistantly undersaturated with respect to both gibbsite and kaolinite. Formation of secondary minerals in acid sulfate soils has been observed by Van Breeman (1976).

Dissolved aluminum concentrations varied considerably in the analyzed batch solutions. Values ranged from $2.2 \mathrm{mg} / \mathrm{s}$ aluminum in the synthetic solution reacted with the clay liner to $767 \mathrm{mg} / \mathrm{e}$ in the original tailings solution reacted with the same clay liner. The unreacted synthetic and the unreacted original tailings solutions had comparable initial concentrations of aluminum, 525 and $600 \mathrm{mg} / \ell$, respectively. The original tailings solutions, therefore, appear to have a greater capacity to maintain high concentrations of dissolved aluminum. In every case the original tailings solutions, after reaction with the various clay liners in batch experiments, supported a higher concentration 

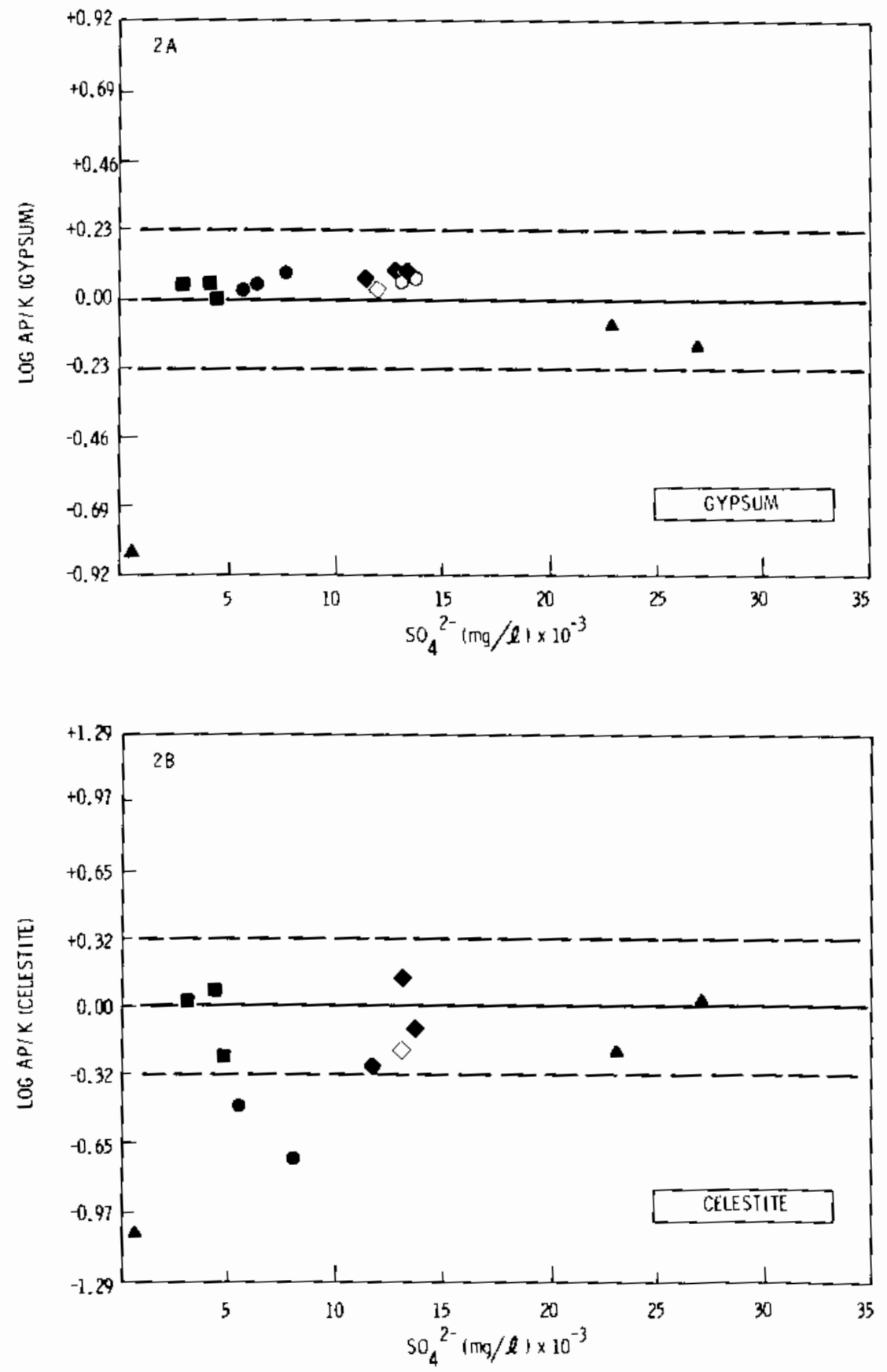

FIGURE 5.2. Plot of the Log AP/K Versus Sulfate Concentration for Gypsum (2A) and Celestite (2B). Same symbol notation as Figure 5.1. 
of aluminum then did the synthetic tailings solutions contacted with these same clay liners. The dissimilarity in aluminum concentrations between the original and synthetic tailings solutions $c$ an, at least in part, be explained by the consistently lower pH values encountered in the original tailings-batch solutions. There was a strong inverse relationship between $\mathrm{pH}$ and aluminum concentration for the modeled solutions. In contrast to the steadily increasing aluminum concentration with decreasing $\mathrm{pH}$, the computed activity of $\mathrm{Al}^{3+}$ increased with decreasing $\mathrm{pH}$ until a $\mathrm{pH}$ of $\sim 4$ was reached and then remained fairly constant for $\mathrm{pH}$ values lower than 4 . A change in the slope of the aqueous activity of $\mathrm{A}^{3+}$ versus $\mathrm{pH}$ line has been previously observed in acid mine waters (Crouse and Rose 1976). This change in the slope could possibly be due to transference of control from one solubility-controlling solid phase to another.

Aluminum concentrations in the analyzed column solutions also varied considerably, ranging from values that were below the detection limits $(0.03 \mathrm{mg} / \mathrm{l})$ up to a high of $958 \mathrm{mg} / \mathrm{R}$. The higher concentrations were encountered at the low $\mathrm{pH}$ values. At the lowest $\mathrm{pH}$ values, the effluent aluminum concentrations were higher than or approximated the influent concentrations.

Disequilibrium indices indicated several possible controls on aluminum solubility in the batch solutions. All of the solutions but one computed to be variably undersaturated with gibbsite, usually by several orders of magnitude. All batch solutions are near equilibrium or undersaturated with respect to alunite $\left[\mathrm{KA}_{3}\left(\mathrm{SO}_{4}\right)_{2}(\mathrm{OH})_{6}\right]$ (see figure 5.1b). The disequilibrium index for alunite, however, has quite a broad error band $(+4.2670)$ due to its large $\log _{10} \mathrm{~K}$. At high $\mathrm{pH}$ values, slight oversaturation with alunite is achieved, except at the highest $\mathrm{pH}(5.2)$, which is in equilibrium with alunite. These log AP/K values for alunite suggest that this mineral is an effective control on aluminum in the $\mathrm{pH}$ range 2.0 to 4.0 . Kaolinite could be controlling the upper limit of aluminum activity at pH values $>3.9$. Two of the solutions in this $\mathrm{pH}$ range are in equilibrium and one is undersaturated with respect to kaolinite. Alunite has been identified by $X$-ray diffraction in the reacted liner materials (see preceeding section on mineralogy). Moreover, Adams and Hajek (1978) have presented evidence to support the low temperature formation of alunite in acid sulfate soils.

It is plausible that a less soluble solid phase, such as $\mathrm{AlOHSO}_{4}$ (aluminum hydroxy sulfate), might control aluminum activity in the pH range 0.5 to 2.0. Breeman (1973) thought that a solid with the composition of $\mathrm{ATOHSO}_{4}$ controlled aluminum solubility in low pH, high sulfate waters. An $\mathrm{AlOHSO}_{4}$ control could account for the relatively constant aluminum activity at $\mathrm{pH}$ values below 4.0. Instead of the aluminum activity increasing with the increasing alunite solubility, as pH decreases, it could be suppressed by $\mathrm{AlOHSO}_{4}$. $\mathrm{AlOHSO}_{4}$ is less soluble than alunite in the pH range of 0.5 to 2.0.

It was impossible to specify a control on aluminum solubility in the column studies. All of the possible solubility controls on aluminum identified in the batch studies ( $\mathrm{A} 10 \mathrm{HSO}_{4}$, alunite, and kaOlinite) were oversaturated in every instance, in the column studies. The failure to attain equilibrium may 
be due to the shorter contact time of the solutions with the liner materiais, in the column studies, as compared to the batch experiments. The transit time of a pore volume of solution in the column studies was on the order of a few days and, therefore, considerably shorter than that of most of the batch studies.

Evidence, from both the WATEQ3 computed activity values and Figure 5.1B, suggests that different minerals may control aluminum solubility, in the batch studies, over the $\mathrm{pH}$ range encountered in this study. The proposed controls on aluminum activity in these uranium mill tailings are: 1) kaolinite at pH values above $\sim 4$; 2) alunite in the $\mathrm{pH}$ range $>2$ to $<4$; and 3 ) $\mathrm{AlOHSO}_{4}$ for those $p H$ values <2. The higher liner/solution ratios, the clay liner/synthetic soiution at $1: 1$ and $1: 2$ dilutions, were able to raise the $\mathrm{ph}$ of the tailings to a greater degree and thus come into equilibrium with kaolinite. Thus, liners with larger neutralizing capacities would be most likely to precipitate kaolinite from solution. No $X$-ray characterization studies were performed on those reacted clay liners that computed to be in equilibrium with kaolinite, though these same materials, before reaction with the solutions, did contain kaolinite.

\subsubsection{Solubility Controls for Strontium, Lead, Manganese, and Silicon}

Sufficient solution anaiyses were available to determine celestite $\left(\mathrm{SrSO}_{4}\right)$ disequilibrium indices for thirteen of the batch solutions (see Table 5.3 and Figure 5.2B). Nine of these solutions were in equilibrium with celestite while the remaining four were undersaturated. The high concentrations of sulfate in the batch solutions appear to make ceiestite an effective control on strontium solubility. Celestite also remained a possible control on strontium activity in the column experiments although the results were ambiguous. Four of the six modeled solutions resulting from leaching of the Morton Ranch ciay liner with synthetic tailings solutions were in equilibrium with solution activities controlled by celestite while the remaining two solutions were siightly undersaturated. In those effluents coming from the contact of the H.M. tailings solutions with the Morton Ranch clay liner, three of these solutions were in equilibrium with solution activities controlied by celestite while five were slightly oversaturated.

Sulfate concentrations also appear high enough for anglesite $\left(\mathrm{PbSO}_{4}\right)$ to exercise an effective control on lead solubilty. This is a very tentative conclusion as only two of the batch samples had a detectable quantity of dissolved lead, and these were in equilibrium with angiesite. The two solutions had $27,000 \mathrm{mg} / \mathrm{l}$ and $23,000 \mathrm{mg} / \mathrm{l}$ sulfate in solution. At a concentration of lead of oniy $2 \mathrm{mg} / \mathrm{l}$ even the lowest concentration of sulfate will majntain a sulfate activity adequate to determine lead solubility based on anglesite. Five of the six column effluent solutions for which PD data were available were found to be in equilibrium with solution activities controlled by anglesite. The sixth solution was undersaturated. The highest Pb concentration achieved in these column effluents was $3.0 \mathrm{mg} / \mathrm{l}$. 
A probable solid phase control of Mn activity in these synthetic and original uranium mill tailings solutions is $\mathrm{MnHPO}_{4}$. Of the eight batch solutions where $\mathrm{Mn}$ and $\mathrm{PO}_{4}$ determinations were obtained, three of these solutions were in equilibrium with $\mathrm{MnHPO}_{4}$ with the other solutions being undersaturated. $\mathrm{Mn}$ and $\mathrm{PO}_{4}$ concentrations were determined in nine column eff luent solutions and six of these solutions were in equilibrium with solution activities maintained by $\mathrm{MnHPO}_{4}$. The remaining eff luent solutions were oversaturated when compared to $\mathrm{MnHPO}_{4}$ solubility. $\mathrm{MnHPO}_{4}$ has been suggested as a possible Mn control for a variety of environments (Jenne et al. 1980). Although $\mathrm{MnHPO}_{4}$ has been discussed in the literature (Lindsay 1979), a cursory review of X-ray and mineralogical references has revealed no evidence for the occurrence of this mineral in natural soils.

Solubility relationships with silicon are often difficult to obtain (Lindsay 1979, quoting I1ler 1955) and no definite solubility control on silicon was established in this particular study. The batch solutions computed to be undersaturated with the most soluble phase of silicon dioxide $\left[\mathrm{SiO}_{2}(\mathrm{~A})\right.$, data from Morey et a1. 1964] at the highest $\mathrm{pH}$ values, in equilibrium at intermediate $\mathrm{pH}$ values, and oversaturated at $\mathrm{pH}$ values $<2$. The batch solutions were oversaturated with respect to other $\mathrm{SiO}_{2}$ minerals (e.g., quartz, cristobalite, and chalcedony) as were most of the column effluent solutions analyzed. The column solutions were all either in equilibrium or marginally undersaturated with $\mathrm{SiO}_{2}(A)$. The same tendency was shown in the column experiments as was manifest in the batch experiments, that is undersaturation with $\mathrm{SiO}_{2}$ (A) at the high $\mathrm{pH}$ values gradually progresssing to an equilibrium state as the pH was lowered. The column effluents did not reach the low pH values $(\mathrm{pH}<2)$ of the batch experiments. In both the batch and column experiments it would be tempting to speculate that $\mathrm{SiO}_{2}$ (A) controls silicon solubility were it not for the apparent $\mathrm{pH}$ dependence of silicon solubility. This $\mathrm{pH}$ dependence indicates that either a different type of soljd phase is controlling silicon solubility, such as an alumino-silicate, or there is an anomaly in the solution preparation and analysis that allow the results to vary with $\mathrm{pH}$ (Elgawhary and Lindsay 1972). It may also be that the solubility control is being transferred from one solid phase to another as the $\mathrm{pH}$ varies. The transference of the solid phase control could be explained by the following scenario. A part of the silicon in solution possibly comes from the dissolution of alumino silicates which tend to be unstable in acid solutions. In the more acid samples, this alumino-silicate dissolution could cause the $\mathrm{H}_{4} \mathrm{SiO}_{4}$ solution activity to rise until contralled by $\mathrm{SiO}_{2}(\mathrm{~A})$. At higher $\mathrm{pH}$ values, the precipitation of alumino-silicates such as kaolinite could lower the activity of $\mathrm{H}_{4} \mathrm{SiO}_{4}$ to levels below the solubility of $\mathrm{SiO}_{2}(\mathrm{~A})$. At higher $\mathrm{pH}$ values, the solubility of silicon would thus be controlled by kinetic (most alumino-silicate minerals form slowly), and not equilibrium considerations, while at lower pH values $\mathrm{SiO}_{2}(A)$ could exercise an effective control on silicon solubility.

\subsection{CONCLUSIONS}

The conclusions from the calculated results of the ion speciation-solubility portions of the WATEQ3 and MINTEQ geochemical models are: 
1. These geologic materials have the capacity to mitigate the solution concentrations of possible contaminants via precipitation reactions.

2. Solid phases, such as gypsum and $\mathrm{Fe}(\mathrm{OH})_{3}(\mathrm{~A})$, may be precipitating in the reacted liners and solutions resulting in decreases in the porosity and permeability.

3. Precipitation is observed to be a function of the liner/solution ratio with higher ratios having a tendency to precipitate more solids.

4. Higher liner/solution ratios have higher $\mathrm{pH}$ values which helps to explain the greater precipitation noted in conclusion 3.

5. Amorphic metastable solid phases may control the solubilities of their dissolved constituents $\left[\mathrm{e.g} ., \mathrm{Fe}(\mathrm{OH})_{3}(\mathrm{~A})\right.$ and $\left.\mathrm{SiO}_{2}(\mathrm{~A})\right]$.

6. Jarosites were computed to be supersaturated in the solutions resulting from the batch interaction of H.M. tailings solutions with all geologic and liner materials and in all the column effluents where adequate solution analyses were available, and were identified by $X$-ray diffraction in both the column and batch experiments.

7a. Solid phases identified as exercising possible controls on solution chemistry are $\left.\mathrm{Fe}(\mathrm{OH})_{3}(\mathrm{~A}), \mathrm{A}\right] \mathrm{HSSO}_{4}$, alunite, kalinite, celestite, anglesite, gypsum, $\mathrm{MnHPO}_{4}$, and $\mathrm{SiO}_{2}(A)$.

b. Solubilities of many elements and compounds were $\mathrm{pH}$ dependent (e.g., $\mathrm{Fe}, \mathrm{Al}, \mathrm{Si}$ and $\mathrm{SO}_{4}{ }^{2-}$ ).

8. For certain elements, such as Si and Al, different solubility controls may be operating at different $\mathrm{pH}$ values.

Certain solids identified as being in equilibrium with the solution chemistry were either poorly crystalline or present in such trace quantities that it would be impossible to identify their presence by $x$-ray diffraction.

It should be remembered that these results and conclusions represent an exploratory effort to geochemically model uranium mill tailings solutions, with their associated high suifate concentrations, low pH values, and high total dissolved solids. The results and conclusions are based on data from a limited set of experiments, and the solution analyses were modeled as reported, without judgement on the reported concentrations, even though the cation/anion imbalance exceeded $20 \%$ in several modeled solutions.

These modeling results illustrate the paramount importance of obtaining accurate and adequate solution analyses. They also demonstrate the importance of close collaboration of modeler and experimentalist so that analyses crucial to the modeling effort are performed. 
This exploratory use of geochemical modeling has demonstrated the ability of WATEQ3 and MINTEQ to test solubility hypotheses for the compositions of aqueous solutions that have high sulfate, low $\mathrm{pH}$ values, and high total dissolved solids, such as the acidic uranium mill tailings solutions. Modeling can also guide the selection of important constituents and parameters that should be analyzed in these solutions. It may also point to thermodynaric data that may be in need of reevaluation. Geochemical modeling $c$ an be used, in parallel with characterization techniques, to substantiate the presence or absence of solid phases in laboratory solubility studies. As used here, geochemical modeling is an effective tool in delineating the chemical causes for changes in permeability of clay liner materials. 



\subsection{CONCLUSIONS}

1. Various geologic materials have been proposed as hiners for uranium mill tailings impoundments. When acidic uranium mill tailings solutions encountered geologic materiais, containing over $30 \%$ clay, for periods up to 3 years; liner failure (i.e., an increase in permeability of the liner material) was not found to be a problem.

2. To achieve a minimum permeability and also minimize channel cracks and fracture flow, it is recommended that the liner be compacted to $90 \%$ of maximum compaction or greater, as determined by a standard proctor test.

3. A 1 m thick clay iiner with a calcium carbonate content of $4 \%$ or greater should not only be able to impede the pH front advance into the surrounding geologic material for hundreds of years, but should also be able, based on empirical evidence, to neutralize the total acidity contained in most tailings ponds over their active lifetimes.

4. Certain geologic materials contain a residual buffering capacity. This residual buffering capacity enables these materials to maintain columin effluent $\mathrm{pH}$ values at higher levels than the influent values, even after the initial buffering capacity of the soil has been exhausted.

5. Laboratory studies, geochemical modeling predictions, and fieid observations were found to complement one another. The iaboratory experiments and the geochemical modeling predictions were able to simulate the chemistry at an uranium mill tailings pond.

6. Liner materials meeting the above requirements will have the capacity to significantly mitigate the solution concentration of possible contaminants via precipitation and/or adsorption processes. Geochemical modeis can aid in quantifying the solution concentrations resulting from the interaction of acidic tailings solutions with clay liners.

7. Geochemical modeling predicts, and X-ray characterization work confirms, that given an adequate buffering capacity, precipitation of solids from solution should occur resulting in pore plugging and an uitimate reduction in the permeability of the liner materials.

8. Geochemical modeling can be used, in parallel with mineralogic characterization techniques, to delineate the chemical causes for changes in permeability of clay liner materials. 



\subsection{REFERENCES}

ASTM. 1978. Annual Book of ASTM Standards Part 19. American Society for Testing and Materials, Philadelphia.

Adams, F. and B. F. Hajek. 1978. "Effects of Solution Sulfate, Hydroxide, and Pot assium Concentrations on the Crystallization of Alunite, Basaluminite, and Gibbsite from Dilute Aluminum Solutions," Soil Sci. 126:169-173.

Ball, J. W., D. K. Nordstrom and E. A. Jenne. 1980. "Additional and Revised Thermochemical Data and Computer Code for WATEQ2 - A Computerized Chemical Model for Trace and Major Element Speciation and Mineral Equilibria of Natural Waters," U.S. Geologic Survey, Water Resources Investigations WRI-78-116, 109 pp.

Bal1, J. W., E. A. Jenne and M. W. Cantre11. 1981. "WATEQ3: A Geochemical Model with Uranium Added," U.S. Geological Survey, Hater Resources Investigations, (in press), $18 \mathrm{pp}$.

Black, C. A. 1965. Methods of Soil Analysis. Part 1. Physical and Mineralogical Properties Including Statistics of Measurement and Sampling. American Society of Agronomy Monograph 9.

Black, C. A. 1965. Methods of Soil Analysis. Part 2. Chemical and Microbiological Properties. American Society of Agronomy Monograph 9.

Breeman, N. Van. 1973. "Dissolved Aluminum in Acid Sulfate Soils and in Acid Mine waters." Soil Sci Soc. Am. Proc. 37:694-697.

Breeman, N. Van and K. Harmsen. 1975. "Translocation of Iron in Acid Sulfate Soils: I. Soil Morphology, and the Chemistry and Mineralogy of Iron in a Chromosequence of Acid Sulfate Soils." Soil Sci. Soc. Am. Proc. 39:1140-1148.

Breemen, N. Van. 1976. "Genesis and Solution Chemistry of Acid Sulfate Soils in Thailand," Agric. Res. Rep. 848, (Ph.D. Thesis), 263 pp.

Brindley, G. W., and G. Brown. 1980. "X-Ray Diffraction Procedures for Clay Mineral Identification." In Crystal Structures of Clay Minerals and Their X-Ray Identification, Mineralogical Society, London.

Cass, A., and M. E. Sumer. 1982. "Soil Pore Structural Stability and Irrigation Water Quality: II. Sodium Stability Data." Soil Sci. Soc. Am. J., $46: 507-512$.

Cherry, J. A., R. J. Blackport, N. Dubrousky, R. W. Gillham, T. P. Lim, D. Murray, E. J. Reardon and D. J. A. Smyth. 1980. "Subsurface Hydrology and Geochemical Evolution of Inactive Pyrite Tailings in the Elliot Lake Uranium District, Canada," Symposium on Uranium Mill Tailings Management, Fort Collins, Colorado, November 24-25. 
Cherry, J. A., T. A. Shepherd and K. A. Morin. 1982. Chemical Composition and Geochemic al Behavior of Contaminated Groundwater at Uranium TaiTings Impoundments. Presented at the SME-ATME Annual Meeting DalTas, Texas, February 14-18.

Chukhrov, F. V., B. B. Zoyagin, A. I. Gorshkov, L. P. Yermiloug and V. V. Balashova. 1973. "O Ferrigidrite (ferrihydrite)," An SSSR Izvestiya, ser. geo1. 23-33. Also (in English) Internat. Geo1. Rev. 16:1131-1143.

Crim, R. G., T. A. Shepherd, and 3. D. Nelson, 1979. "Stability of Natural Clay liners in a Low pH Environment," Proceedings of the Second Symposium on Uranium Mill Tailings Management. Civil Engr. Dept. Colo. State Univ., Ft. Collins, p. $41-53$.

Crouse, H. L. and A. Rose. 1976. "Natural Benification of Acid Mine Orainage by Interaction of Stream Sediment," 6th Symp. Coal Mine Drainage Res. NCA/BCR, Louisville, KY, 237:269.

Davies, C. W. 1962. Ion Association. Butterworths Pub., Washington 0.C. $190 \mathrm{pp}$.

Elgawhary, S. M. and W. L. Lindsay. 1972. "Solubility of Silica in Soils," Soit. Sci. Soc. Am. Proc. 36:4390442.

Erikson, R. L. and D. R. Sherwood. 1982. "Interaction of Acidic Leachate with Soil Minerals at Lucky Mc Pathfinder Mill, Gas Hills, Wyoming." Proceedings of the Fifth Symposium on Uranium Mill Tailings Management. Civil Engr. Dept. Colorado State University, Ft. Collins, Colorado. In Press.

Felmy, A. R., and E. A. Jenne. 1982. MINTEQ: A Computer Program for Calculating Aqueous Geochemical Equilibria, EPA-68-03-3089 (in press).

Gee, G. W., A. C. CampbelT, O. R. Sherwood, R. G. Strickert and S. J. Phillips. 1980a. "Interaction of Uranium Mill Tailings Leachate with Soils and Clay Liners," NUREG/CR-1494. Nationa? Technical Information Service, Springfield, Virginia.

Gee, G. W., A. C. Campbe11, B. E. Opitz and D. R. Sherwood. 1980b. "Interaction of Uranium Mill Tailings Leachate with Morton Ranch Clay Liner and Soll Material," Proceedings of the Third Symposium on Uranium Mill Tailings Management. Civil Engr. Dept. Colorado State University, Ft. Collins, Colorado, p. 333-352.

Heller-Kallai, L., and I. Rozenson. 1981. "Nontronite After Acid or Aikali Attack." Chemical Geology 32:95-102.

Iller, R. K. 1955. "The Colloid Chemistry of Silica and Silicates," Cornell University Press., I thaca, NY. 
Jackson, M. L. 1956. Soil Chemical Analysis--Advanced Course. Published by the author, Dept. of SoiTs, Univ. of Wis., Madison, Wisconsin.

Jackson, M. L. 1979. Soil Chemical Analysis--Advanced Course. 2nd Edition, lith Printing. Published by the Author, Madison, Wisconsin.

Jenne, E. A. 1968. "Controls on $\mathrm{Mn}, \mathrm{Fe}, \mathrm{Co}, \mathrm{Ni}, \mathrm{Cu}$, and $\mathrm{Zn}$ Concentrations in Soils and Water: The Significant Role of Hydrous Mn and Fe Oxides," In:

Trace Inorganics in Water, Adv. Chem. Series, No. 73, Am. Chem, Soc., Washington, D.C.

Jenne, E. A. 1977. "Trace Element Sorption by Sediments and Soi 1-Sites and Processes," p. 425-553. In: Symposium on Molybdenum in the Environment, Volume 2, W. Chappe1l and K. Peterson (eds), M. Dekker, Inc., NY.

Jenne, E. A. 1972. "Surface Charge Density Oependency on $\mathrm{Al}_{2} \mathrm{O}_{3}$ Content in Imogolite," Clays and Clay Minerals, 20:101-103.

Jenne, E. A., J. W. Ba!1, J. M. Burchard, D. V. Vivit and J. H. Barks. 1980. "Geochemical Modeling: Apparent Solubility Controls on $\mathrm{Ba}, \mathrm{Zn}, \mathrm{Cd}, \mathrm{Pb}$, and $F$ in Waters of the Missouri Tri-State Mining Area," In: 0. 0. Hemphill (ed.), Trace Substances in Environmental Health-XIV, University of Missouri.

Landa, E. R. 1980. "Isolation of Uranium Mill Tailings and Their Component Radionuclides from the Biosphere - Some Earth Science Perspectives," U.S. Geological Survey Circular 814, Arlington, Virginia.

Langmuir, D. 1969. "The Gibbs Free Energies of Substances in the System $\mathrm{Fe}-\mathrm{O}_{2}-\mathrm{H}_{2} \mathrm{O}-\mathrm{CO}_{2}$ at $25^{\circ} \mathrm{C}, "$ U.S. Geological Survey, Prof. Paper 650-B: $\mathrm{BI} 180-\mathrm{B} 184$.

Langmuir, D. 1971. "Particle Size Effect on the Reaction Geothite = Hematite and Water," Am. J. Sci. 271:147-156.

Langmuir, D., and A. C. Riese. 1981. "Geochemical Modeling of Radionuciides and Chemical Transport in Subsurface Waters: Application of Uranium Mill Tailings," p. A-34, Canadian Geological Meeting, Calgary, May.

Lindsay, W. L. 1979. "Chemical Equilibria in Soils," John Wiley and Sons, New York.

MacEwan, 0. M. C. 1961. "Montmorillonite Minerals." In The X-ray Identification and Crystal Structures of Clay Minerals, Mineralogical Society, London.

McNea 1, B. L., W. A. Norvell, and N. T. Coleman. 1966. "Effect of Solution Composition on the Swelling of Extracted Soil Clays." Soil Sci. Soc. Am. Proc. 30:313-317. 
Means, J. L., D. A. Crerar, M. P. Boresik and J. 0. Duguid. 1978. "Adsorption of $C_{0}$ and Selected Actinides by $M n$ and Fe Oxides in Soils and Sediments," Geochimica et Cosmochimica Acta. 42:1763-1773.

Morey, G. W., R. 0. Fournier, and J. J. Rowe. 1964. "The Solubility of Amorphous Silica at $25^{\circ} \mathrm{C}, " \mathrm{~J}$. Geophys. Res. 69:1995-2002.

Murray, J. W. 1979. "Iron Oxides," Chapter in Mineralogical Society of America, Short Course Notes, Volume 6, Novernber 1979, pp. 47-99, Roger G. Burns (ed.).

Nelson, R. W., A. E. Reisenauer, and 6. W. Gee. 1980. Model Assessment of Alternatives for Reducing Seepage of Contaminants from Buried Uranium MiTl Tailings at the Morton Ranch Site in Central Wyoming. PNL-3378, Pac if ic Northwest Laboratory, Richiand, Washington.

Nordstrom, D. K., E. A. Jenne and J. W. Ball. 1979. "Redox Equilibria of Iron in Acid Mine Waters," In: Chemical Modeling in Aqueous Systems.

E. A. Jenne (ed.), ACS Symposium Series No. 93:51-79.

O'Brien, F. E. M. 1948. "The Control of Humidity by Saturated Salt Solutions." J. Sci. Instrum. 25:73-76.

Relyea, J. F., and W. J. Martin. 1982. "Evaluation of Inactive Uranium Mill Tailings Sites for Liner Requirements: Characterization and Interaction of Tailings, Soil and Liner Materials." Proceedings of the Fifth Symposium on Uranium Mill Tailings Management. Civil Engr. Dept. Colo. State University, Ft. Collins, Colorado.

Robie, R. A., and D. R. Waldbaum. 1968. "Thermodynamic Properties of Minerais and Related Substances at $298.15^{\circ} \mathrm{K}\left(25.0^{\circ} \mathrm{C}\right)$ and One Atmosphere (1.013 bars) Pressure and at Higher Temperatures." U.S. Geological Survey, Bu]1. 1259.

Schwertmann, U., and $\mathrm{H}$. Thalman. 1976. "The Influence of $\mathrm{Fe}$ (II), Si and $\mathrm{pH}$ on the Formation of Lepidocrocite and Ferrihydrite During Oxidation of Aqueous $\mathrm{FeCl}_{2}$ Solutions," Clay Minerals II:184-204.

Sherard, J. L., L. P. Dunningan, and R. S. Decker. 1976. "Identification and Nature of Dispersive Soils." Am. Soc. Civil Eng. J., Geo-tech. Eng. Div. 101 (GT4).

Shepherd, T. A., and J. A. Cherry. 1980. "Contaminant Migration in Seepage from Uranium Tailings Impoundments: An Overview," Third Symposium on Uranium Mill Tailings Management, Fort Collins, Colorado, November 24-25.

Truesde 11, A. H., and B. F. Jones. 1973. WATEQ, A Computer Program for Calculating Chemical Equilibria of Natural Waters. NIIS-PB2-20464, Springfield, Virginia. 
U.S. Environmental Protection Agency. 1978. Hazardous Waste. Proposed Guidelines and Regulations and Proposal on Identification and Listing. Federal Register, 43(243):58946-59026.

U.S. Nuclear Regulatory Commission (USNRC). 1977. Final Environmental Statement Related to Operation of Lucky MC Gas Hills Uranium Mill. NUREG-0357, National Technical Information Service, Springfield, Virginia.

U.S. Nuclear Regulatory Commission (USNRC). 1979. Final Environmental Statement Related to Operation of Morton Ranch Uranium Mill, United Nuclear Corporation. NUREG-0532, National Technical Information Service, Springfietd, Virginia.

U.S. Nuclear Regulatory Comission (USNRC). 1980. Final Environmental Impact Statement on Uranium Milling. Project M-25. Sumary and Text. U.S. Nuc lear Regulatory Comission. NUREG-0706, Vol. 1.

Washington State Department of Social and Health Services, Radiation Control Section. 1980. Revised Draft: Environmental Impact Statement for the Proposed Dawn Mining Company Mill Tailings Expansion Project. Washington Department of Social and Health Services, OTympia, Washington.

Westa11, J. C., J. L. Zachary and F. M. M. Morel. 1976. MINEQL: A Computer Program for the Calculation of Chemical Equilibrium Composition of Aqueous Systems." Tech. Note 18, Dept. CiviT Eng., Massachusetts Institute of Technology, Cambridge, Massachusetts. 



\section{DISTRIBUTION}

No. of

Copies

A. A. Churn

DOE Patent Division

9800 S. Cass Avenue

Argonne, IL 60439

485 U.S. Nuclear Regulatory Commission

Division of Technical

Information and Document Control

7920 Norfolk Avenue

Bethesda, MD 20014

J. J. Davis

G. F. Birchard

NRC Off ice of Nuclear Regulatory Research

Washington, DC 20555

G. Gnugnoli

NRC Office of Nuclear Material

Safety and Safeguard

Washington, DC 20555
No. of

Copies

Mark Mathews

DOE Albuquerque Operations

$0 \mathrm{ff}$ ice

P.0. Box 5400

A7buquerque, NM 87115

ONSITE

46 Pacific Northwest Laboratory

R. L. Erikson (10)

A. R. Felmy

M. G. Foley

G. W. Gee (5)

K. M. Krupka

R. W. Nelson

S. R. Peterson (20)

L. C. Schwendiman

R. J. Serne

D. R. Sherwood

C. M. Unruh

N. J. Wogman

Publishing Coordination BE(2)

Technical Information (5) 


\begin{tabular}{|c|c|}
\hline $\begin{array}{l}\text { U.S. NUCLEAR AEGULATORY COMMISSION } \\
\text { BIBLIOGRAPHIC DATA SHEET }\end{array}$ & $\begin{array}{l}\text { 1. REPORT NUMEE R IAssigned oV DOC! } \\
\text { NUREG /CR-2946 } \\
\text { PNL } 4463\end{array}$ \\
\hline \multirow{2}{*}{$\begin{array}{l}\text { 4TITLE AND SUBTITLE (Add Volume No, if agpropriare) } \\
\text { The Long-Term Stability of Earthen Materials in Contact } \\
\text { with Acidic Tailings Solutions }\end{array}$} & 2. (Leave blank) \\
\hline & 3. AECIPIENT'S ACCESSION NO. \\
\hline S. R. Peterson, R. L. Erikson, G. W. Gee & \begin{tabular}{|l|l|} 
S. DATE REPORT COMPLETED \\
MONTH \\
OCtober & 1982 \\
\end{tabular} \\
\hline \multirow[t]{3}{*}{$\begin{array}{l}\text { 9. PERFORMING ORGANIZATION NAME AND MAILING ADOAESS IIMCIUde Zip Codel } \\
\text { Battelle Pacific Northwest Laboratory } \\
\text { Richland, WA } 99352\end{array}$} & 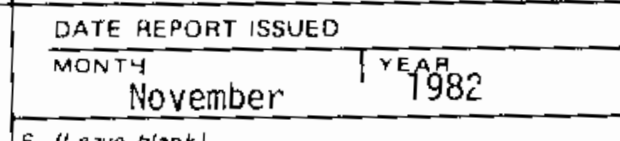 \\
\hline & 6. (theave blank) \\
\hline & 8. (Leave biank) \\
\hline $\begin{array}{l}\text { 12. SPONSORING OAGANIZATION NAME AND MAILING ADDRESS (thetude ZiO Codel } \\
\text { Division of Health, Siting, and Waste Management } \\
\text { Office of Nuclear Regulatory Research } \\
\text { U.S. Nuclear Regulatory Commission } \\
\text { Washington, DC } 20555\end{array}$ & \begin{tabular}{|c|} 
10. PHOJECT TASKIWOAK UNITNO \\
B2 FIN NO. \\
B2292
\end{tabular} \\
\hline \multicolumn{2}{|c|}{ 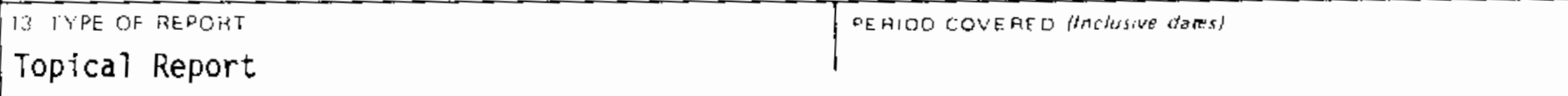 } \\
\hline 15. SUPPLEMENTAGY NOTES & 14. (Le eave diandik) \\
\hline \multicolumn{2}{|c|}{$\begin{array}{l}\text { The objectives of the studies documented in this report were to use experimental and } \\
\text { geochemical computer modeling tools to assess the long-term environmental impact of } \\
\text { leachate movement from acidic uranium mill tailings. Liner failure (i.e., an increase } \\
\text { in the permeability of the liner material) was not found to be a problem when various } \\
\text { acidic tailings solutions leached through liner materials for periods up to } 3 \text { years. on } \\
\text { the contrary, materials that contained over } 30 \% \text { clay showed a decrease in permeability } \\
\text { with time in the laboratory columns. The high clay materials tested appear suitable for } \\
\text { lining tailings impoundment ponds. The decreases in permeability are attributed to pore } \\
\text { plugging resulting from the precipitation of minerals and solids. This precipitation take } \\
\text { place due to the increase in pH of the tailings solution brought about by the buffering } \\
\text { capacity of the soil. Geochemical modeling predicts, and x-ray characterization confins, } \\
\text { that precipitation of solids from solution is occurring in the acidic tailings solution } \\
\text { liner interactions studied, In conclusion the same mineralogical changes and contaminant } \\
\text { reactions predicted by geochemical modeling and observed in laboratory studies were found } \\
\text { at a drained evaporation pond (Lucky Mc in wyoming) with a } 4 \text { year history of acid attack. } \\
\end{array}$} \\
\hline \multicolumn{2}{|l|}{$\begin{array}{l}\text { U KEY WORUS AVD DOCUMENT ANALYSIS } \\
\text { leanium mill tailings, Clay liners, } \\
\text { leachate migration }\end{array}$} \\
\hline \multicolumn{2}{|l|}{ 17t: IDENTIFIE US OPE WENDEU TEZMIS } \\
\hline \multirow{2}{*}{$\begin{array}{l}\text { B AVALILABILTY STATEME } \triangle T \\
\text { Unlimited }\end{array}$} & $\begin{array}{l}\text { CLASS iTh SePOOH } \\
\text { aSS. }\end{array}$ \\
\hline & 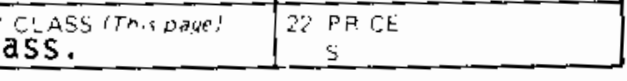 \\
\hline
\end{tabular}

$\triangle R C F O A Y 335 \quad \because{ }^{\circ}$ " 
